LAURO MASSAO WADA

Estudo do Comportamento de Solos Contaminados com Óleo de Isolamento de Transformadores

Dissertação apresentada à Escola Politécnica da Universidade de São Paulo para a obtenção do título de Mestre em Engenharia

- São Paulo -

2011 
LAURO MASSAO WADA

\section{Estudo do Comportamento de Solos Contaminados com Óleo} de Isolamento de Transformadores

Dissertação apresentada à Escola Politécnica da Universidade de São Paulo para a obtenção do título de Mestre em Engenharia

Área de Concentração:

Engenharia Geotécnica, Geotecnia Ambiental

Orientador: Prof. Dr. Marcos Massao Futai

- São Paulo - 


\section{Wada, Lauro Massao}

Estudo do comportamento de solos contaminados com óleo de isolamento de transformadores / L.M. Wada. -- São Paulo, 2011. 77 p.

Dissertação (Mestrado) - Escola Politécnica da Universidade de São Paulo. Departamento de Engenharia de Estruturas e Geotécnica.

1. Poluição dos solos 2. Fluxo de LNAPL 3. Modelo físico 4. HSSM I. Universidade de São Paulo. Escola Politécnica. Departamento de Engenharia de Estruturas e Geotécnica II. t. 
Dedicatória

Aos meus pais, pela paciência e incentivo para concluir esta etapa de minha vida.

À Vanessa, por me esperar. 
Agradecimentos

Aos professores da pós-graduação que ajudaram em minha formação acadêmica e como engenheiro geotécnico ambiental.

Aos amigos da pós-graduação, que sempre me fizeram a companhia ao longo do curso.

Aos técnicos de laboratório Joaquim e Antônio, com a ajuda nos ensaios e pela companhia diária.

Principalmente ao professor Marcos Massao Futai, pela paciência que teve comigo em todas as horas, me auxiliando não somente na vida acadêmica, mas em vários outros aspectos.

Ao CNPq e a FAPESP pelo auxílio financeiro. 
Índice

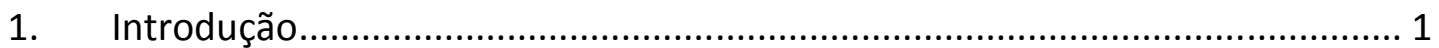

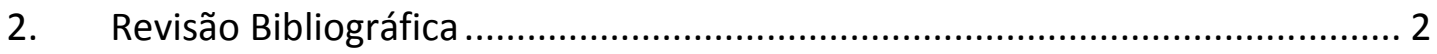

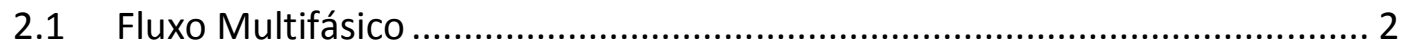

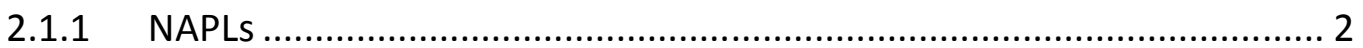

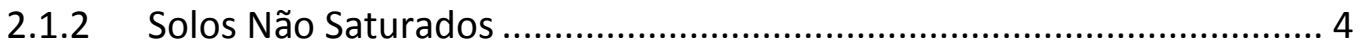

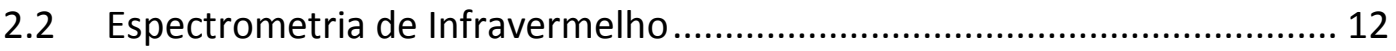

2.2.1 T.P.H. (Total Petroleum Hidrocarbon) .............................................. 12

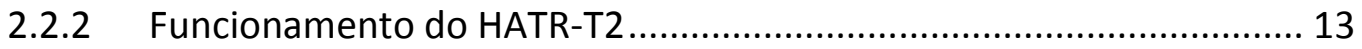

2.3 HSSM (Hydrocarbon Spill Screening Model) ............................................. 14

2.3.1 Kinematic Oily Pollutant Transport (KOPT)..................................... 15

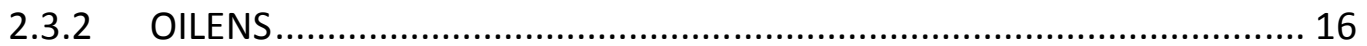

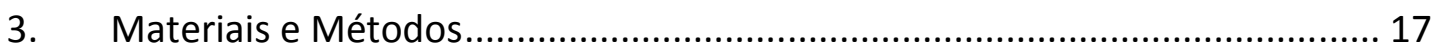

3.1 Ensaios de Laboratório ...................................................................... 17

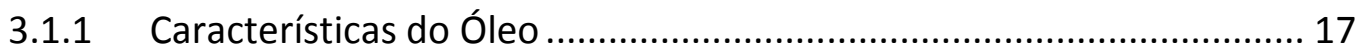

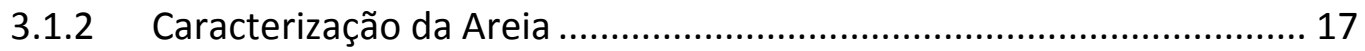

3.1.3 Curva Característica ...................................................................... 19

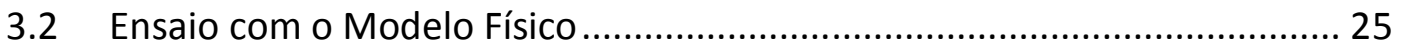

3.2.1 Ensaio de Derramamento de Óleo ................................................... 25

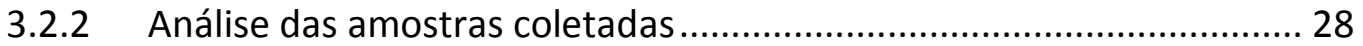

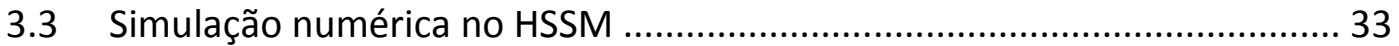

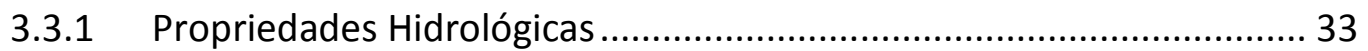

3.3.2 Propriedades do meio poroso ….......................................................... 35

3.3.3 Propriedades da fase de hidrocarbonetos ......................................... 36

3.3.4 Disposição do hidrocarboneto (NAPL) ............................................ 37 
3.3.5 Parâmetros de controle da simulação................................................. 38

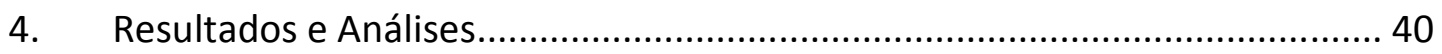

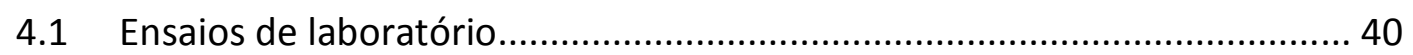

4.1.1 Curva de retenção matricial com água ............................................ 40

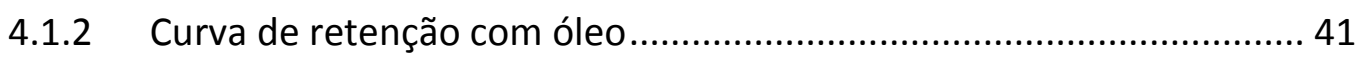

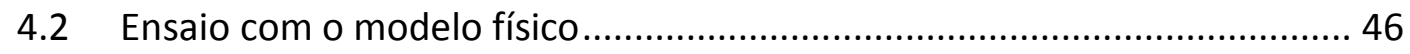

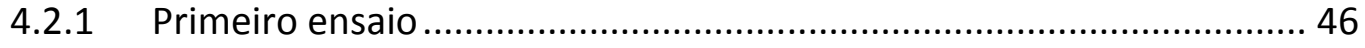

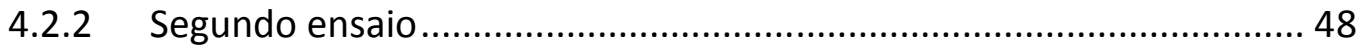

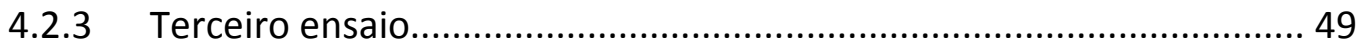

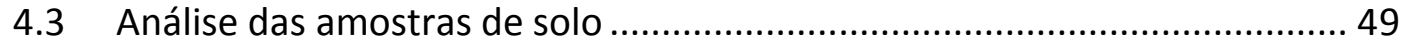

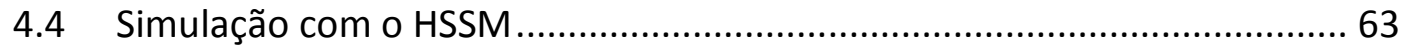

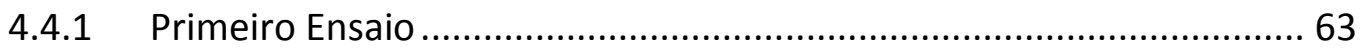

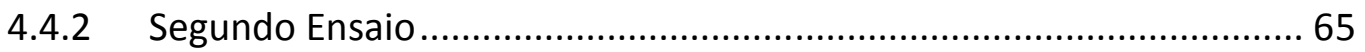

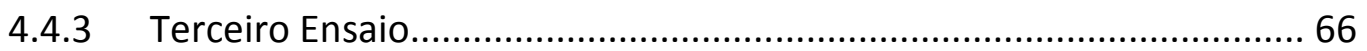

4.5 Comparação entre o modelo físico e o numérico......................................... 68

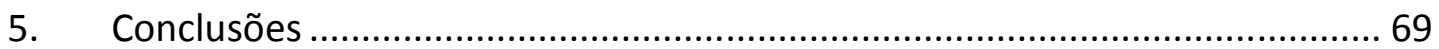

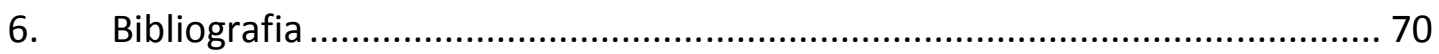


Figura 2.1 - Esquema da disposição do LNAPL no solo 3

Figura 2.2 - Esquema da disposição do DNAPL no solo............................................. 4

Figura 2.3 - Interação entre fases imiscíveis. (Adaptado de Fetter, 1999).................. 5

Figura 2.4 - Ascensão da água em tubo capilar. (Adaptado de Hillel, 1998)............... 7

Figura 2.5 - Ilustração da relação de sucção mátrica, osmótica e total. (Adaptado de Hillel, 1998). 8

Figura 2.6 - Curva de retenção de uma areia e um silte. 9

Figura 2.7 - Ilustração do efeito de "ink bottle". a) apresenta o caso em que a umidade está diminuindo; b) apresenta o caso em que a umidade está sendo elevada. (Adaptado de Hillel, 2003).

Figura 2.8 - Esquema da disposição de NAPL idealizado no programa HSSM (Modificado HSSM). 15

Figura 3.1 - Granulometria da areia de Itapetininga. 19

Figura 3.2 - Placa de sucção. a) vista geral do equipamento, b) placa de sucção com amostras, c) reservatório de água. 20

Figura 3.3 - Esquema da disposição do papel filtro (Vivian, 2009)........................... 21

Figura 3.4 - Processo de moldagem do corpo de prova........................................... 24

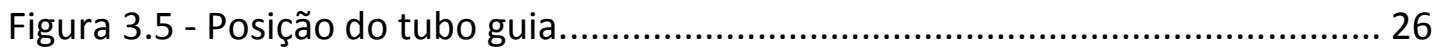

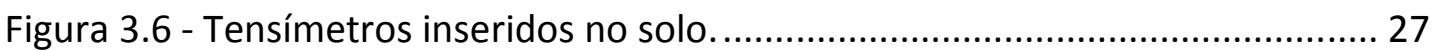

Figura 3.7 - Sistema de controle de nível d'água. ................................................. 27

Figura 3.8 - Analisador InfraCal TOG/TPH, com o detalhe da plataforma de cristal a direita 28

Figura 3.9 - Dados obtidos para a calibração do equipamento HATR-T2 ................... 30

Figura 3.10 - Pontos com suas respectivas linhas de tendência ............................. 31

Figura 3.11 - Imagem da janela para inserir os dados hidrológicos. ........................ 33

Figura 3.12 - Imagem da janela para inserir os dados da fase do hidrocarboneto... 36

Figura 3.13 - Imagem da janela para inserir dados para controle da simulação. ..... 38

Figura 4.1 - Curva característica da areia de Itapetininga..................................... 40

Figura 4.2 - Curva de retenção com 2\% de óleo. ..................................................... 41

Figura 4.3 - Curva de retenção com 5\% de óleo. 
Figura 4.4 - Curva de retenção com 10\% de óleo................................................. 42

Figura 4.5 - Curva de retenção com 15\% de óleo................................................... 43

Figura 4.6 - Comparação entre as curvas do recipiente cerâmico com as de vidro.. 44

Figura 4.7 - Início do derramamento de óleo......................................................... 46

Figura 4.8 - Disposição das amostras retiradas. ................................................... 47

Figura 4.9 - Retirada de amostras e armazenamento em recipientes de vidro com tampa.

Figura 4.10 - Parte inferior da pluma de óleo........................................................ 48

Figura 4.11 - Coleta de amostras no segundo ensaio............................................. 49

Figura 4.12 - Concentrações máxima e média de óleo em cada camada do primeiro ensaio.

Figura 4.13 - Concentrações máxima e média de óleo em cada camada do segundo ensaio. 55

Figura 4.14 - Concentrações máxima e média de óleo em cada camada do terceiro ensaio 56

Figura 4.15 - Concentração de óleo e a foto da camada 2 ...................................... 57

Figura 4.16 - Concentração de óleo e a foto da camada 3 ....................................... 58

Figura 4.17 - Concentração de óleo e a foto da camada 4 ......................................... 59

Figura 4.18 - Concentração de óleo e a foto da camada 5 ........................................ 60

Figura 4.19 - Concentração de óleo e a foto da camada 6 ....................................... 61

Figura 4.20 - Concentração de óleo e a foto da camada 7 ....................................... 62

Figura 4.21 - Parâmetros Hidráulicos da simulação do primeiro ensaio.................... 64

Figura 4.22 - Resultado da simulação do primeiro ensaio .........................................64

Figura 4.23 - Parâmetros Hidráulicos da simulação do segundo ensaio .................... 65

Figura 4.24 - Resultado da simulação do segundo ensaio..........................................6 65

Figura 4.25 - Lente de NAPL formada sobre o aquífero ........................................6 66

Figura 4.26 - Parâmetros Hidráulicos da simulação do terceiro ensaio ..................... 67

Figura 4.27 - Resultado da simulação do terceiro ensaio...................................... 67 
Índice de Tabelas

Tabela 3.1- Características do óleo AV-10.

Tabela 3.2 - Características da areia de Itapetininga.............................................. 18

Tabela 3.3 - Nomenclatura dos corpos de prova.................................................... 22

Tabela 3.4 - Peso de solo com água e/ou óleo de cada copo.................................. 22

Tabela 4.1 - Parâmetros da Curva de Retenção...................................................... 40

Tabela 4.2 - Parâmetros das curvas de retenção com óleo...................................... 43

Tabela 4.3 - Verificação da existência de gradiente de óleo no corpo de prova ...... 45

Tabela 4.4 - Resultado da análise das amostras do primeiro ensaio ........................ 50

Tabela 4.5 - Resultado da análise das amostras do segundo ensaio........................ 51

Tabela 4.6 - Resultado da análise das amostras do terceiro ensaio.......................... 53 


\section{Lista de Símbolos}

AbS - absorbância média.

e - índice de vazios.

n - parâmetro da equação de van Genuchten (1980).

S - grau de saturação.

$S_{w r}$ - saturação de água residual.

$\mathrm{V}_{\mathrm{T}}$ - volume total.

$\mathrm{V}_{\mathrm{w}}$ - volume de água.

w - umidade gravimétrica.

$\alpha$ - parâmetro da equação de van Genuchten (1980).

$\gamma_{w}$ - peso específico da água.

$\sigma_{S G}$ - tensão interfacial entre o sólido e o fluido não miscível.

$\sigma_{S L}$ - tensão interfacial entre o sólido e o fluido miscível.

$\sigma_{\mathrm{GL}}$ - tensão interfacial entre o fluido não miscível com o fluido miscível.

$\theta$ - umidade volumétrica.

$\theta r$ - umidade volumétrica residual.

$\theta$ s - umidade volumétrica saturada.

$\rho_{d}$ - densidade do solo seco.

$\rho_{\mathrm{w}}$ - densidade da água.

$\Psi$ - sucção. 


\section{RESUMO}

Com a finalidade de estudar o comportamento de fluidos aquosos não miscíveis em água no solo, foram executados ensaios de laboratório, a construção de um modelo físico e a comparação dos dados com a simulação numérica com o programa HSSM. Os ensaios de laboratório tiveram a finalidade de obter os parâmetros do solo utilizado no modelo físico e numérico. Foram obtidas curvas de retenção do solo com concentrações de 2, 5, 10 e 15\% de óleo e somente com água, para comparar o comportamento das curvas. Para o modelo físico, foi construído um tanque experimental para simular o derramamento de óleo no solo e, assim, obter uma pluma de contaminação de óleo de maneira controlada. Foram executados três ensaios com o tanque experimental, primeiro com o solo na umidade higroscópica, o segundo com um nível d'água definido, e o terceiro com o solo úmido, mas sem um nível d'água. Destes ensaios no tanque, foram coletadas amostras para a análise em laboratório das concentrações de óleo de cada parte do tanque.

A partir dos resultados das curvas características foi possível observar que o óleo influencia principalmente na umidade residual. E a análise das amostras coletadas do tanque experimental indica que a concentração de óleo na pluma estava constante, com concentração de $2 \%$ de óleo. Juntando os dados colhidos dos ensaios de laboratório e do tanque experimental, foram executadas simulações da evolução da pluma de contaminação de NAPL para os três casos simulados no tanque experimental. A simulação numérica foi coerente com o modelo físico, mas foi observado que subestima a velocidade de expansão da pluma, principalmente quando o solo está com a umidade baixa. 


\section{ABSTRACT}

In order to study the behavior of non-aqueous phased liquids in the soil, laboratory tests were performed, and the construction of a physical model and comparison of data obtained with the numerical simulation with the program HSSM. Laboratory tests are designed to obtain the soil parameters used in the physical and numerical model. Retention curves of soil with concentrations of $2,5,10$ and $15 \%$ of oil and water only were obtained to compare the curves. For the physical model, an experimental tankwas built to simulate the oil spill on the ground and have a contamination plume of oil with controlled conditions. Were performed three experiments with the tank, first with the hygroscopic soil moisture, the second with a defined water table, and the third with natural soil moisture, but without a water table. From these tests in the tank, samples were collected for laboratory analysis of concentrations of each part of the oil tank.

From the results of the retention curves it was observed that the major oil influence was on residual moisture. And the analysis of samples collected from the experimental tank indicates that the oil concentration in the plume was constant at the concentration of $2 \%$ of oil. Combining the data collected in laboratory testing and experimental tank, numerical simulations were performed of the evolution of NAPL contamination plume for the three cases simulated in the experimental tank. The numerical simulation was consistent with the physical model, but it was observed that underestimates the rate of expansion of the contamination plume, especially when the moisture of soil is low. 
1. Introdução

Com o avanço dos estudos sobre o meio ambiente, a contaminação do solo é uma das áreas que recebe grande destaque. Por isso, empresas com preocupações socioambientais e que tenham visão estratégica, se preocupam cada vez mais com os passivos ambientais, seja para evitar a criação de um novo passivo ou eliminar passivos existentes. Para isso são necessárias pesquisas sobre como detectar os poluentes e também sobre o comportamento dos mesmos nos solos.

O estudo realizado fez parte do Projeto de Pesquisa: Desenvolvimento de Metodologia e Diagnóstico Ambiental de Subestações de Energia Elétrica, que trata da avaliação do diagnóstico ambiental de Subestações (SEs) de Energia Elétrica para determinar locais com potencial contaminação do solo com óleos utilizados, principalmente em transformadores e em outros equipamentos. Também avaliar o passivo ambiental das atuais SEs da Concessionária Bandeirantes, ou seja, SEs com potencial de contaminação obtido inicialmente por inspeção visual ou por depoimentos de funcionários ou ex-funcionários de vazamentos ocorridos. Para uma empresa com preocupações socioambientais e com visão estratégica este projeto é essencial.

As SEs são locais com potencial de existir passivos ambientais. Os transformadores nela existente possuem um isolamento composto por óleo mineral. Este óleo (NAPL) está sujeito a derramamentos acidentais por falhas ou problemas na manutenção do transformador. Isso pode passar despercebido por longas datas, contaminando o solo, podendo atingir o aquífero, contaminando o mesmo. 


\section{Revisão Bibliográfica}

O estudo sobre o comportamento do óleo (NAPL - Non-Aqueous Phase Liquids) no solo necessita o conhecimento sobre diversos assuntos, principalmente sobre o fluxo multifásico, que por sua vez, pode ser dividida em várias partes. A seguir serão apresentados os conhecimentos básicos para a compreensão do comportamento do NAPL no solo.

\subsection{Fluxo Multifásico}

Para estudar o fluxo multifásico de um solo são necessários conhecimentos sobre o fluido não miscível (NAPL) e sobre os solos não saturados. Os itens a seguir descrevem sobre esses dois assuntos.

\subsubsection{NAPLs}

Os NAPLs (sigla em inglês para "Non-Aqueous Phase Liquids", que significa líquidos em fase não aquosa) são líquidos que existem em uma fase separada, não sendo miscível quando está em contato com o ar ou a água. Diferenças entre as propriedades físicas e químicas da água e do NAPL resultam na formação de uma interfase física entre os líquidos, impedindo a mistura entre eles. Os NAPL's podem ser classificados quanto à sua densidade. Se menos densos que a água, são chamados de LNAPL's (sigla em inglês para "Light non-aqueous phase liquids; líquidos leves em fase não aquosa), e se mais densos que a água, são chamados DNAPL's (sigla em inglês para "Dense nonaqueous phase liquids"; líquidos densos em fase não aquosa). A Figura 2.1 apresenta o esquema de disposição de um LNAPL. 


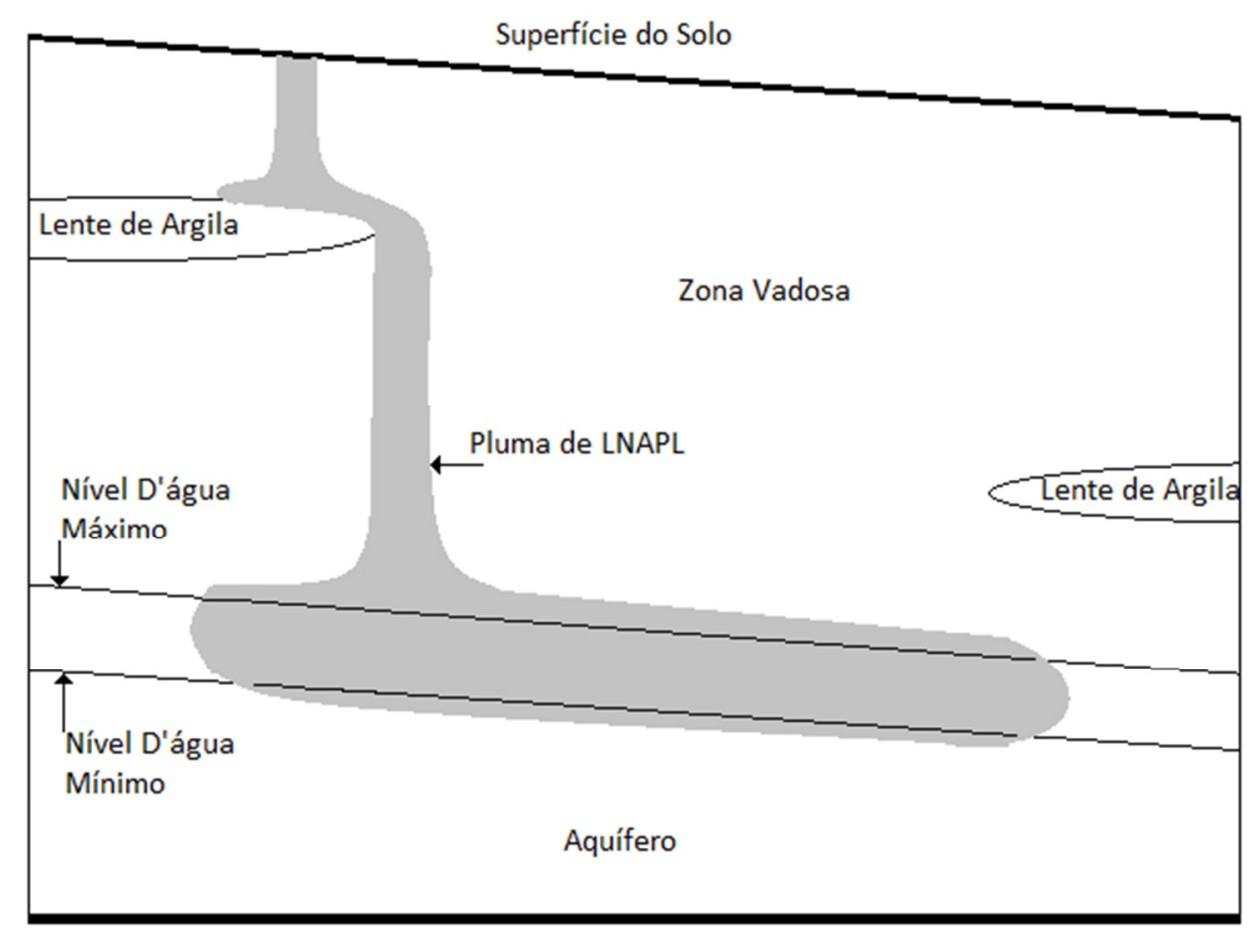

Figura 2.1 - Esquema da disposição do LNAPL no solo.

O movimento do LNAPL será comandado por vários fatores, incluindo a gravidade, pressão capilar, viscosidade, meio poroso, tensão interfacial, entre outros. No caso em que a disposição for de pouco volume, o LNAPL irá se mover na zona vadosa, onde ficará retido nas fraturas e poros do meio devido a forças capilares. No caso em que for disposto um volume suficiente, o movimento continuará até encontrar uma barreira física (no caso da Figura 2.1 é uma lente de argila) ou irá se movimentar até encontrar a influência do empuxo perto do nível da água. Atingindo o nível freático, o LNAPL tende a se acumular sobre o lençol freático, e no caso que haja volume suficiente, inicia-se o movimento lateral. Neste caso espera-se que o movimento siga a mesma direção do aquífero (Newell et. al., 1995, Castro Filho, 2007).

A pluma de LNAPL também pode se expandir na vertical devido à variação do nível da água. Quando o nível da água sobe, a pluma de LNAPL é empurrada para cima, deixando uma parte retida quando o nível voltar ao normal, ocorrendo fato semelhante quando ocorre o rebaixamento do nível da água (Newell et. al., 1995).

O comportamento do DNAPL é diferente ao do LNAPL quando a pluma atinge o lençol freático. Pelo fato de ser mais pesado que a água, o DNAPL começa a deslocar a 
água, e caso o volume de DNAPL seja suficiente, infiltra na zona saturada até atingir a base do aquífero (Fig. 2.2).

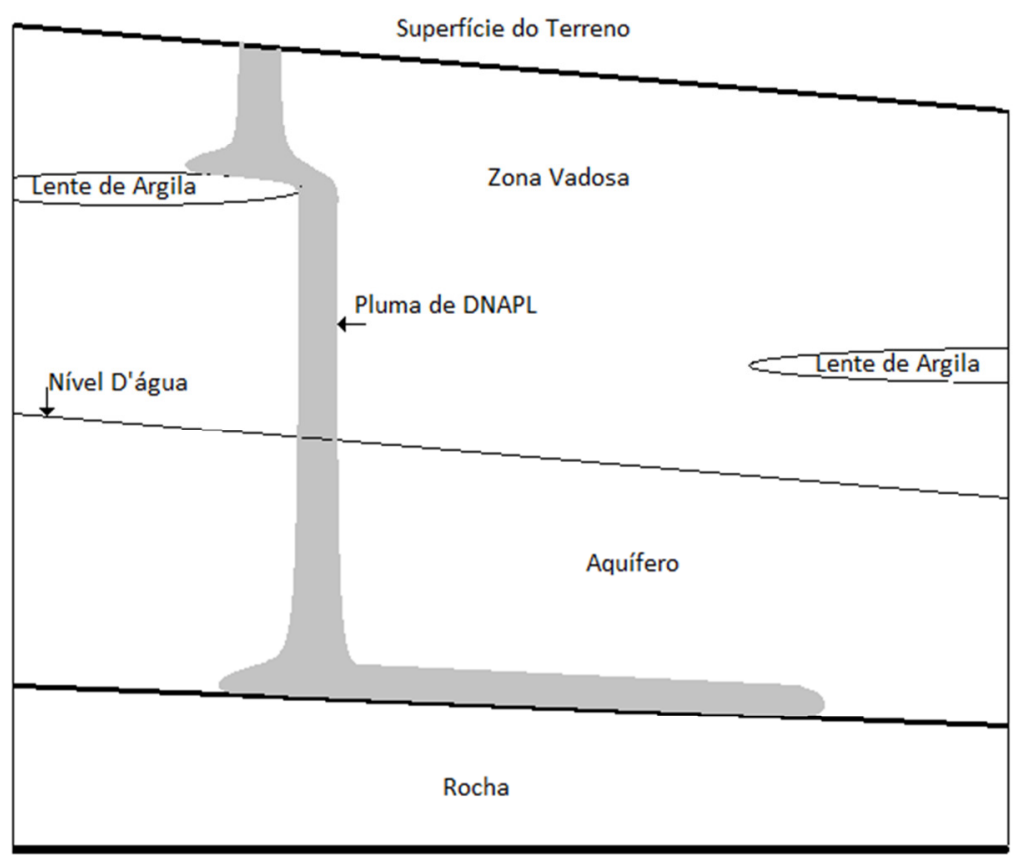

Figura 2.2 - Esquema da disposição do DNAPL no solo.

\subsubsection{Solos Não Saturados}

A importância de estudar os solos não saturados está no seu comportamento diferenciado em relação a um solo saturado. O fato do solo não estar saturado pode influenciar vários parâmetros geotécnico, como exemplo, condutividade hidráulica, resistência ao cisalhamento e variação volumétrica. Os itens a seguir apresentam conceitos que são necessários para entender o comportamento dos solos não saturados.

\subsubsection{Tensão Interfacial e Molhabilidade}

A tensão interfacial é definida como a quantidade de trabalho por unidade de área necessária para separar uma unidade de área de uma substância de outra. A unidade utilizada no S.I. é N/m. O valor da tensão interfacial entre a água e o ar, que neste caso é chamado de tensão superficial, é aproximadamente $73 \mathrm{mN} / \mathrm{m}$, para a temperatura ambiente. 
A tensão interfacial é causada pela diferença de coesão existente entre as moléculas de uma determinada fase com outra. Estas fases podem ser fluidos imiscíveis e sólidos. A Figura 2.3 apresenta um esquema de interação entre uma superfície sólida $S$, um líquido $L$ e outro fluido imiscível $G$, que pode ser um líquido ou um gás.

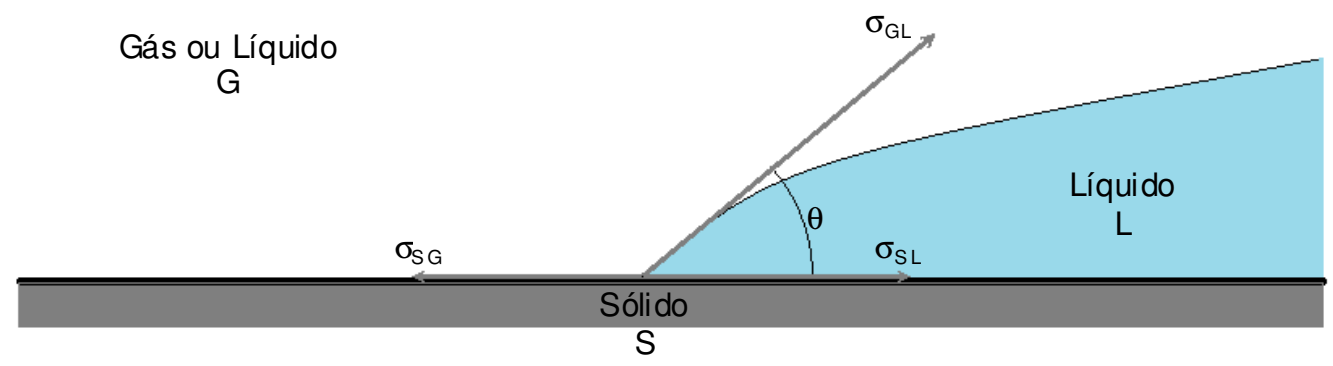

Figura 2.3 - Interação entre fases imiscíveis. (Adaptado de Fetter, 1999)

A relação entre as tensões $\sigma_{\mathrm{GL}}, \sigma_{\mathrm{SG}}$ e $\sigma_{\mathrm{SL}}$ está na Equação 2.1 abaixo:

$$
\cos \theta=\frac{\sigma_{S G}-\sigma_{S L}}{\sigma_{G L}}
$$

Onde:

- $\sigma_{\mathrm{GL}}$ é a tensão interfacial entre a fase $\mathrm{G}$ e a $\mathrm{L}$;

- $\sigma_{S G}$ é a tensão interfacial entre a fase $S$ e a G;

- $\sigma_{S L}$ é a tensão interfacial entre a fase $S$ e a L;

- $\theta$ é o ângulo de contato entre a fase L e G.

Por convenção, o $\theta$ é medido a partir do fluido mais denso. E com o ângulo de contato $\theta$ é possível classificar o fluido como molhante (wet), no caso em que o $\theta$ seja menor que $90^{\circ}$, e não-molhante no caso em que $\theta$ seja maior que $90^{\circ}$, sempre em relação à fase $S$. O fato de um fluido $L$ ser molhante em relação a outro fluido $G$, sobre a superfície $S$, significa que o fluido L terá preferência para cobrir a superfície $S$. 
Em um aquífero, é possível afirmar que a água sempre será o fluido molhante em relação aos óleos. Porém, em uma situação em que o solo foi molhado inicialmente por um óleo, o óleo permanecerá como o fluido molhante, caso a água não consiga entrar em contato com a superfície dos sólidos.

Existem casos onde o material sólido é hidrofóbico, tendo preferência a ser molhado pelo óleo. Nos trabalhos de Lenhard et al. (1988), Lenhard; Jonhson e Parker (1993), Lenhard (1992), Van Geel e Sykes (1994a), Van Geel e Sykes (1994b) e Kechavarzi; Soga e Illangasekare (2005) são utilizadas pedras porosas com tratamento para torná-la hidrofóbica, construindo um tensiômetro para o óleo. Por isso, não é correto afirmar que a água sempre será o fluido molhante. A molhabilidade sempre será uma propriedade determinada pelo conjunto das três fases.

\subsubsection{Pressão Capilar}

A pressão hidrostática da água em um solo é considerada como positiva quando sua a pressão é maior que a atmosférica. Quando a mesma é negativa, ou seja, a pressão é menor que a atmosférica, chamamos de sucção.

No solo, os poros entre os grãos formam canais de diâmetro muito reduzido que podemos relacionar como sendo um tubo de vidro de diâmetro muito reduzido, chamado de tubo capilar, apresentado na Figura 2.4 a seguir. A água ascende pelo tubo capilar até atingir a altura $\mathrm{H}_{2}$, sendo determinada pela fórmula abaixo:

$$
H=\frac{\pi \cdot r^{2} \cdot \gamma_{w}}{P}
$$

Onde:

$r$ = raio do tubo;

$\gamma_{w}=$ peso específico da água;

$\mathrm{P}=$ peso da água contida no tubo a partir da superfície livre.

Neste caso, a tensão interfacial entre a água e o ar, com a superfície sólida em contato sendo o vidro, será chamado de $\sigma$, e é responsável pela força (F) que faz a água ascender pelo tubo capilar:

$$
F=2 \cdot \pi \cdot r \cdot \sigma
$$


Igualando a força exercida pela tensão interfacial com o peso da água contida no tubo capilar temos a seguinte expressão:

$$
H=\frac{2 \cdot \sigma}{r \cdot \gamma_{w}}
$$

Observamos então que a ascensão capilar é inversamente proporcional ao raio da capilaridade.

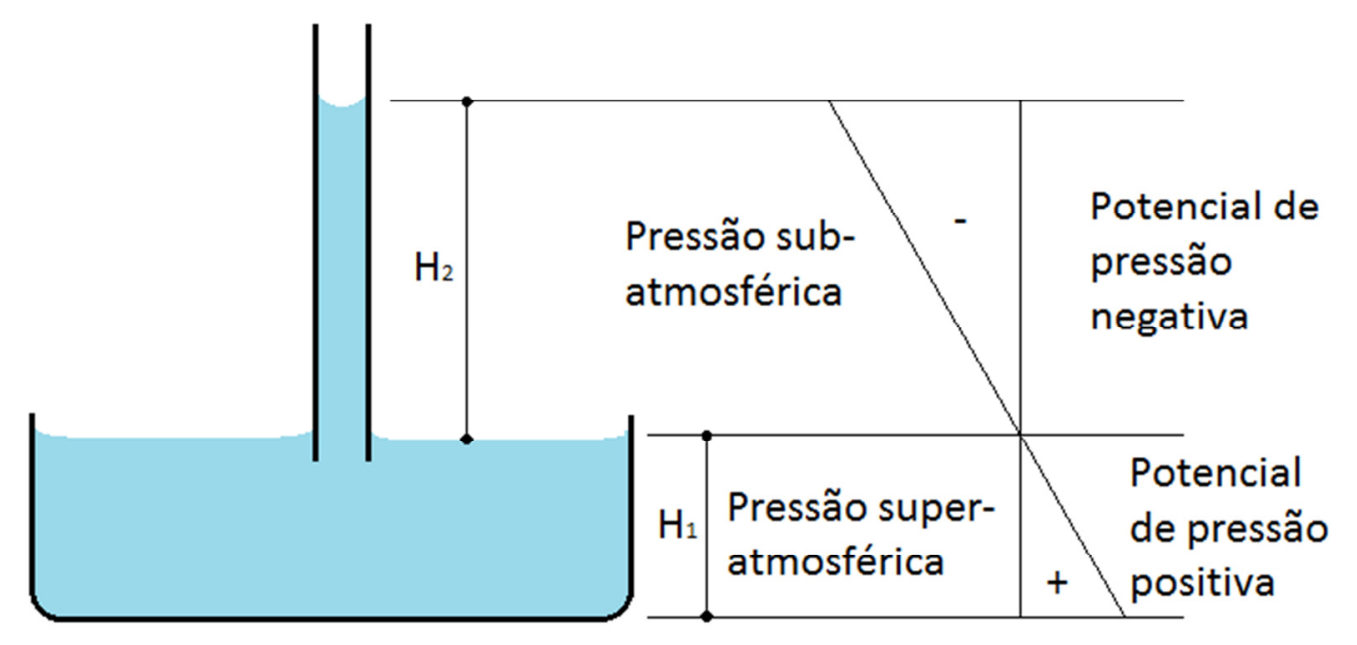

Figura 2.4 - Ascensão da água em tubo capilar. (Adaptado de Hillel, 1998).

\subsubsection{Sucção Mátrica, Osmótica e Total}

Quando a pressão capilar tem valor menor que a pressão atmosférica, chamamos de sucção. A sucção é dividida em dois componentes: mátrica e osmótica. A seguir será explicado cada tipo de sucção (Aitchison apud Marinho, 1997).

\section{Sucção Mátrica}

É a componente da sucção que é obtida através da medição da pressão parcial de vapor d'água em equilíbrio com a água intersticial, em relação a pressão parcial de vapor d'água em equilíbrio com uma solução com composição igual ao da água intersticial. 


\section{Sucção Osmótica}

A sucção osmótica é a obtida através da diferença de medição da pressão parcial de vapor d'água em equilíbrio com uma solução igual ao da água intersticial, com a medição da pressão parcial do vapor d'água em equilíbrio com água pura.

\section{$\underline{\text { Sucção Total }}$}

A soma da sucção mátrica com a sucção osmótica resulta na sucção total. Ou pode ser medida a partir da medição da pressão parcial de vapor d'água em equilíbrio com a água intersticial, em relação a pressão parcial de vapor d'água em equilíbrio com a água pura.

A Figura 2.5 apresenta o sistema que ilustra as relações entre as sucções.

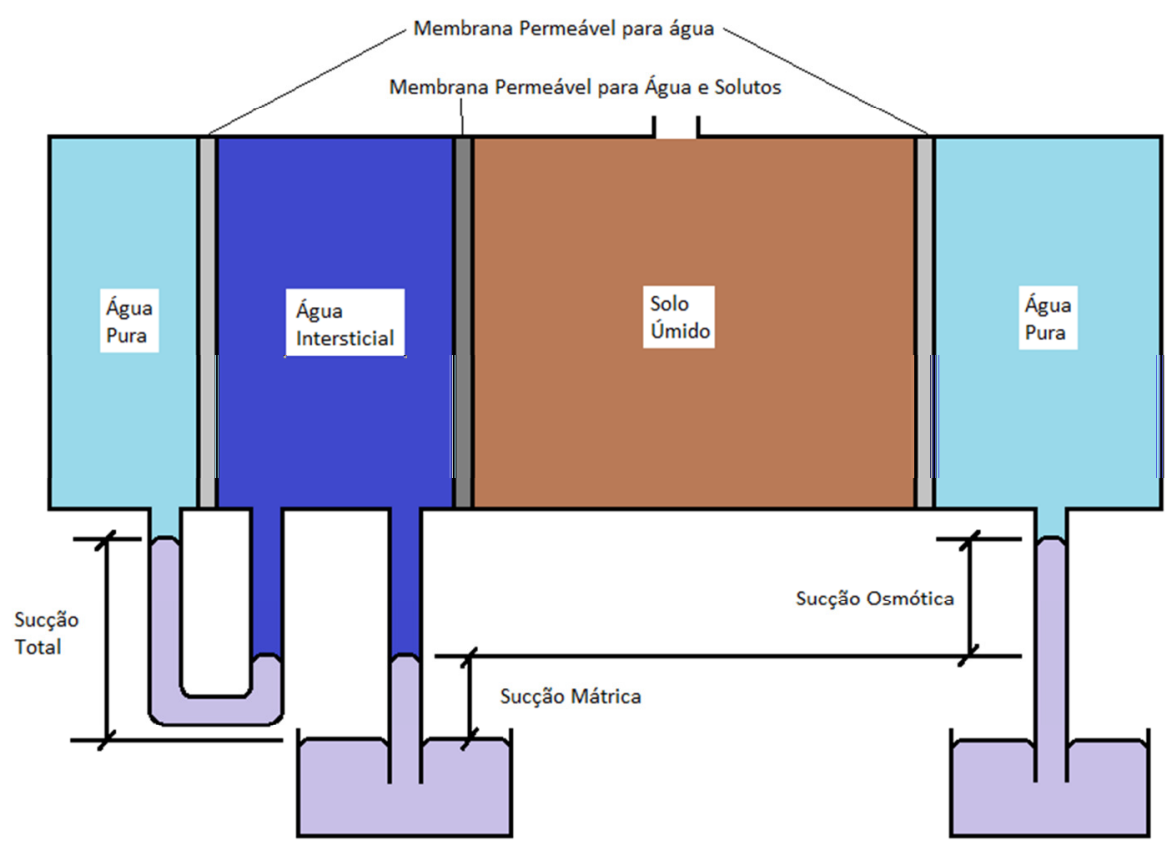

Figura 2.5 - Ilustração da relação de sucção mátrica, osmótica e total. (Adaptado de Hillel, 1998). 


\subsubsection{Curva de Retenção}

Quando é relacionado a pressão capilar (ou sucção) com a umidade volumétrica ou grau de saturação do solo, a curva resultante desta relação é chamada de curva de retenção ou curva característica de umidade do solo. A Figura 2.6 apresenta as curvas de uma areia e um silte.

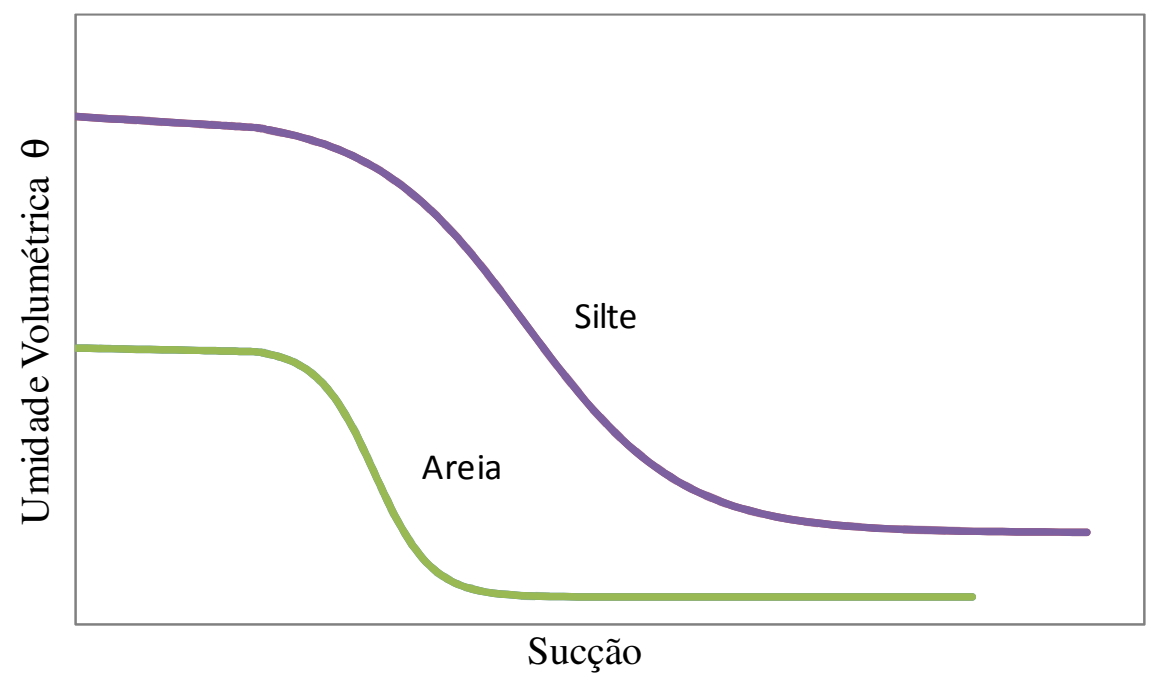

Figura 2.6 - Curva de retenção de uma areia e um silte.

A curva de retenção de um solo é obtida por ensaios de campo, utilizando tensiômetros, ou obtido por ensaios de laboratório, podendo ser citados os ensaios que utilizam a placa de sucção e os que utilizam o papel filtro.

O gráfico da curva de retenção pode ser apresentado de diversas maneiras, sendo as principais:

- Umidade gravimétrica (w) por Sucção;

- Grau de Saturação (S) por Suç̧ão;

- Umidade Volumétrica $(\theta)$ por Sucção.

Além dessas, existem várias outras maneiras de apresentar o resultado da curva característica. A seguir estão apresentadas as relações entre a umidade gravimétrica, grau de saturação e umidade volumétrica. 
$\theta=\frac{V_{w}}{V_{T}}=\frac{w \cdot \rho_{d}}{\rho_{w}}$

$\theta=\frac{S \cdot e}{1+e}$

Onde:

$\theta=$ umidade volumétrica;

$\mathrm{V}_{\mathrm{w}}=$ volume de água;

$\mathrm{V}_{\mathrm{T}}=$ volume total;

w = umidade gravimétrica;

$\rho_{\mathrm{d}}=$ densidade do solo seco;

$\rho_{\mathrm{w}}=$ densidade da água;

S = grau de saturação;

e = índice de vazios;

O método de representação da curva de retenção escolhida para este trabalho foi o qual utiliza a umidade volumétrica, pois possibilita a comparação dos resultados com as pesquisas já realizadas no laboratório da Escola Politécnica da USP.

Para obter parâmetros da curva de retenção, foi utilizado o modelo de Van Genuchten (1980):

$$
\begin{aligned}
& \Theta=\frac{\theta-\theta_{r}}{\theta_{s}-\theta_{r}} \\
& \Theta=\left[\frac{1}{1+(\alpha \Psi)^{n}}\right]^{m}
\end{aligned}
$$

Onde:

$\theta$ s = umidade volumétrica saturada; 
$\theta r=$ umidade volumétrica residual;

$\Psi$ = suç̧ão;

$\alpha, \mathrm{n}$ e $\mathrm{m}=$ parâmetros de ajuste.

Igualando as equações (2.7) e (2.8), obteve-se a equação (2.9):

$$
\theta=\theta_{r}+\frac{\left(\theta_{s}-\theta_{r}\right)}{\left[1+(\alpha \Psi)^{n}\right]^{m}}
$$

\subsubsection{Efeito da histereses}

$\mathrm{Na}$ execução dos ensaios para obtenção da curva de retenção em laboratório, é importante considerar o efeito de histereses, onde a curva de retenção passa por caminhos diferentes dependendo da maneira que a umidade da amostra foi modificada.

Segundo Hillel (2003), a causa do efeito de histereses pode ser atribuída a diversos fatores: a não uniformidade dos poros, podendo causar o efeito de "ink bottle" (Fig. 2.7); os diferentes ângulos de contato de avanço e recuo do menisco causado pela irregularidade da superfície; a retenção do ar em poros que possuem poucos canais de contato com outros poros; e o histórico de saturação do solo, que pode ter sofrido modificações ao longo do tempo.
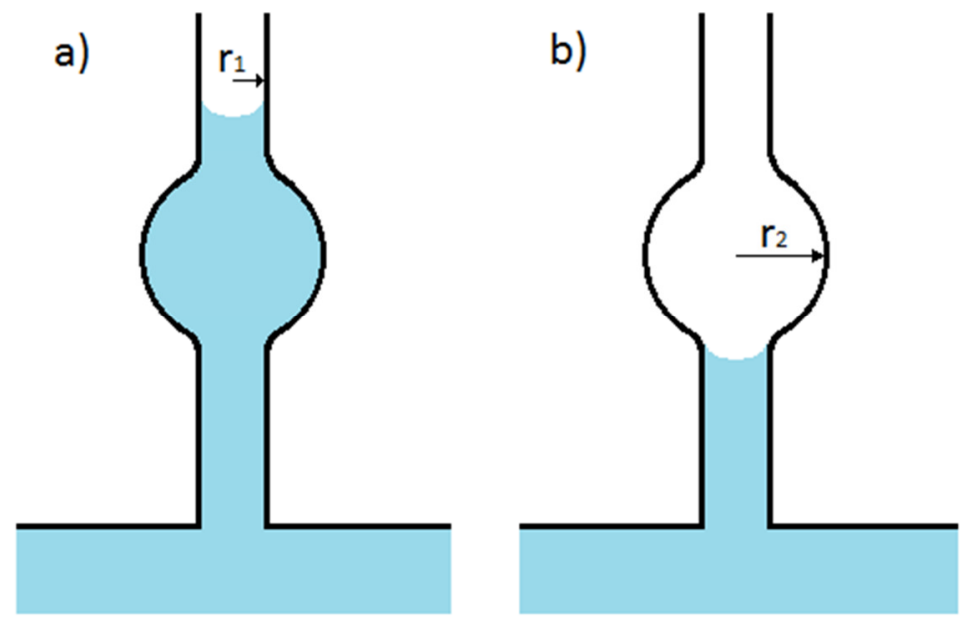

Figura 2.7 - Ilustração do efeito de "ink bottle". a) apresenta o caso em que a umidade está diminuindo; b) apresenta o caso em que a umidade está sendo elevada. (Adaptado de Hillel, 2003). 
O efeito "ink bottle" ocorre quando a força resultante da tensão interfacial é suficiente para sustentar a água em uma capilaridade de raio $r_{1}$, porém no meio dessa capilaridade existe um poro com o raio $r_{2}$, sendo $r_{2}$ maior que $r_{1}$. Para a situação em que o solo está em processo de diminuição da umidade a partir da saturação, o poro de raio $r_{2}$ permanece preenchido de água. Porém, no caso em que o solo está em processo de aumento da umidade a partir do solo seco, a tensão interfacial não é suficiente para ultrapassar o poro de raio $r_{2}$, deixando o mesmo sem água.

2.2 Espectrometria de Infravermelho

A espectrometria de infravermelho é um dos métodos utilizados para determinar a quantidade de hidrocarbonetos existentes em uma amostra. Este método é indicado para análises de amostras em grande quantidade, pois comparado com os outros métodos como a gravimetria e a cromatografia gasosa, é rápida e de baixo custo.

Segundo os estudos do TPH Criteria Working Group (apud Nascimento, 2003) A determinação do TPH, para os métodos que envolvem o infravermelho, é definida como sendo tudo o que o solvente extrai de uma amostra que possa ser detectada pelo infravermelho. A exatidão e precisão deste método são frequentemente baixas, especialmente para amostras não homogêneas de solo.

\subsubsection{T.P.H. (Total Petroleum Hidrocarbon)}

O parâmetro TPH (Total Petroleum Hydrocarbon) é frequentemente utilizado para a avaliação de uma área contaminada com derivados de petróleo. O TPH fornece a concentração de hidrocarbonetos totais presentes em uma amostra.

Existem diversos métodos para a determinação do TPH em uma amostra, como a cromatografia gasosa, infravermelho e a gravimetria. Os resultados de cada tipo de método apresentam diferentes concentrações de TPH, por isso, não é recomendado comparar concentrações de TPH resultantes de diferentes métodos analíticos, o que poderia causar erros na interpretação dos dados. Por isso, caso seja detectado por uma análise de TPH que exista contaminação por óleo, recomenda-se realizar outras análises para avaliar qualitativamente o risco do local (Nascimento et al., 2008). 


\subsubsection{Funcionamento do HATR-T2}

O Analisador InfraCal TOG/TPH, modelo HATR-T2 é um analisador de Totais de Óleos e Graxas, e de Hidrocarbonetos de Petróleo Totais (TPH). Através de solventes apropriados é possível extrair hidrocarbonetos das amostras que são quantificadas por um analisador.

Este aparelho não analisa amostras de hidrocarbonetos que sejam voláteis a temperaturas inferiores a de volatilização do solvente, pois para a análise, um volume determinado (que no caso deste trabalho foi definido como $60 \mu$ ) é disposto diretamente sobre a plataforma IR (infravermelho) para evaporar o solvente, deixando sobre a plataforma apenas a amostra de hidrocarbonetos. O hidrocarboneto extraído absorve a energia do infravermelho a um comprimento de onda específico, sendo a energia absorvida proporcional à concentração de óleos e graxas no solvente.

O analisador apresenta o resultado em absorbância relativa (AbS). Por isso há a necessidade de calibrá-lo antes de iniciar as análises das amostras. A calibração é feita preferencialmente com o mesmo óleo a ser analisado. A fabricante do equipamento recomenda a não utilizar concentrações acima de $4000 \mathrm{ppm}$, pois acima deste valor, a curva de calibração apresenta um comportamento distinto das concentrações abaixo de 4000ppm.

Nascimento et al. (2008) apresenta resultados com o analisador de óleos e graxas Infracal TOG/TPH, modelo $\mathrm{CVH}-50$, que é um aparelho semelhante ao utilizado no presente estudo. A diferença entre o equipamento utilizado e o citado, é a forma de como a amostra é analisada. No modelo $\mathrm{CVH}-50$, a amostra é colocada em uma cubeta de cristal, que é inserida no aparelho para a análise da quantidade de óleo presente na amostra, sendo que no HATR-T2 a amostra é diretamente disposta sobre a plataforma de cristal.

O modelo HATR-T2 pode ser utilizado apenas para a medição de TPH de óleos que possuam a temperatura de ebulição maior que o solvente utilizado, que no caso deste equipamento é o n-Hexano. Para o caso de óleos compostos (como a gasolina) que possuam componentes que sejam voláteis a temperatura ambiente, é indicado o uso do modelo CVH-50, utilizado por Nascimento et al. (2008). 


\subsection{HSSM (Hydrocarbon Spill Screening Model)}

O modelo HSSM (Hydrocarbon Spill Screening Model) versão 1.10 é um modelo desenvolvido para simular a pluma de dispersão de um hidrocarboneto que seja menos denso que a água (LNAPL) em solos. O modelo é baseado em aproximações das características do movimento desse tipo de poluente na zona vadosa, dispersão de LNAPL ao longo do nível da água, e transporte do constituinte miscível do LNAPL através do nível da água do aquífero até pontos receptores.

O LNAPL flui no sentido descendente pela zona vadosa pela ação da gravidade e da capilaridade dos poros do solo. O LNAPL pode ter sua rota alterada por heterogeneidade geológica à medida que caminha em direção ao aquífero. A água pluvial que infiltra no solo pode empurrar o LNAPL, acelerando a velocidade do LNAPL. Quando atinge o nível da água, o LNAPL (por ser imiscível e menos denso que a água) flutua na franja capilar. A variação do nível da água pode deixar uma zona contaminada com LNAPL preso nos poros do solo. O contato com a água do solo ou que se infiltra, faz com que alguns constituintes do LNAPL se dissolvam, resultando na contaminação do lençol freático. Esses constituintes podem se misturar em diferentes concentrações, dependendo de suas propriedades. Dependendo da volatilidade, os constituintes podem se misturar ao ar da zona vadosa.

O HSSM se baseia num conceito simplificado da dispersão do LNAPL: admitindo o fluxo unidimensional do LNAPL da superfície até o lençol freático, as propriedades do subsolo são consideradas uniformes, a composição do LNAPL é tida como uma parte líquida e outra são os constituintes químicos de interesse, no nível da água o LNAPL se dispersa radialmente (não são considerados os gradientes regionais para o fluxo do poluente). A geometria assumida pelo modelo HSSM está representada na Figura 2.8 abaixo. A dissolução dos constituintes químicos obedece ao equilíbrio local, mas é regido pelo fluxo do lençol freático e da água de recarga que chega ao nível da água. Os constituintes químicos são transportados por advecção e dispersão a múltiplos pontos receptores no aquífero uniforme. 
Superfície do Solo

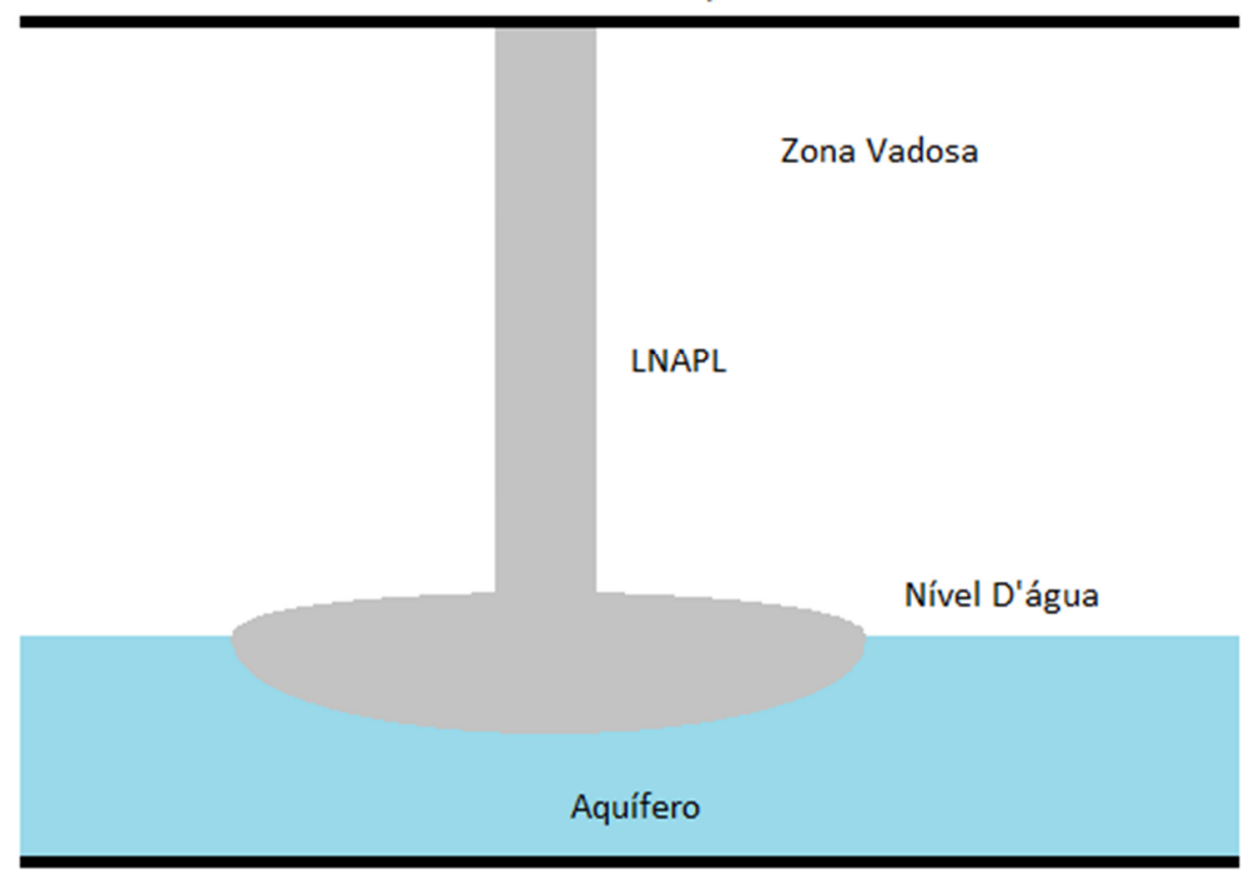

Figura 2.8 - Esquema da disposição de NAPL idealizado no programa HSSM (Modificado HSSM)

O modelo é composto por três módulos, todos estão em forma de solução semianalítica das equações que regem o movimento dos LNAPL's em solos, portanto esses módulos do HSSM não usam a discrição do domínio do fluxo nem soluções iterativas. Essas aproximações foram feitas para aumentar a rapidez da execução.

O modelo tem por objetivo identificar o problema do fluxo e transporte de LNAPL da superfície até o lençol freático. Assumindo que o interesse principal é a qualidade da água, uma ênfase do modelo é determinar da camada de NAPL e o fluxo do contaminante no aquífero. Essas quantidades definem as condições da fonte de contaminação do aquífero e precisa basear-se em fenômenos de fluxo multifásicos na zona vadosa. Os dois primeiros módulos do HSSM estão relacionados com o fluxo e o transporte do LNAPL na zona vadosa.

\subsubsection{Kinematic Oily Pollutant Transport (KOPT)}

Primeiro módulo do HSSM, onde simula o fluxo do NAPL na zona vadosa, até chegar ao aquífero. O derramamento pode ser simulado de três formas:

- fluxo conhecido e duração específica; 
- um volume conhecido é disposto a uma profundidade conhecida;

- o LNAPL é colocado com carga constante sobre o solo por um determinado período.

O efeito do fluxo de ar não é considerado, não inclui o transporte em fraturas ou macroporos e também não considera a dispersão.

O LNAPL é tratado como uma mistura de dois componentes, uma é o LNAPL considerado que não seja solúvel em água, e a outra parte são os constituintes químicos do LNAPL solúveis na água.

\subsubsection{OILENS}

A partir da chegada da frente da pluma de contaminação calculada pelo módulo anterior, é utilizado o OILENS, que simula a expansão radial da lente de óleo sobre o aquífero. É baseado em três aproximações:

- o LNAPL se espalha radialmente, o que implica em que a inclinação regional do lençol freático é pequena o suficiente para não interferir na locomoção da lente;

- a espessura é determinada apenas pela flutuabilidade;

- o formato da lente é dado pelos pressupostos de Dupuit, onde o fluxo é assumido como horizontal e o gradiente é aproximado pela mudança de carga pela distância horizontal. 


\section{Materiais e Métodos}

3.1 Ensaios de Laboratório

Para realização dos ensaios foi selecionada uma areia que tivesse granulometria média para fina, com baixa presença de mica. A areia é proveniente de Itapetininga-SP e foi utilizada para realização do ensaio do modelo físico, cujos detalhes serão apresentados e discutidos em outro item.

Foram realizados ensaios de caracterização da areia e de granulometria por peneiramento. O óleo utilizado em todos os experimentos é um óleo mineral de transformador recuperado, com características semelhantes ao óleo lubrificante Lubrax Industrial AV-10 da Companhia BR.

\subsubsection{Características do Óleo}

O óleo utilizado em todos os ensaios do presente trabalho foi o óleo lubrificante Lubrax Industrial AV-10. A natureza química é de destilado parafínico leve de petróleo, desaromatizado e desparafinado a solventes e hidratado. As características do óleo de acordo com a fabricante estão na Tabela 3.1 abaixo:

Tabela 3.1- Características do óleo AV-10.

\begin{tabular}{ll|l} 
Gravidade específica a $10 / 4^{\circ} \mathrm{C}$ & 0,8518 \\
\hline Viscosidade a $40^{\circ} \mathrm{C}$ & (cSt) & 10,0 \\
\hline Viscosidade a $100^{\circ} \mathrm{C}$ & (cSt) & 2,61 \\
\hline Fator de Dissipação a $90^{\circ} \mathrm{C}$ & (\%) & 0,04 \\
\hline Tensão Superficial, $25^{\circ} \mathrm{C}$ & (dyn/cm) & 48,3
\end{tabular}

cSt - centi Stokes

Os componentes solúveis em água deste óleo são insignificantes.

\subsubsection{Caracterização da Areia}

Foram feitos os ensaios de granulometria, densidade dos grãos, índice de vazios mínimo e máximo e permeabilidade com a areia utilizada no tanque experimental.

O ensaio de granulometria foi executado de acordo com a NBR 7181. Foi necessária apenas a execução do peneiramento grosso. 
A densidade dos grãos foi determinada de acordo com a NBR 6508.

Com o permeâmetro de carga constante foram executados ensaios de permeabilidade com a areia no estado mais fofo e mais compactada. Para o estado mais fofo, foi utilizado o método de extração rápida do tubo. E para o estado mais compactado, o material foi colocado em várias camadas e cada camada compactada com o auxílio de uma haste com base plana. No topo e na base do corpo de prova, foram colocados camadas de areia grossa, de modo a criar um filtro. Além disso, foi colocada uma tela para reter o material grosso.

A montagem é semelhante ao permeâmetro descrito na NBR 13292, sendo que no permeâmetro montado não foram utilizados o filtro de areia fina no reservatório de carga constante e o disco perfurado entre o corpo de prova e o material granular, e a água utilizada foi diretamente retirada da torneira.

Os resultados dos ensaios de peso específico dos grãos, índice de vazios e permeabilidade estão apresentados Tabela 3.2, e o gráfico da granulometria está representado na Figura 3.1. A areia é fina, com o CNU de 2,1, ou seja, mal graduada, praticamente sem a presença de mica, com os grãos levemente arredondados e a permeabilidade mínima e máxima sendo $4 \times 10^{-5}$ e $2 \times 10^{-4} \mathrm{~m} / \mathrm{s}$, respectivamente.

Tabela 3.2 - Características da areia de Itapetininga.

\begin{tabular}{lc|c}
\multicolumn{2}{l|}{ Peso Específico dos Grãos $(\gamma \mathrm{s})\left(\mathrm{kN} / \mathrm{m}^{3}\right)$} & 26,48 \\
\hline \multirow{2}{*}{ Índice de Vazios (e) } & Máximo & 0,71 \\
\cline { 2 - 3 } & Mínimo & 0,48 \\
\hline \multirow{2}{*}{ Permeabilidade (m/s) } & Máximo & $2 * 10^{-4}$ \\
\cline { 2 - 3 } & Mínimo & $4 * 10^{-5}$ \\
& &
\end{tabular}




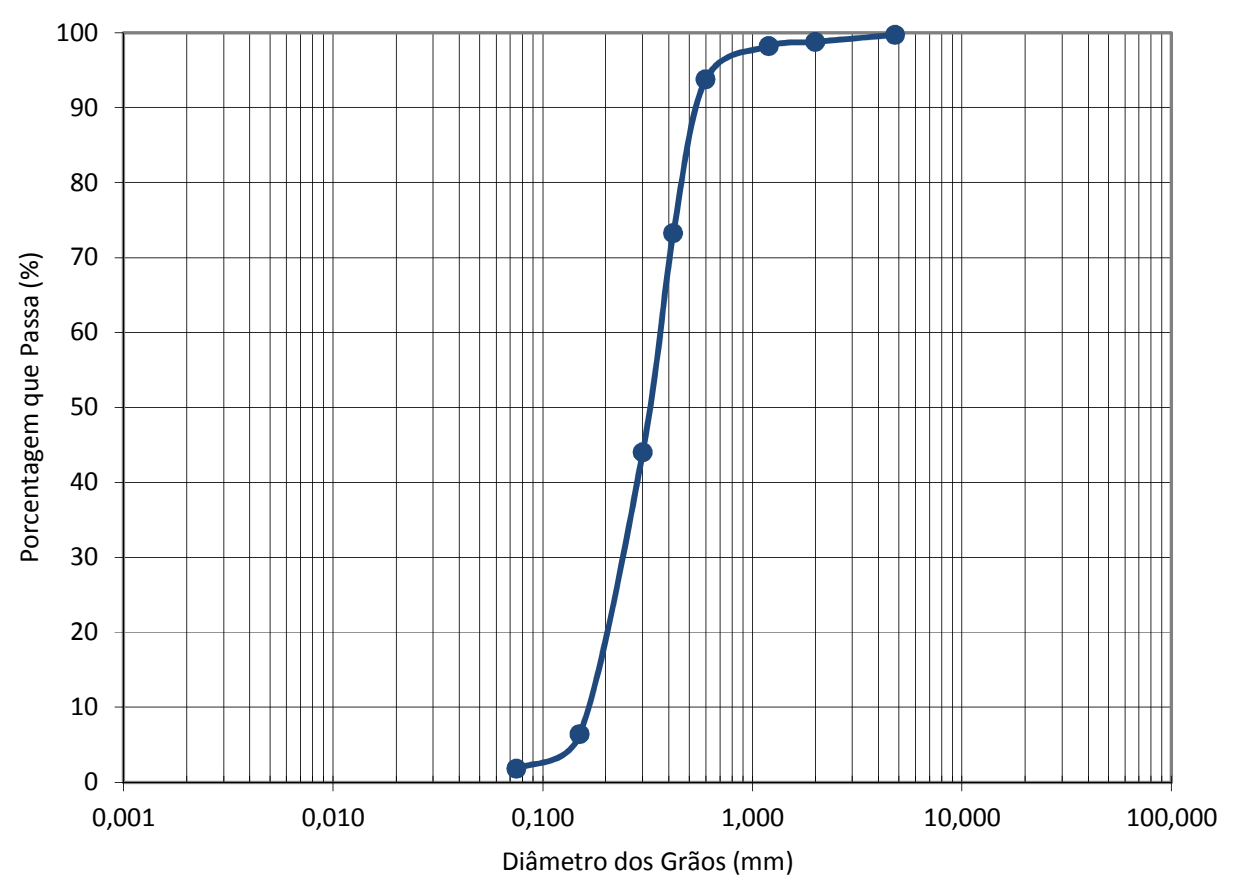

Figura 3.1 - Granulometria da areia de Itapetininga.

\subsubsection{Curva Característica}

A curva característica (ou de retenção) de um solo é importante porque estima alguns parâmetros relacionados à percolação de água no solo. Para a areia em questão foram utilizados dois métodos. O primeiro foi o da placa de sucção para a areia somente com água, e o segundo método foi o utilizado para medir a sucção total do solo, com determinadas concentrações de óleo.

\subsubsection{Primeiro método: Placa de Sucção para areia com água}

A placa de sucção impõe a amostra uma sucção por meio de vasos comunicantes, induzindo uma sucção matricial onde a água no corpo de prova apresenta-se com pressão relativa negativa, porém, acima do zero absoluto. Neste método a sucção é medida até $30 \mathrm{kPa}$, devido a limitações físicas do laboratório, pois a suç̧ão é imposta por meio de diferença de nível do corpo de prova com o reservatório de água. A Figura 3.2 apresenta as fotos do equipamento utilizado. 


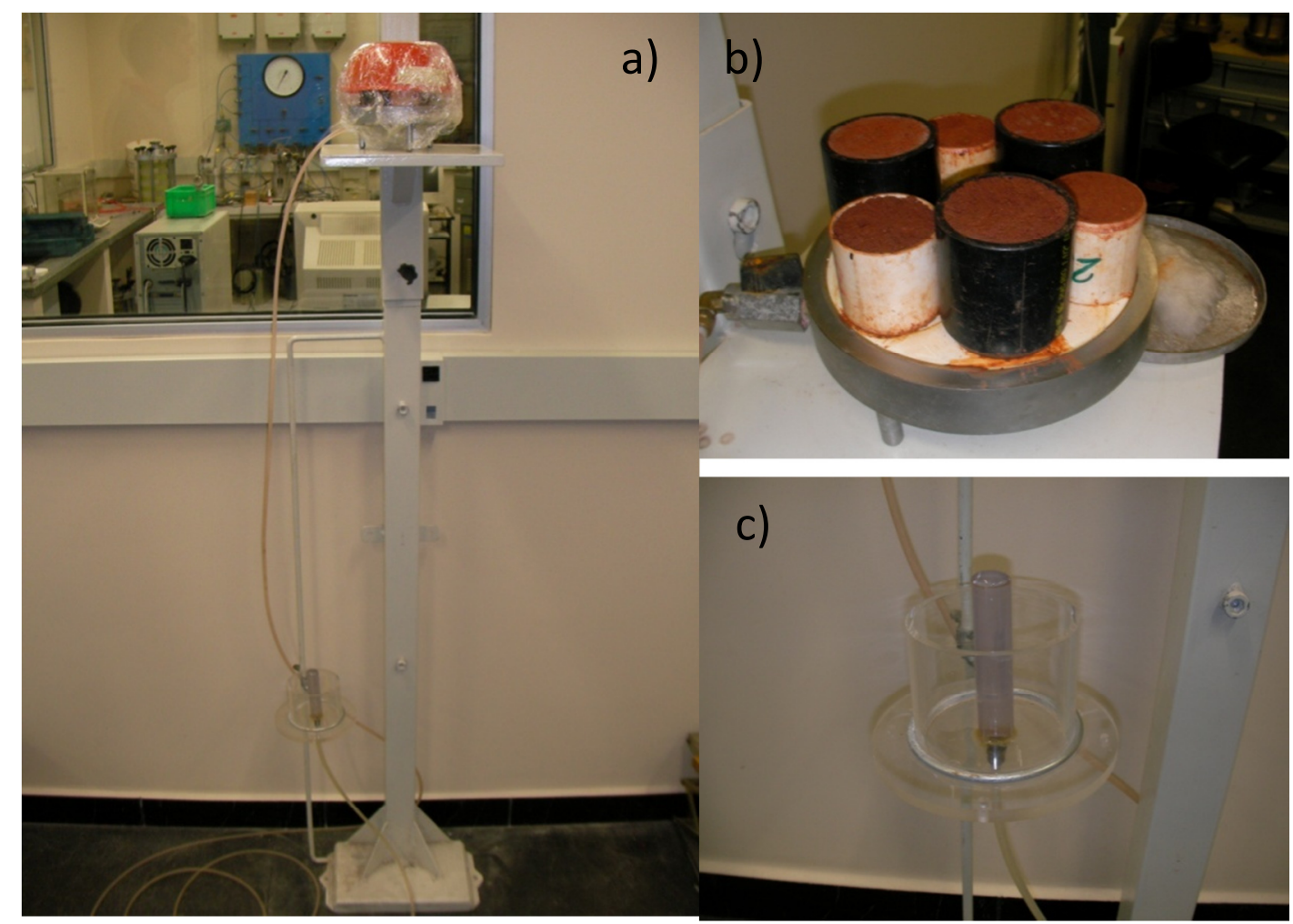

Figura 3.2 - Placa de sucção. a) vista geral do equipamento, b) placa de sucção com amostras, c) reservatório de água.

\section{Método do ensaio}

Inicialmente o corpo de prova é saturado, posicionando o topo do reservatório de água com o meio do corpo de prova. Para garantir a saturação, é recomendado deixar pelo menos durante 24 horas na mesma posição para o caso de uma areia. Por isso, a areia foi colocada em saturação pelo período de dois dias para garantir a saturação.

Com o corpo de prova saturado, posiciona-se o topo do reservatório de água 1 centímetro abaixo do centro do corpo de prova, que corresponde a uma sucção de 0,1 kPa. O tempo de estabilização da sucção é de 1 dia para areia. As etapas seguintes foram definidas com sucções de 0,5, 1, 2, 5, 10 e 20kPa. 


\subsubsection{Segundo método: Papel Filtro para amostra com óleo}

Para estudar a diferença de comportamento de um solo somente com água com outro contaminado por óleo, foram executados ensaios de obtenção da curva de retenção pelo método do papel filtro para medir a suç̧ão total.

\section{Método do ensaio}

O método foi baseado no estudo de Vivian (2009), onde estuda a determinação da curva característica de um solo contaminado por óleo diesel. O método consiste em posicionar o papel filtro a uma distância constante do corpo de prova contaminado, e armazenar o conjunto por um período de tempo suficiente para a equalização da sucção do corpo de prova e do papel filtro. A Figura 3.3 apresenta o esquema do conjunto.

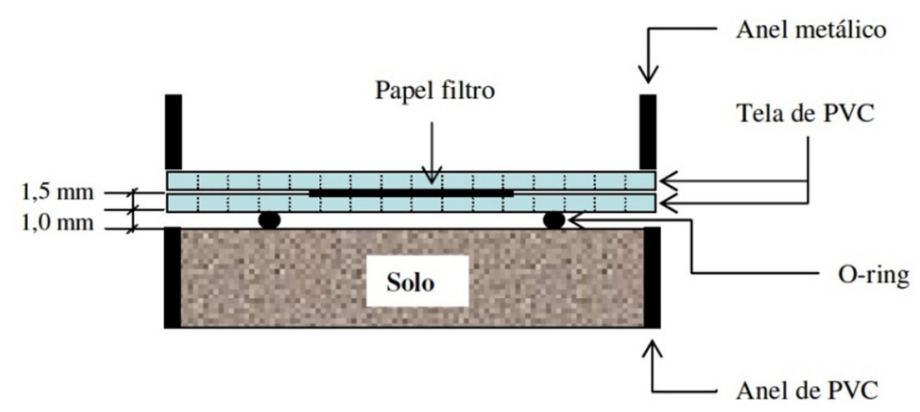

Figura 3.3 - Esquema da disposição do papel filtro (Vivian, 2009).

O ensaio foi executado com modificações, substituindo o anel de PVC por um recipiente de vidro ou de cerâmica. No total foram feitos 42 corpos de prova, variando a porcentagem de óleo entre $0 \%$ até $15 \%$. Sendo os corpos de prova com $13 \%$ de água condicionada em recipientes de vidro e os demais em recipiente cerâmico. $\mathrm{O}$ ensaio foi iniciado em recipientes de vidro para poder observar se devido à compactação a água acumulava no fundo. Depois de observado que isto não ocorria, foram utilizados recipientes de cerâmica pelo custo reduzido em relação ao copo de vidro. A porcentagem de água e de óleo foi calculada a partir do peso de solo seco. A Tabela 3.3 apresenta as porcentagens de óleo e água de cada corpo de prova. E a Tabela 3.4 apresenta o peso do solo misturado com água e/ou óleo compactado em cada corpo de prova. 
Tabela 3.3 - Nomenclatura dos corpos de prova.

\begin{tabular}{|c|c|c|c|c|c|c|}
\hline \multirow{3}{*}{$\begin{array}{c}\% \\
\text { de } \\
\text { Óleo }\end{array}$} & \multicolumn{6}{|c|}{ Nomenclatura do corpo de prova } \\
\hline & \multicolumn{4}{|c|}{ Cerâmico } & \multicolumn{2}{|c|}{ Vidro } \\
\hline & 3\% de água & $6 \%$ de água & $9 \%$ de água & $11 \%$ de água & 13\% de água & Outros \\
\hline $2 \%$ & $\begin{array}{l}\text { CP01 (A3O2) e } \\
\text { CP02 (A3O2) }\end{array}$ & $\begin{array}{l}\text { CP09 (A6O2) e } \\
\text { CP10 (A6O2) }\end{array}$ & $\begin{array}{l}\text { CP17 (A9O2) e } \\
\text { CP18 (A9O2) }\end{array}$ & $\begin{array}{l}\text { CP25 (A11O2) e } \\
\text { CP26 (A1102) }\end{array}$ & $\begin{array}{l}\text { CP33 (A13O2) e } \\
\text { CP34 (A1302) }\end{array}$ & \\
\hline $5 \%$ & $\begin{array}{l}\text { CP03 (A3O5) e } \\
\text { CP04 (A3O5) }\end{array}$ & $\begin{array}{l}\text { CP11 (A605) e } \\
\text { CP12 (A6O5) }\end{array}$ & $\begin{array}{l}\text { CP19 (A905) e } \\
\text { CP20 (A905) }\end{array}$ & $\begin{array}{l}\text { CP27 (A1105) e } \\
\text { CP28 (A1105) }\end{array}$ & $\begin{array}{l}\text { CP35 (A1305) e } \\
\text { CP36 (A1305) }\end{array}$ & \\
\hline $10 \%$ & $\begin{array}{l}\text { CP05 (A3O10) } \\
\text { e } \\
\text { CP06 (A3010) }\end{array}$ & $\begin{array}{l}\text { CP13 (A6010) } \\
\text { e } \\
\text { CP14 (A6010) }\end{array}$ & $\begin{array}{l}\text { CP21 (A9010) } \\
\text { e } \\
\text { CP22 (A9010) }\end{array}$ & $\begin{array}{l}\text { CP29 (A11010) } \\
\text { e } \\
\text { CP30 (A11010) }\end{array}$ & $\begin{array}{l}\text { CP37 (A13010) } \\
\text { e } \\
\text { CP38 (A13010) }\end{array}$ & \\
\hline $15 \%$ & $\begin{array}{l}\text { CP07 (A3O15) } \\
\text { e } \\
\text { CP08 (A3015) }\end{array}$ & $\begin{array}{l}\text { CP15 (A6015) } \\
\text { e } \\
\text { CP16 (A6015) }\end{array}$ & $\begin{array}{l}\text { CP23 (A9O15) } \\
\text { e } \\
\text { CP24 (A9015) }\end{array}$ & $\begin{array}{l}\text { CP31 (A11015) } \\
\text { e } \\
\text { CP32 (A11015) }\end{array}$ & $\begin{array}{l}\text { CP39 (A13015) } \\
\text { e } \\
\text { CP40 (A13015) }\end{array}$ & \\
\hline $\begin{array}{l}\text { Só } \\
\text { óleo }\end{array}$ & & & & & & $\begin{array}{l}\text { CP41 } \\
\text { (O20) }\end{array}$ \\
\hline $\begin{array}{l}\text { Só } \\
\text { água }\end{array}$ & & & & & & $\begin{array}{l}\text { CP42 } \\
\text { (A27) }\end{array}$ \\
\hline
\end{tabular}

Tabela 3.4 - Peso de solo com água e/ou óleo de cada copo.

\begin{tabular}{c|c|c|c|c|c|c} 
& \multicolumn{5}{|c}{ Peso do solo com água e/ou óleo (g) } \\
$\begin{array}{c}\text { \% de } \\
\text { Óleo }\end{array}$ & $\begin{array}{c}\text { Copo cerâmico } \\
\text { 3\% de } \\
\text { água }\end{array}$ & $\begin{array}{c}6 \% \text { de } \\
\text { água }\end{array}$ & $\begin{array}{c}9 \% \text { de } \\
\text { água }\end{array}$ & $\begin{array}{c}11 \% \text { de } \\
\text { água }\end{array}$ & $\begin{array}{c}\text { Copo de vidro } \\
\text { água }\end{array}$ & Outros \\
\hline $2 \%$ & 211,77 & 217,92 & 224,07 & 228,17 & 231,75 & \\
\hline $5 \%$ & 212,69 & 218,84 & 224,99 & 229,09 & 232,68 & \\
\hline $10 \%$ & 214,23 & 220,38 & 226,53 & 230,63 & 243,21 & \\
\hline $15 \%$ & 215,76 & 221,91 & 228,06 & 232,16 & 235,75 & \\
\hline Só óleo & & & & & & 225,00 \\
\hline Só água & & & & & & 232,00
\end{tabular}

Para padronizar o procedimento de moldagem dos corpos de prova, todos foram moldados para ter volume de $125 \mathrm{ml}$. O índice de vazios utilizado como referência para a moldagem dos corpos de prova foi de 0,61 , pois foi índice de vazios médio do solo compactado no tanque experimental. Para isso o peso de solo seco a ser compactado no copo é de $205 \mathrm{~g}$, sendo a densidade do solo seco $\left(\rho_{\mathrm{d}}\right)$ igual a $16,4 \mathrm{kN} / \mathrm{m}^{3}$. 
Todos os corpos de prova foram moldados duplicados, exceto os corpos de prova CP41 (O20) e CP 42 (A27), com óleo e água, respectivamente.

A sequência de moldagem dos corpos de prova está mostrada na Figura 3.4, e descrita a seguir:

- Inicialmente, foi medido o volume de $125 \mathrm{ml}$ de água, colocado no recipiente, e marcado o nível, para utilizar como referência para o volume do corpo de prova (Figura 3.4-a);

- Em seguida foi preparado o solo com a umidade e a porcentagem de óleo controlada, de acordo com a Tabela 3.3;

- Deste solo preparado, foi compactado o peso de acordo com a Tabela 3.4, para cada recipiente (Figura 3.4-b);

- Sobre o solo compactado foi colocado um o-ring e uma tela de nylon (Figura 3.4-c, d);

- Em cima da tela de nylon, foi colocada uma folha de papel filtro da marca Whatman, modelo $n^{\circ} 42$ (Figura 3.4-e);

- Mais uma tela de nylon foi colocada para evitar o contato do peso PVC com o papel filtro (Figura 3.4-f, g);

- Finalizando, o copo inteiro foi envolvido com o filme de PVC, e armazenado em uma caixa de Isopor (Figura 3.4-h).

Para garantir a equalização da sucção do papel filtro com a sucção do corpo de prova, é necessário armazenar os corpos de prova durante o período de duas a quatro semanas, dependendo da sucção. 

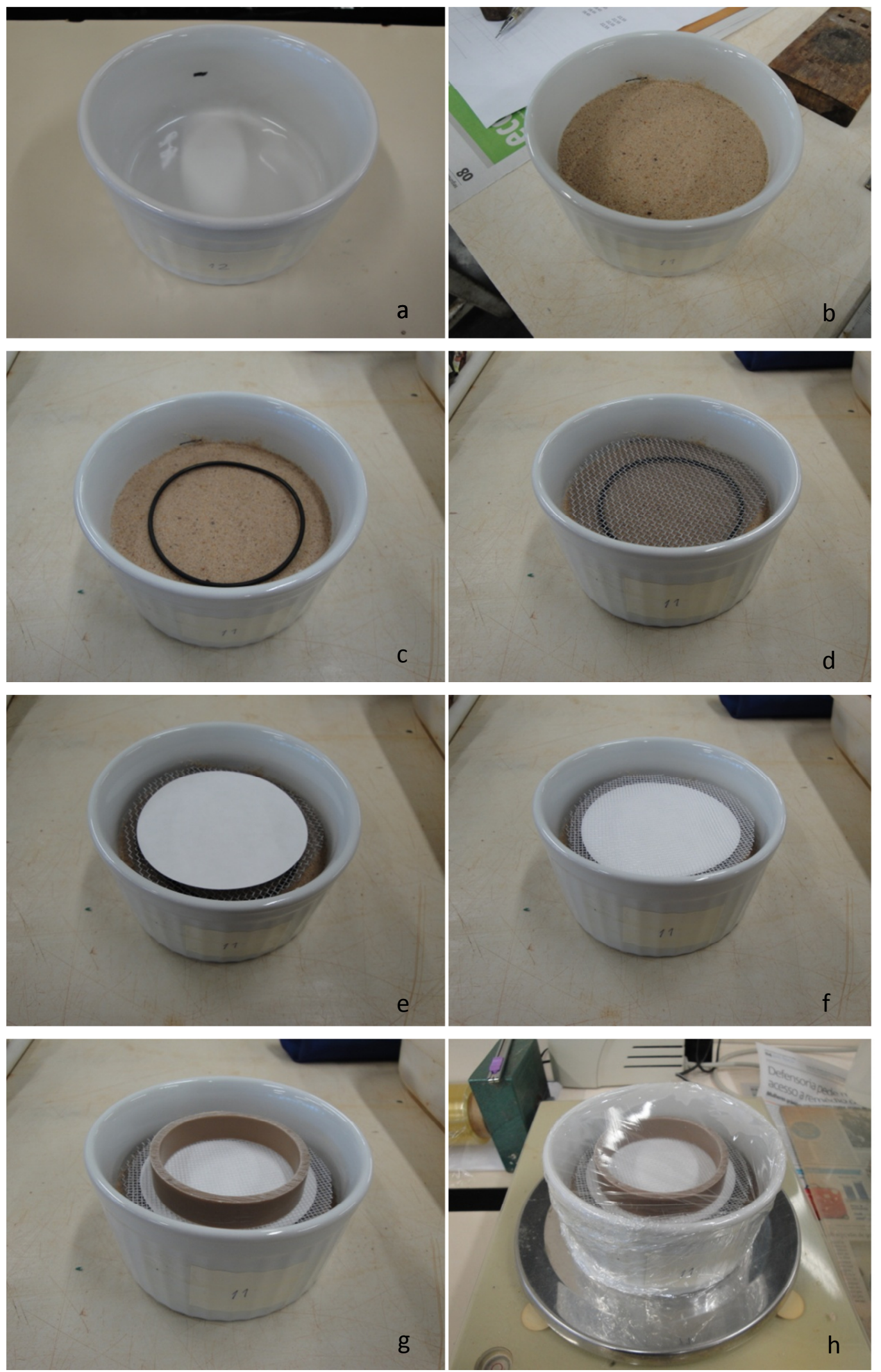

Figura 3.4 - Processo de moldagem do corpo de prova. 
3.2 Ensaio com o Modelo Físico

Um modelo físico foi construído para simular, e em três dimensões, o derramamento de óleo sobre o solo. A principal característica de um modelo físico é ter as condições de ensaio bem controladas, como início e término do derramamento, densidade do solo, gradiente do aquífero, condições climáticas, o que seria difícil de obter em um caso real.

No Anexo I está o procedimento de construção do tanque experimental.

\subsubsection{Ensaio de Derramamento de Óleo}

Foram executados três ensaios de derramamento de óleo no tanque experimental. O primeiro foi executado com a areia seca à umidade higroscópica, o segundo com um determinado nível d’água, e o terceiro com a areia úmida, mas sem nível de água.

Os objetivos destes ensaios são coletar dados sobre o comportamento do óleo derramado no solo, como se comporta a velocidade de infiltração do óleo no solo, formato da pluma de contaminação formada pelo óleo e a concentração de óleo ao longo da pluma.

O primeiro ensaio teve como objetivo construir um local com menos variáveis (sem água) para possibilitar a visualização da pluma de óleo. O segundo possui nível de água para poder observar do comportamento da pluma de contaminação quando atinge o nível de água, e o terceiro foi ajustado para ter um ambiente mais parecido com o real, com o solo úmido, mas sem nível de água perto da superfície.

\subsubsection{Primeiro ensaio: Tanque experimental com areia seca}

Para o primeiro ensaio, foi necessário que a areia estivesse seca, então foi iniciado o procedimento para a secagem. A areia foi seca ao sol espalhada sobre uma lona, e depois de seco, ensacado em sacos de ráfia para ser pesado antes de ser compactado no tanque, possibilitando o controle da densidade do solo dentro do tanque. $O$ índice de vazios do solo foi de e $=0,61$, com a densidade do solo seco de $\rho_{d}=16,4 \mathrm{kN} / \mathrm{m}^{3}$.

A compactação da areia foi executada em camadas de $20 \mathrm{~cm}$ com o auxílio de um sarrafo com uma placa de $20 \mathrm{~cm}$ por $20 \mathrm{~cm}$ na base. 
Com o tanque preenchido com a areia compactada, foi posicionado um tubo guia para derramar o óleo (Fig. 3.5). Este tubo tem $27 \mathrm{~cm}$ de diâmetro e $27 \mathrm{~cm}$ de profundidade, possibilitando o derramamento de 15 litros de óleo de uma só vez. A posição do tubo foi definida de maneira a não ser necessário o reposicionamento no o segundo ensaio, onde existirá um gradiente hidráulico na direção da direita para a esquerda segundo o posicionamento da Figura 3.5.

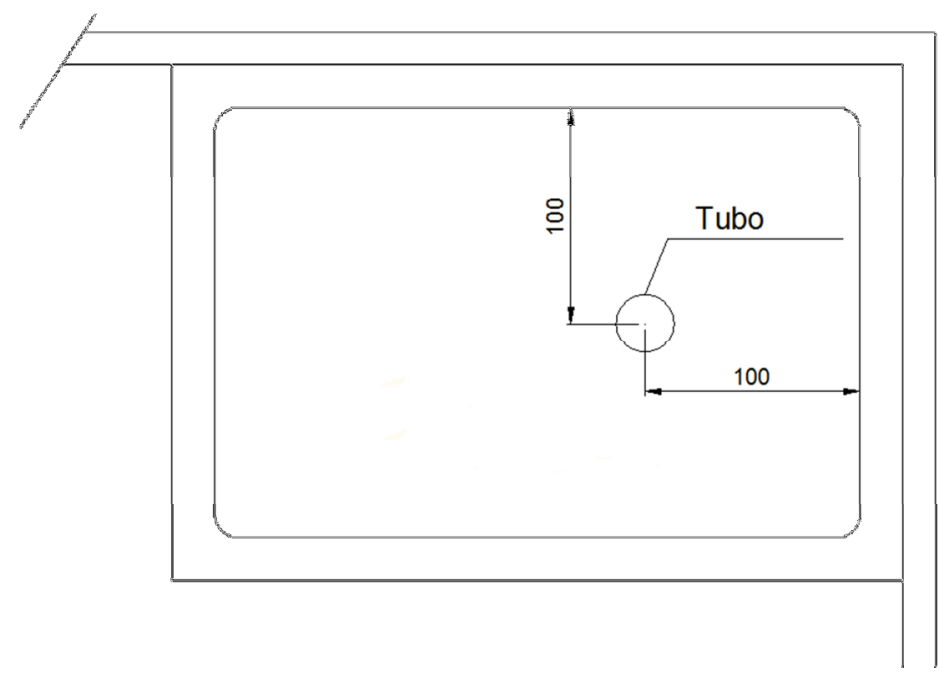

Figura 3.5 - Posição do tubo guia.

\subsubsection{Segundo ensaio: Esquema com aquífero perto da superfície}

No segundo ensaio não foi necessário secar a areia. Por isso, a compactação foi executada com o controle de umidade do solo. A cada camada de solo compactado foi retirado duas amostras de solo para determinar a umidade, e a partir disto foi estimada a umidade na compactação.

Com o tanque preenchido com a areia compactada, foi iniciada a saturação do solo por água. Utilizando as entradas de água posicionadas na parte inferior do tanque, iniciou-se a saturação no sentido de baixo para cima, para evitar o máximo possível que bolhas de ar ficassem presas no interior do solo.

Para auxiliar o monitoramento da saturação do solo do tanque, foram utilizado tensímetros, que de acordo com a sucção registrada em cada um, era possível saber o nível d'água no momento. A Figura 3.6 apresenta os tensímetros inseridos no solo nas profundidades de 60, 80, 100 e $120 \mathrm{~cm}$ a partir da superfície. 


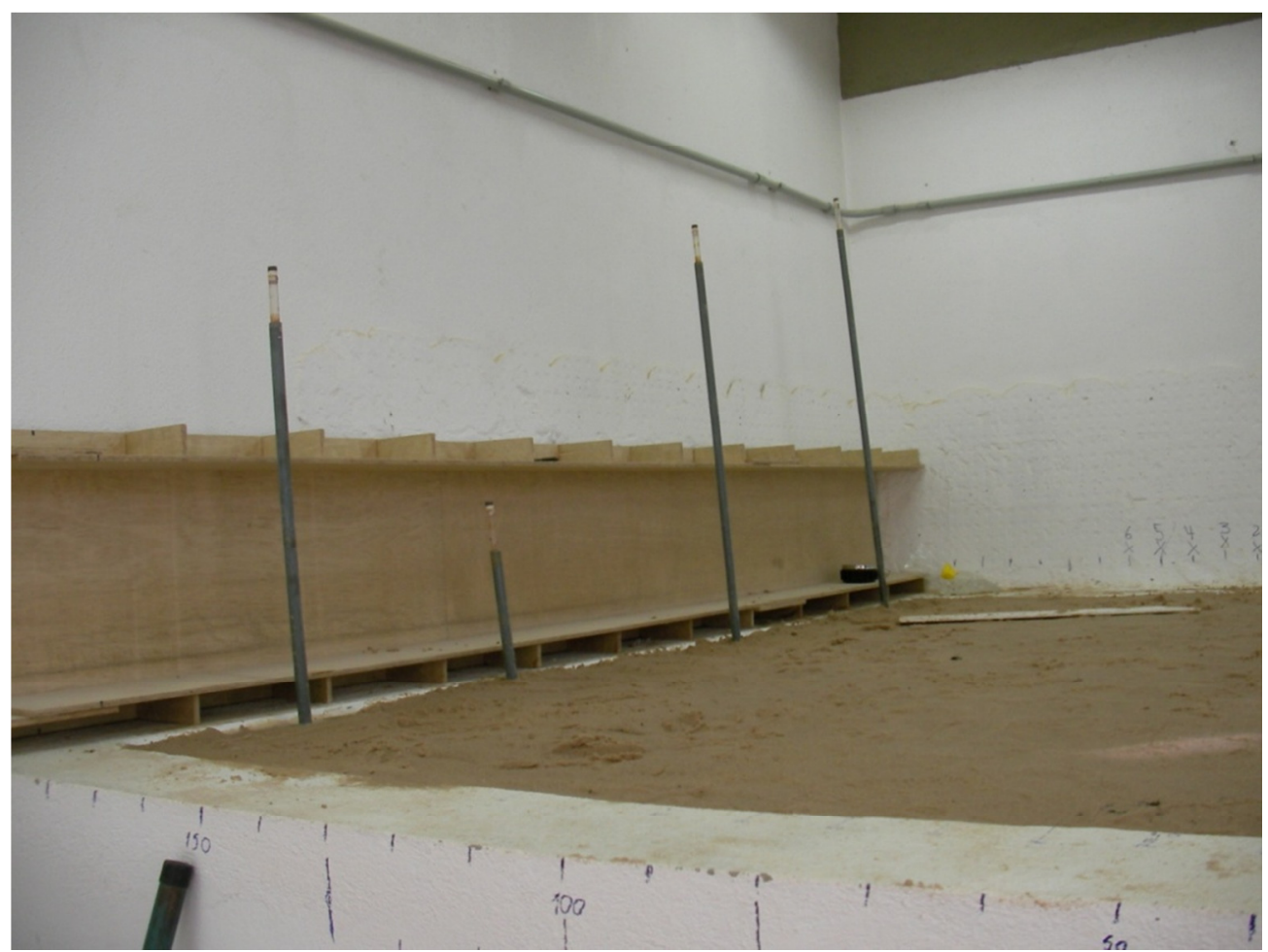

Figura 3.6 - Tensímetros inseridos no solo.

Uma vez atingido o objetivo de saturar o solo do tanque, foi iniciada a simulação da situação de um terreno com um nível d'água a cerca de $100 \mathrm{~cm}$ de profundidade. Para isso foi utilizado o sistema para controlar o nível d'água, posicionando a primeira caixa com o nível d'água a $90 \mathrm{~cm}$ a partir da superfície do tanque, e o segundo tanque a 100 cm da superfície do tanque. A Figura 3.7 apresenta este esquema.

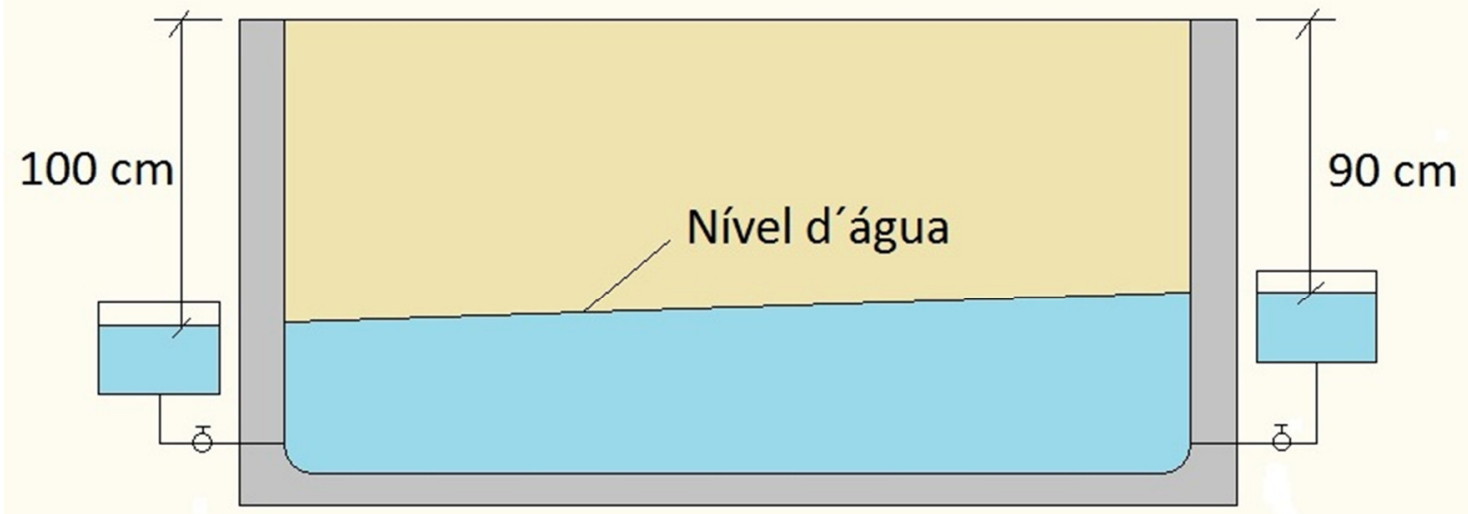

Figura 3.7 - Sistema de controle de nível d'água. 
Com este esquema, foi gerado um gradiente no nível d'água de $10 \mathrm{~cm}$ em 3 metros. Este gradiente tem como objetivo controlar a direção da pluma de contaminação de óleo. Esperou-se dois dias com este fluxo para garantir a estabilidade do sistema.

\subsubsection{Terceiro ensaio: Esquema com aquífero longe da superfície}

Neste ensaio também não foi necessário secar o solo antes da compactação. A sequência de compactação do solo foi semelhante ao segundo ensaio, até a parte de saturação do solo. Depois de concluída a saturação do solo, foi liberada toda água livre existente no meio pela abertura das válvulas existentes na base do tanque experimental.

\subsubsection{Análise das amostras coletadas}

A análise foi realizada no Laboratório de Mecânica dos Solos da USP, com o analisador de óleos e graxas da empresa Wilks Enterprise modelo HATR-T2.

\subsubsection{Calibração do equipamento}

Antes de analisar as amostras coletadas no tanque experimental, foi necessário executar a calibração do analisador InfraCal TOG/TPH, modelo HATR-T2 (Fig. 3.8). Para isso, foi necessário preparar padrões de concentração conhecida. O solvente utilizado para as análises foi o n-Hexano HPLC da Carlos Erba. O ponto de ebulição é de $69 \mathrm{C}^{\circ}$, e como o óleo utilizado tem o fator de dissipação de $0,04 \%$ a $90 C^{\circ}$, não há preocupação de o óleo evaporar durante a análise.

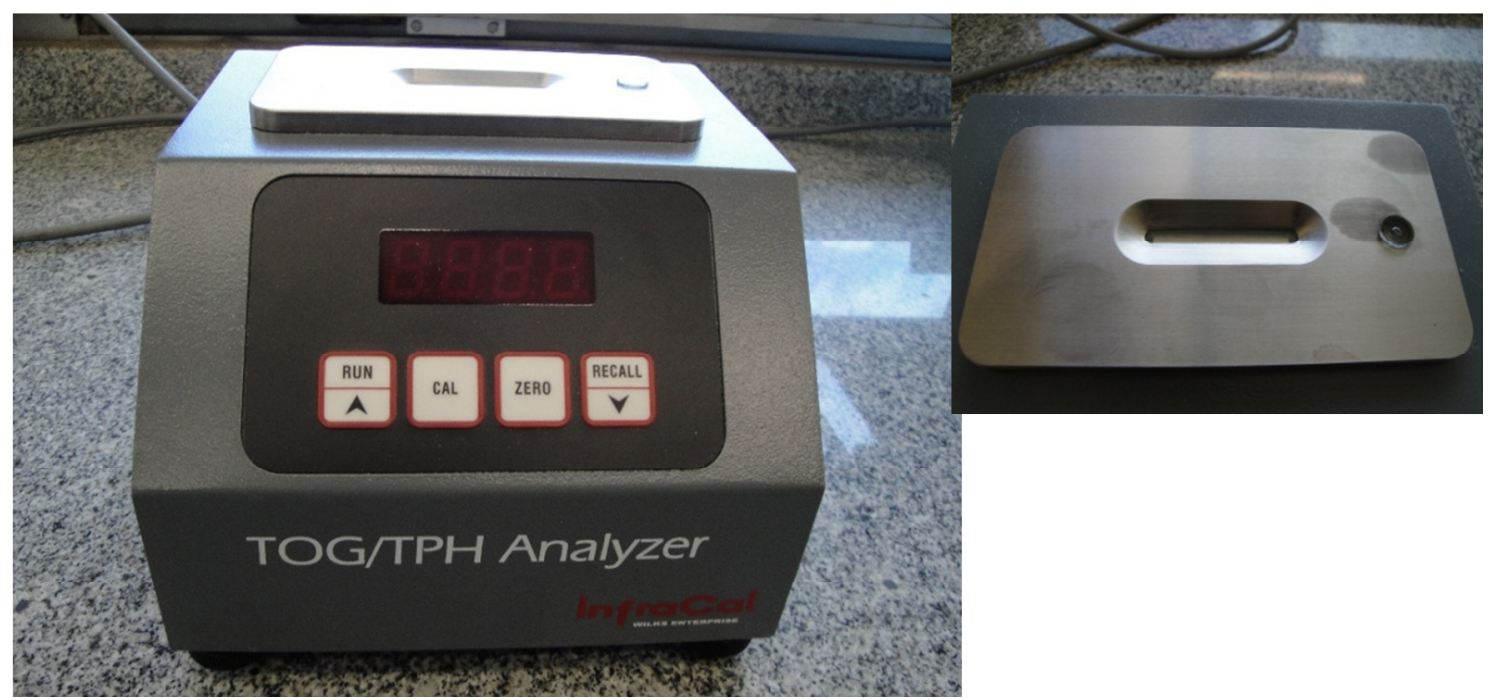

Figura 3.8 - Analisador InfraCal TOG/TPH, com o detalhe da plataforma de cristal a direita. 
Para utilizar o equipamento, precisa-se primeiramente fazer sua calibração, que por sua vez, se dá seguindo as seguintes etapas:

\section{a) Zerar o equipamento}

- Limpar a plataforma de cristal com solvente, colocando uma pequena quantidade de solvente, e removendo-a em seguida com um papel macio;

- Pressionar a tecla ZERO.

\section{b) Leitura de absorbâncias dos padrões de calibração}

- Pressionar e segurar a tecla CAL até que apareça a palavra CAL no visor;

- Dispor sobre a plataforma de cristal uma quantidade definida do padrão de calibração de concentração mais baixa. Pressionar a tecla RUN. Depois de 1 minuto o valor de absorbância será mostrado. O tempo de evaporação do solvente foi ajustado de acordo com as condições do ambiente, de maneira que 1 minuto era suficiente para isso;

- Lavar a plataforma com solvente;

- Dispor sobre a plataforma o segundo padrão de calibração de concentração mais baixa e pressionar a tecla RUN.

- Novamente anotar o valor de absorbância;

- Repetir os mesmos procedimentos para todos os padrões.

\section{c) Edição dos valores de absorbância e suas respectivas concentrações}

- Apertar e soltar a tecla CAL até que apareça CAL no visor;

- Apertar e soltar a tecla RECALL até que apareça EDIT;

- Apertar e soltar a tecla CAL, e o visor mostrará " $n=00$ ". Se qualquer número diferente de 00 aparecer no visor, use o botão RECALL (este botão pode ser usado como uma seta) para atingir 00.

- Apertar a tecla CAL e o visor mostrará a palavra EDIT;

- Apertar e solte a tecla CAL e agora o visor mostrará n=00; 
- Utilizando a tecla RUN para subir e RECASLL para descer, entre com o número de pontos de calibração / padrões a serem usados;

- Pressionar e solte a tecla CAL. O visor irá mostrar rapidamente "A01=". Usando a tecla RUN para aumentar e RECALL para diminuir entre com o valor de absorbância correspondente a primeira concentração (mais baixa)

- Apertar e solte a tecla CAL e o visor mostrar rapidamente "C01=". Utilizando as mesmas teclas para aumentar e diminuir, entre com os valores de concentração em $\mathrm{mg} / \mathrm{L}$ do padrão de calibração correspondente;

- Apertar e solte a tecla CAL e o visor mostrará rapidamente A02. Repita os procedimentos citados;

- Quando acabar a última amostra. Apertar e solte a tecla CAL. O visor mostrará IDLE. O analisador está calibrado e pronto para receber amostras.

De acordo com a metodologia acima descrita, foi executada a calibração do equipamento HATR-T2. Foram preparados padrões com concentrações que variavam de 100 a $20000 \mathrm{mg} / \mathrm{l}$. O resultado está na Figura 3.9 abaixo.

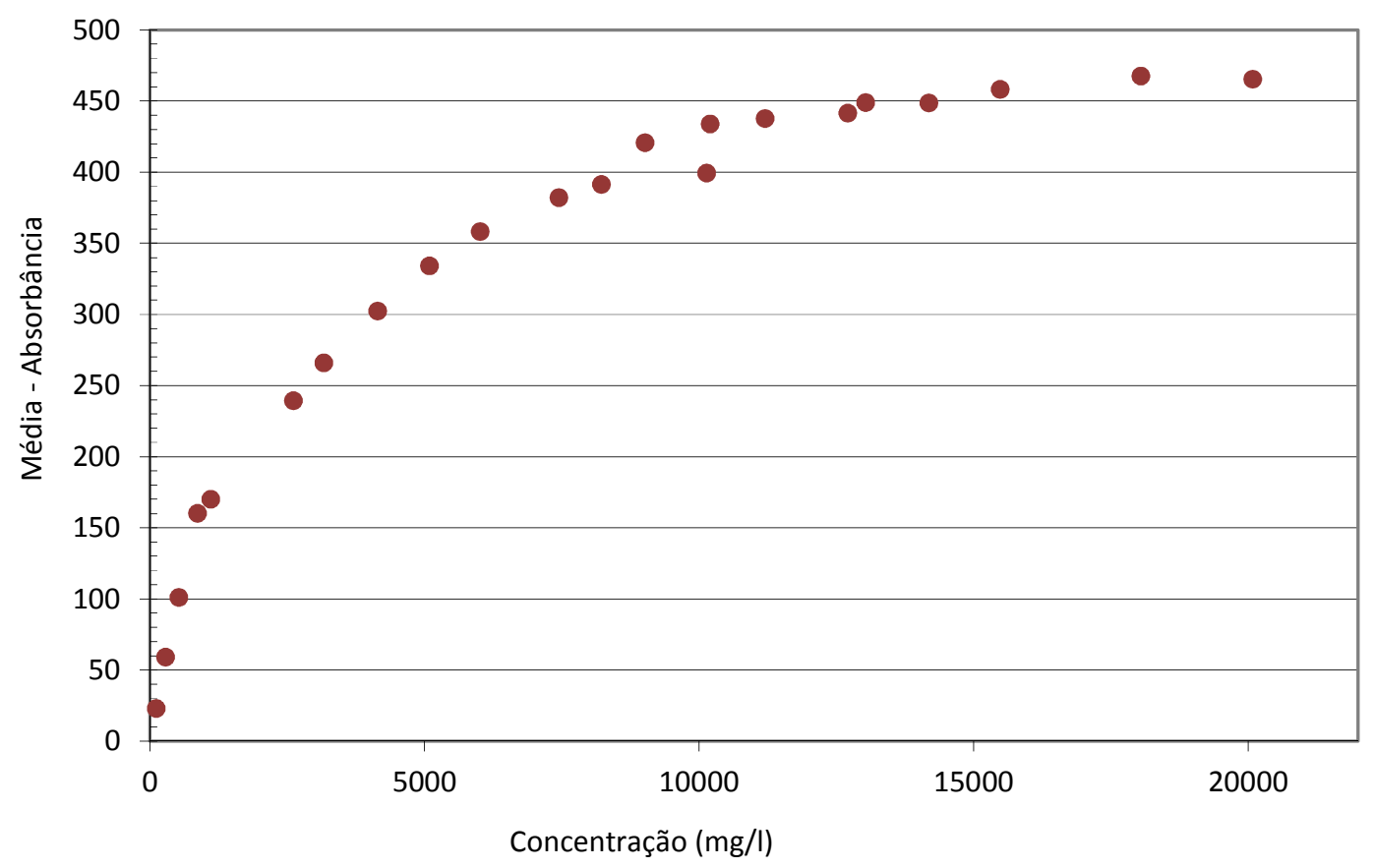

Figura 3.9 - Dados obtidos para a calibração do equipamento HATR-T2. 
Observa-se que quanto maior a concentração de óleo presente na amostra, menor fica a diferença com a amostra anterior, o que dificulta muito a análise da quantidade de óleo nas amostras. Para evitar a faixa de concentração que não há precisão, foi utilizado os pontos obtidos na faixa de 0 a $6000 \mathrm{mg} / \mathrm{l}$. A Figura 3.10 abaixo mostra os pontos destacados.

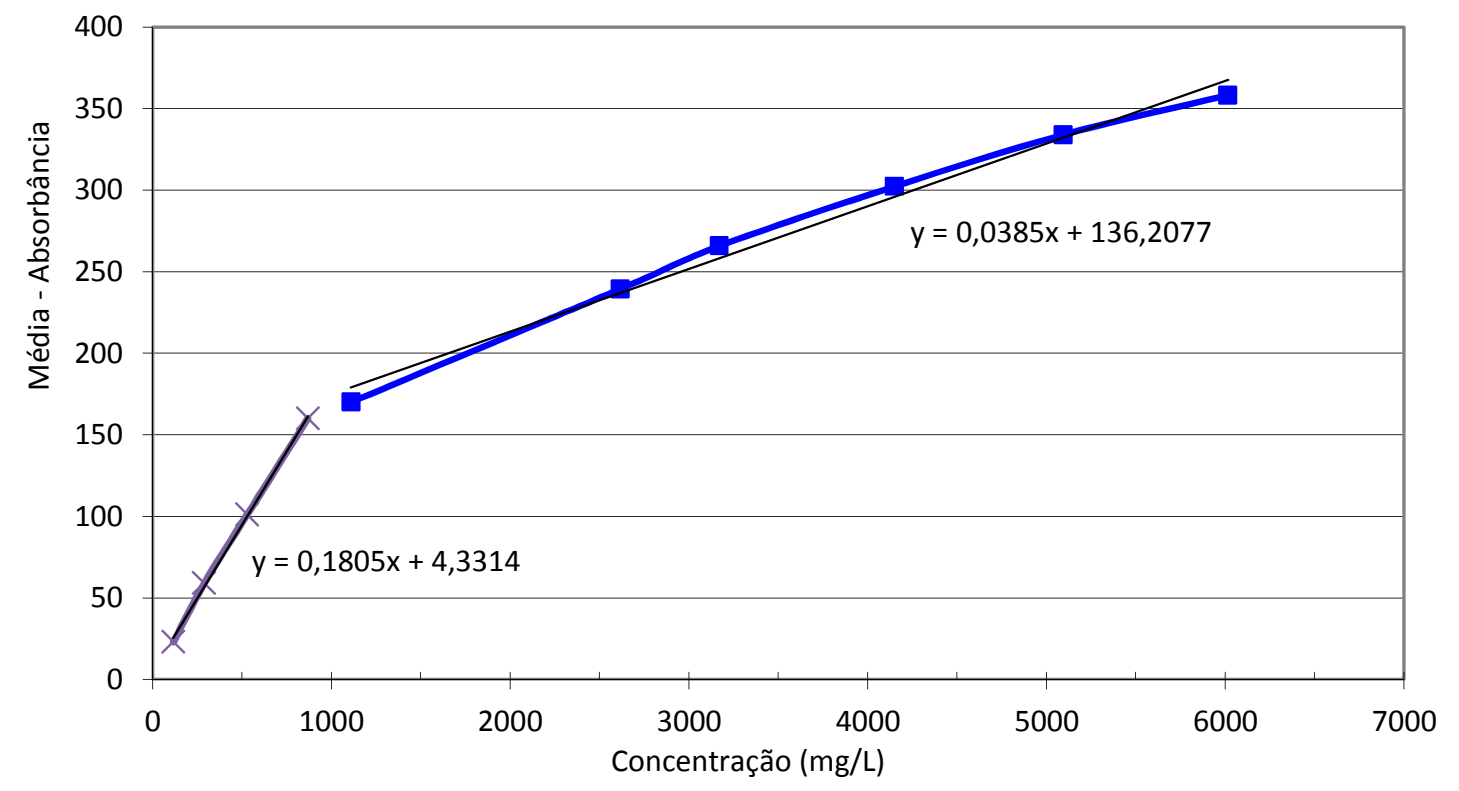

Figura 3.10 - Pontos com suas respectivas linhas de tendência

Pode ser observado que após a concentração de 4000 mg/l, o gráfico apresenta uma leve curva, como é descrito no manual do equipamento. 0 ideal seria conter a concentração das amostras na faixa de 1000 a 4000 mg/l, onde não há esse efeito, mas como as amostras coletadas apresentaram variações acima destas concentrações, foi utilizado a faixa de 1000 a 6000 mg/l de concentração como faixa de referência.

Para concentrações abaixo de $1000 \mathrm{mg} / \mathrm{l}$, está apresentada outra calibração. Isso se deve ao fato de o equipamento apresentar comportamento diferente para valores entre 0 e $1000 \mathrm{mg} / \mathrm{l}$. 
As equações são as seguintes:

Para 0 a 1000 mg/l:

$$
C=\frac{A b S-4,33}{0,1805}
$$

Para 1000 a $6000 \mathrm{mg} / \mathrm{l}:$

$$
C=\frac{A b S-136,21}{0,0385}
$$

Onde C é a concentração, AbS é a absorbância média.

Com a calibração devidamente executada, foram analisadas as amostras coletadas no tanque experimental. O procedimento da análise foi baseado no método utilizado por Nascimento, 2003, com algumas adaptações, pois o aparelho utilizado em seu trabalho é diferente.

A sequência da análise foi a seguinte:

a) Homogeneizar a amostra manualmente por um minuto;

b) Quartear a amostra até ficar com a quantidade de aproximadamente 20g;

c) Com o auxílio de um funil, colocar 5 gramas do solo contaminado em um balão volumétrico de $50 \mathrm{ml}$;

d) Utilizando uma proveta, colocar 25 a $30 \mathrm{ml}$ de solvente no balão volumétrico;

e) Tampar o balão e extrair o óleo com o auxílio de um agitador orbital a $200 \mathrm{rpm}$ por duas horas;

f) Completar o balão volumétrico com o solvente;

g) Com uma pipeta, transferir a quantidade de $60 \mu \mathrm{l}$ para a plataforma de cristal previamente limpa com solvente e efetuar a leitura.

\subsubsection{Análise das amostras coletadas}

Foram selecionadas amostras de solo contaminado de maneira a conter principalmente amostras com numeração entre 1 a 16, e algumas amostras da região fora da região perto do derramamento. 
A concentração em porcentagem é calculada dividindo o peso de óleo presente na amostra pelo peso da amostra menos o peso do óleo:

$$
o(\%)=\frac{P_{o}}{\left(P_{A}-P_{o}\right)}
$$

Onde:

$P_{0}=$ Peso do óleo na amostra;

$\mathrm{P}_{\mathrm{A}}=$ Peso da amostra;

$o(\%)=$ Concentração de óleo.

\subsection{Simulação numérica no HSSM}

O programa HSSM foi utilizado para simular o comportamento do NAPL no solo nas condições de cada ensaio executado no tanque experimental. A seguir estão os parâmetros necessários para a utilização do programa HSSM. Para facilitar a simulação, foi considerado que a temperatura ambiente em todos os casos é de $20^{\circ} \mathrm{C}$.

\subsubsection{Propriedades Hidrológicas}

\section{Hydrologic Parameters}

\section{HYDROLOGIC PROPERTIES}

Water dynamic viscosity [cp] .... 1

Water density $\left[\mathrm{g} / \mathrm{cm}^{3}\right] \ldots \ldots \ldots . . .1$

Water surf. tension [dyne/cm] ... 65

Maximum krw during infiltration . . . 7

Recharge
Average recharge rate $(\mathrm{m} / \mathrm{d}) \quad$ value:
C Saturation

Capillary pressure curve model

$C$ Brooks and Corey

- van Genuchten

Brooks and Corey's lambda .... 0

Air entry head $[\mathrm{m}]$. . . . . . . . . 0

Residual water saturation . . . . . 0.065

van Genuchten's alpha $[1 / \mathrm{m}]$. . . 0.21

van Genuchten's n . . . . . . . 3.7
Data file:

C: UHSSMITANQUE1.DAT

$\checkmark$ Enable range checking

OK

\section{POROUS MEDIUM PROPERTIES}

Sat'd vert. hydraulic cond. (m/d) . .6.9

Ratio of horz/vert hyd. cond. . . . 1

Porosity . . . . . . . . . . . 0.38

Bulk density $\left[\mathrm{g} / \mathrm{cm}^{3}\right]$. . . . . . . 1.64

Aquifer saturated thickness (m) . . 10

Depth to water table (m) . . . . . . 50

Capillary thickness parameter [m] . .1

Groundwater gradient $[\mathrm{m} / \mathrm{m}]$. . . . . 033

Longitudinal dispersivity (m] . . . 1

Transverse dispersivity (m) . . . . . 1

Vertical dispersivity (m) . . . . . 1

Figura 3.11 - Imagem da janela para inserir os dados hidrológicos. 
Viscosidade dinâmica da água (cp)

Para essa temperatura de $20^{\circ} \mathrm{C}$, a viscosidade da água é $1,0 \mathrm{cp}$ (centipoise).

Densidade da água $\left(\mathrm{g} / \mathrm{cm}^{3}\right)$

A densidade da água a $20^{\circ} \mathrm{C}$ é de $1,0 \mathrm{~g} / \mathrm{cm}^{3}$.

$\underline{\text { Tensão superficial da água (dyne/cm) }}$

Para a temperatura de $20^{\circ} \mathrm{C}$ a tensão superficial da água pura é de $72,8 \mathrm{dyne} / \mathrm{cm}$. Porém o manual do programa indica que um menor valor seja mais apropriado para a água contida no solo e/ou em locais contaminados. Este valor é de $65 \mathrm{dyne} / \mathrm{cm}$ e foi adotado para a simulação.

\section{Máxima permeabilidade relativa da água durante a infiltração}

Durante a infiltração, a permeabilidade do solo é menor que a permeabilidade saturada, devido à presença de ar que fica preso nos poros. O valor típico para este parâmetro indicado no manual do programa é de 0,5 , mas pelo fato de ser uma simulação do caso de um local com maior controle das condições, o valor adotado foi de 0,7 .

\section{$\underline{\text { Recarga }}$}

O valor deste parâmetro depende da situação do local. No caso deste estudo, foi utilizada a opção de saturação constante, sendo o valor mínimo para o primeiro ensaio (valor da saturação residual obtida pela curva de retenção), sem recarga, pois não foi simulada a precipitação no ensaio de modelo físico. Para o segundo ensaio, foi considerada a saturação de $30 \%$, que é a média da saturação da zona vadosa (determinada a partir de amostras coletadas no local). $O$ terceiro ensaio também tem a saturação considerada como a média da saturação das camadas coletadas do local, que é de $20 \%$. 


\section{Modelo da curva de pressão capilar (curva de retenção)}

O modelo utilizado foi o de van Genuchten

- Saturação de água residual, $\mathrm{S}_{\mathrm{wr}}$

- $\alpha$ de van Genuchten

- $\mathrm{n}$ de van Genuchten

Os três parâmetros acima foram obtidos a partir do ensaio com a placa de sucção, e os valores foram: $S_{w r}=0,065, \alpha=0,21$ e $n=3,7$.

\subsubsection{Propriedades do meio poroso}

\section{Condutividade hidráulica vertical saturada $(\mathrm{m} / \mathrm{d})$}

A condutividade hidráulica saturada vertical para o solo, com 0,61 de índice de vazios, é de $8 \mathrm{E}-4 \mathrm{~m} / \mathrm{s}$, que convertido para $\mathrm{m} /$ dia, é de $6,9 \mathrm{~m} /$ dia.

\section{$\underline{\text { Relação da condutividade hidráulica horizontal para a vertical }}$}

Por simplificação, foi adotado que o solo seja homogêneo, portanto a relação de condutividade horizontal com a vertical é de 1,0.

\section{Porosidade}

A porosidade para um solo com índice de vazios de 0,61 é de 0,38.

\section{Densidade seca $\left(\mathrm{g} / \mathrm{cm}^{3}\right)$}

A densidade seca do solo em questão é de $1,64 \mathrm{~g} / \mathrm{cm}^{3}$.

\section{Espessura do aquífero saturado (m)}

Foi considerado que a espessura do aquífero saturado seja de $0,5 \mathrm{~m}$.

\section{Profundidade do nível d'água $(\mathrm{m})$}

A profundidade do nível da água em relação à fonte de contaminação varia de acordo com o tipo de ensaio, onde no primeiro foi considerado como $50 \mathrm{~m}$, para garantir que haja pouca influência; para o segundo ensaio foi de $1 \mathrm{~m}$, de acordo com o tanque experimental; e o terceiro tanque foi considerado como $2 \mathrm{~m}$, por ajustes do modelo. 


\section{Parâmetro de espessura da capilaridade $(\mathrm{m})$}

O valor utilizado foi de 0,1 m, tendo em vista que o valor de entrada de ar é por volta de $1 \mathrm{kPa}$.

\section{Gradiente do aquífero $(\mathrm{m} / \mathrm{m})$}

O gradiente horizontal do aquífero utilizado foi de $0,033 \mathrm{~m} / \mathrm{m}$, que é o gradiente do segundo ensaio.

\section{Dispersividade longitudinal, transversal e vertical do aquífero (m)}

Por falta de dados sobre a dispersividade do aquífero, e pelo fato de este parâmetro não ser muito importante, pois está sendo considerado que não há dissolução do NAPL na água, foi considerado como iguais.

\subsubsection{Propriedades da fase de hidrocarbonetos}

\section{Hydrocarbon Phase Parameters}

\section{HYDROCARBON PHASE PROPERTIES}

NAPL density $\left[\mathrm{g} / \mathrm{cm}^{3}\right]$

.... .852

NAPL dynamic viscosity (cp). . . . 8.5

Hydrocarbon solubility (mg/L) . . . . .00001

Aquifer residual NAPL saturation. . 5

Vadose zone residual NAPL sat'n. . 1

Soil/water partition coeff. $[\mathrm{L} / \mathrm{kg}]$. . 0001

NAPL surface tension $[$ dyne/cm]. . 48.3

\section{DISSOLVED CONSTITUENT PROPERTIES}

$\Gamma$ Dissolved constituent exists

Initial constit. conc. in NAPL NAPL/water partition coefficient. .

Soil/water partition coeff. $[\mathrm{L} / \mathrm{kg}]$. . 0

Constituent solubility (mg/L] . . . . . 0

$\Gamma$ Constit. 1 -life in aquifer (d) . . 0.0

\section{Data file:} C: IHSSMITANQUE3.DAT

$\varpi$ Enable range checking

OK

\section{Cancel}

\section{-HYDROCARBON RELEASE}

$C$ specified flux

- Specified volume/area

$C$ Constant head ponding

$C$ Variable ponding after const head period

NAPL flux $(\mathrm{m} / \mathrm{d}) \ldots \ldots \ldots \ldots$

Beginning time [d] ....... 0

Ending time [d] . . . . . . . 0

Ponding depth $(\mathrm{m}) \ldots \ldots \ldots . . . .0$

NAPL yolume/area (m). . . . . 262

Lower depth of NAPL zone (m). 0.25

Figura 3.12 - Imagem da janela para inserir os dados da fase do hidrocarboneto.

\section{Densidade do NAPL $\left(\mathrm{g} / \mathrm{cm}^{3}\right)$}

De acordo com dados da fabricante, a densidade do óleo utilizado é de $0,852 \mathrm{~g} / \mathrm{cm}^{3}$.

Viscosidade dinâmica do NAPL (cp)

A viscosidade dinâmica do óleo é de $8,5 \mathrm{cp}$ de acordo com a fabricante. 


\section{Solubilidade do hidrocarboneto (NAPL) (mg/L)}

De acordo com o fabricante do óleo, a solubilidade na água é despresível. Valor adotado foi de $0,00001 \mathrm{mg} / \mathrm{L}$, pois não é possível deixar como zero. Este parâmetro é utilizado como dado para saber o final da simulação do modelo OILENS.

\section{Saturação residual do NAPL no aquífero}

A obtenção dos valores da saturação residual no aquífero e na zona vadosa é de grande dificuldade, pois necessitariam um ensaio em que fosse obtida a curva de pressão capilar entre o ar e o NAPL, sendo que uma parte dos poros estaria preenchida com água. Com os ensaios com o papel filtro não foi possível obter um valor de referência, por isso, para a simulação, o valor considerado para este parâmetro foi de 0,5 por indicação no manual do programa.

\section{Saturação residual do NAPL na zona vadosa}

Pelos valores obtidos pela análise das amostras coletadas no tanque experimental, foi considerado o valor de 0,1.

\section{Coeficiente de partição solo/água (L/kg)}

O coeficiente foi estimado como 0,00001 por considerar que não há diluição do NAPL na água.

\section{$\underline{\text { Tensão superficial do NAPL (dyne/cm) }}$}

De acordo com o fabricante, a tensão superficial é 48,3 dyne/cm.

\section{Propriedades dos constituintes dissolvidos}

Foi considerado que não há dissolução do óleo devido às características do mesmo.

\subsubsection{Disposição do hidrocarboneto (NAPL)}

O tipo de disposição de hidrocarboneto é o de volume/área especificado, que em todos os ensaios foi de 15 litros na área de $0,0573 \mathrm{~m}^{2}$ (tubo de $27 \mathrm{~cm}$ de diâmetro).

Parâmetros de disposição

Volume/área do NAPL (m) 
Calculando 15 litros pela área de 0,0573, temos 0,262.

Profundidade da disposição (m)

A profundidade de disposição em todos os casos foi de $25 \mathrm{~cm}$ da superfície (altura do tubo).

\subsubsection{Parâmetros de controle da simulação}

\begin{tabular}{|c|c|c|c|c|c|}
\hline \multicolumn{2}{|l|}{ 1. Simulation Parameters } & \multicolumn{3}{|c|}{ 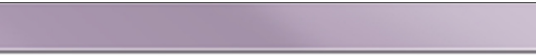 } & $\mathrm{x}$ \\
\hline \multicolumn{2}{|c|}{ SIMULATION CONTROL PARAMETERS } & \multirow{3}{*}{\multicolumn{3}{|c|}{$\begin{array}{l}\text { Data file: } \\
\text { C: IHSSH } \\
\sqrt{\checkmark} \text { Enable range checking }\end{array}$}} & \multirow[t]{2}{*}{ OK } \\
\hline \multicolumn{2}{|c|}{ Radius of NAPL lens source (m). . . .135 } & & & & \\
\hline Radius multiplication factor . . . . . & 1.001 & & & & של \\
\hline Max NAPL saturation in NAPL lens. & .5 & & & & \\
\hline Simulation ending time [d] . . . . . & 10000 & NAPL LENS PBDF & & & \\
\hline Maximum solution time step [d] ... & 24 & Fartertime (d) for & & 1 & \begin{tabular}{|l|l} 
\\
\end{tabular} \\
\hline $\begin{array}{l}\text { Minimum time between printed time } \\
\text { steps [d] }\end{array}$ & .25 & $\begin{array}{l}\text { Enter time [d] for } \\
\text { each of up to }\end{array}$ & & $\begin{array}{l}2 \\
3\end{array}$ & \begin{tabular}{|l|}
5 \\
10 \\
\end{tabular} \\
\hline -DIENS Simulation ending criterion & & IU profiles & & 4 & 20 \\
\hline [ULENS Simulation ending criterion & & & & 5 & 40 \\
\hline User-specilıed time & & Number of & & 6 & 100 \\
\hline NAPL lens spreading stops & & profiles & & 7 & \\
\hline$C$ Max contaminant mass flux into & o aquifer & & & 8 & \\
\hline$C$ Contaminant leached from lens & & & & 9 & \\
\hline Fraction of mass remaining .... & & & & 10 & \\
\hline HSSH-T MODFI PABAHFI & TFRS & RECEPTOR WELL & & $X[\mathrm{~m}]$ & $Y[\mathbf{m}]$ \\
\hline & & & 1 & $\mathbf{0}$ & $\mathbf{0}$ \\
\hline Percent max. contam't radius $[\%] .$. & 101 & Enter coordinates & 2 & & \\
\hline Minimum output conc'n $[\mathrm{mg} / \mathrm{L}] \ldots$. & .001 & for each of up to & 3 & & \\
\hline Beginning time $[d] \ldots \ldots \ldots$ & 0.01 & & 4 & & \\
\hline Ending time [d] $\ldots \ldots \ldots \ldots \ldots$ & 10000 & & 5 & & \\
\hline Time increment $[d] \ldots . . . . .$. & 10 & $\begin{array}{l}\text { Number or } \\
\text { wells }\end{array}$ & 6 & & \\
\hline
\end{tabular}

Figura 3.13 - Imagem da janela para inserir dados para controle da simulação.

$\underline{\text { Raio da fonte da lente de óleo (m) }}$

O diâmetro do tubo é de $27 \mathrm{~cm}$, portanto o raio é $0,135 \mathrm{~m}$.

\section{Fator multiplicador do raio}

Fator utilizado para corrigir erros singulares do programa. Foi adotado o valor de 1,001 pela recomendação do programa.

Saturação máxima de NAPL na lente de NAPL 
O valor foi estimado como 0,8 para o caso da areia seca, e 0.7 para os outros dois ensaios, devido à presença da água.

\section{Final da Simulação (d)}

A simulação nos três casos será finalizada depois de 50 dias.

$\underline{\text { Intervalo de solução máxima (d) }}$

Por recomendação no manual do programa o intervalo adotado foi de $25 \mathrm{~d}$.

$\underline{\text { Tempo mínimo entre os intervalos e para checagem do balance de massa (d) }}$

Por indicação do programa o intervalo adotado foi de $0,25 \mathrm{~d}$.

Parâmetro que varia de acordo com o ensaio. Foram 11 dias para o primeiro ensaio, 30 dias para o segundo e 42 dias para o terceiro. 


\section{Resultados e Análises}

4.1 Ensaios de laboratório

A seguir estão apresentados os resultados e análises dos ensaios realizados no laboratório.

4.1.1 Curva de retenção matricial com água

Os dados obtidos no ensaio da curva de retenção de água e o ajuste da curva pela equação de Van Genuchten estão na Figura 3.3. Pode ser notado que a sucção correspondente a entrada de ar é $1 \mathrm{kPa}$.

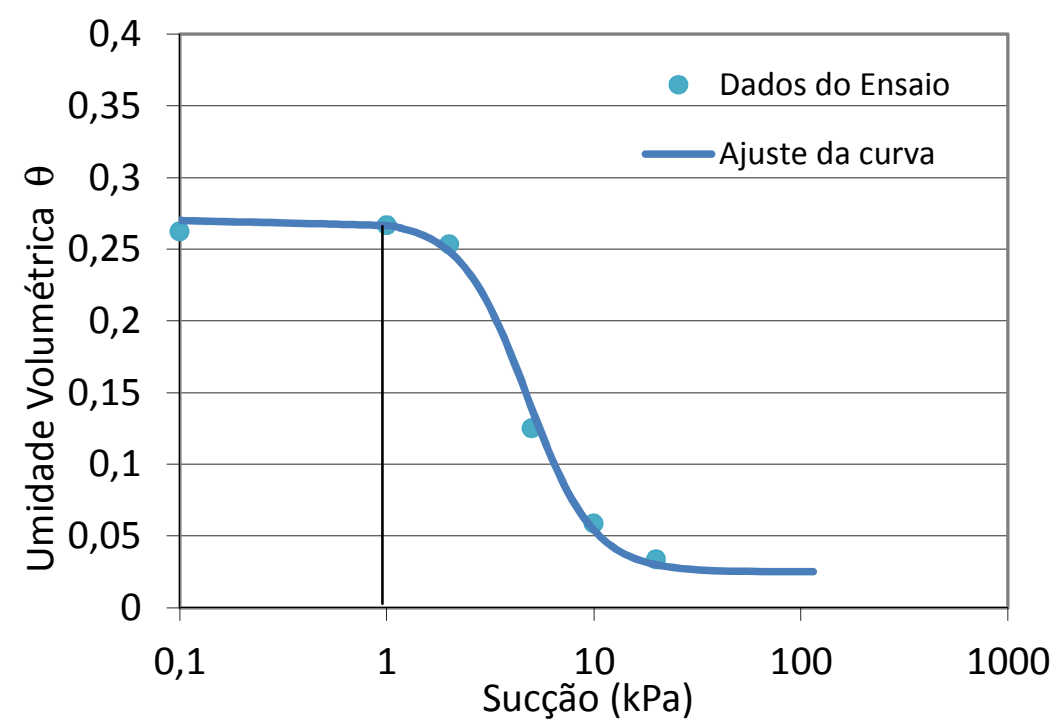

Figura 4.1 - Curva característica da areia de Itapetininga.

A Tabela 4.1 apresenta os parâmetros obtidos a partir do ajuste da curva pela equação de van Genuchten.

Tabela 4.1 - Parâmetros da Curva de Retenção.

\begin{tabular}{c|c|c|c|c}
$\theta_{\text {sat }}$ & $\theta_{\mathrm{r}}$ & $\alpha$ & $\mathrm{n}$ & $\mathrm{m}$ \\
\hline 0,27 & 0,025 & 0,21 & 3,7 & 0,73
\end{tabular}


Substituindo os parâmetros obtidos na equação (2.9), temos:

$$
\theta=0,025+\frac{(0,27-0,025)}{\left[1+(0,21 \Psi)^{3,7}\right]^{0,73}}
$$

\subsubsection{Curva de retenção com óleo}

Analisando os dados obtidos do corpo de prova CP41 (O20), foi observado que o peso do corpo de prova não varia ao longo do experimento, indicando que o óleo não evapora nas condições de armazenamento das amostras. Com isso, foi considerada neste ensaio, a perda de peso do corpo de prova é devida exclusivamente a evaporação da água presente na amostra.

As Figuras 4.2, 4.3, 4.4 e 4.5 apresentam os resultados dos ensaios com o papel filtro das amostras com $2 \%, 5 \%, 10 \%$, e $15 \%$ de óleo respectivamente, executados no recipiente cerâmico.

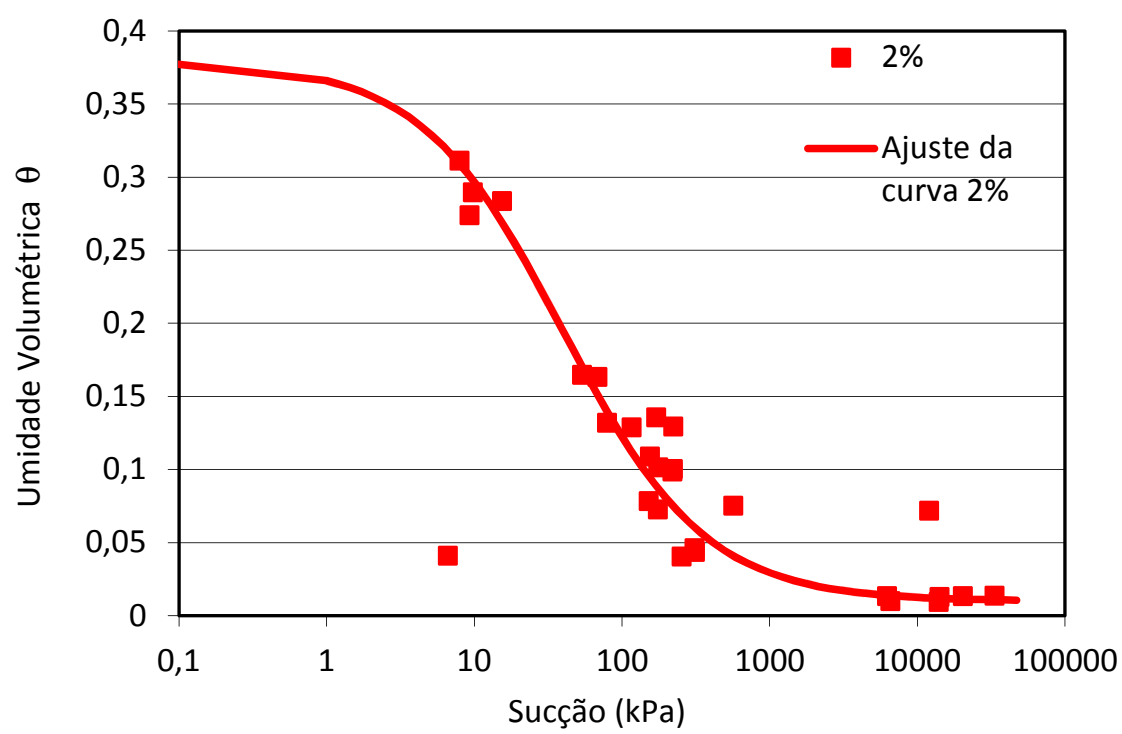

Figura 4.2 - Curva de retenção com $2 \%$ de óleo. 


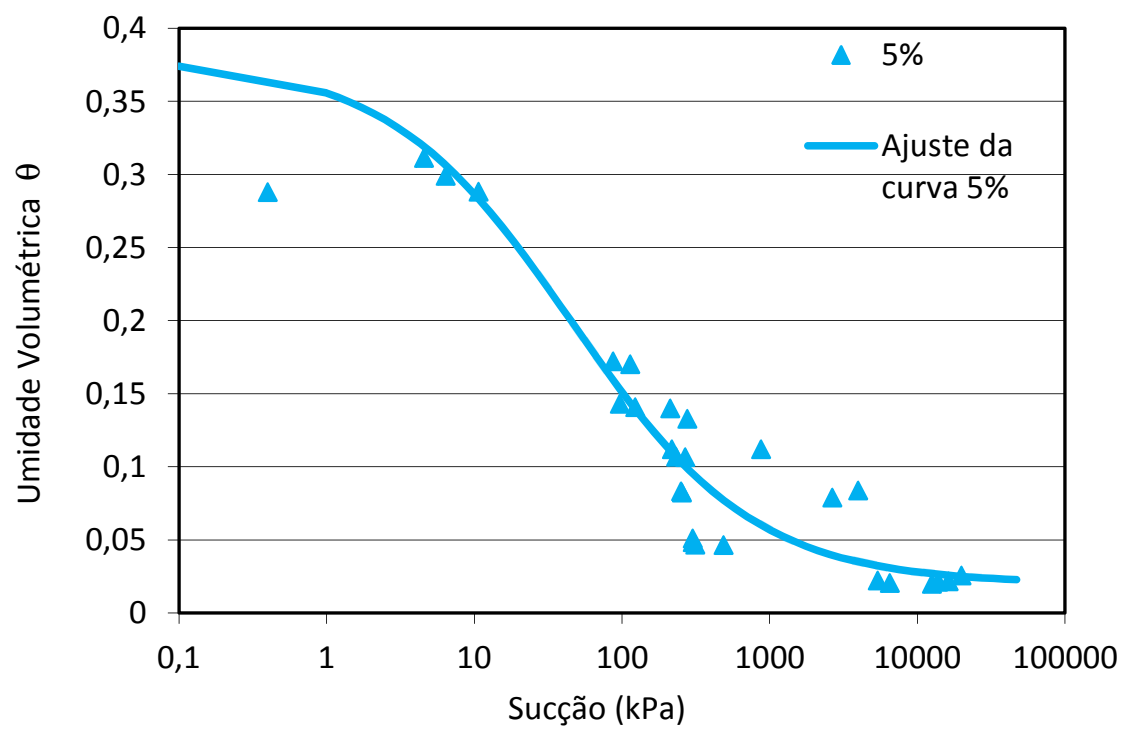

Figura 4.3 - Curva de retenção com 5\% de óleo.

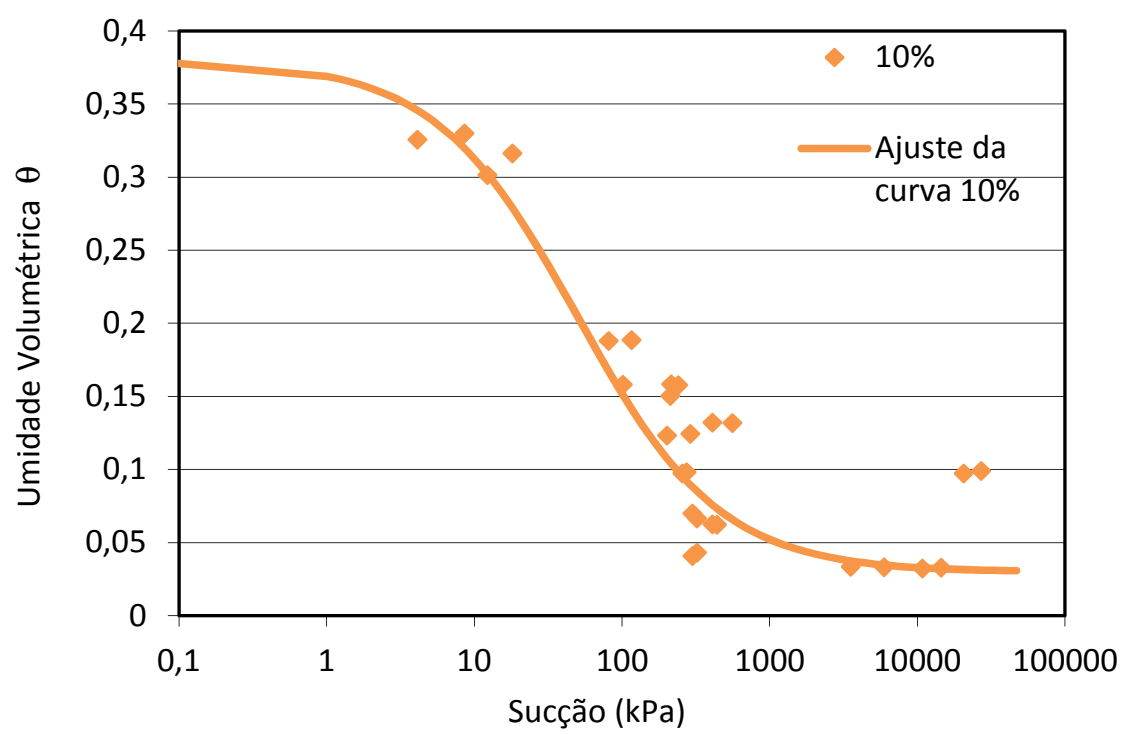

Figura 4.4 - Curva de retenção com 10\% de óleo. 


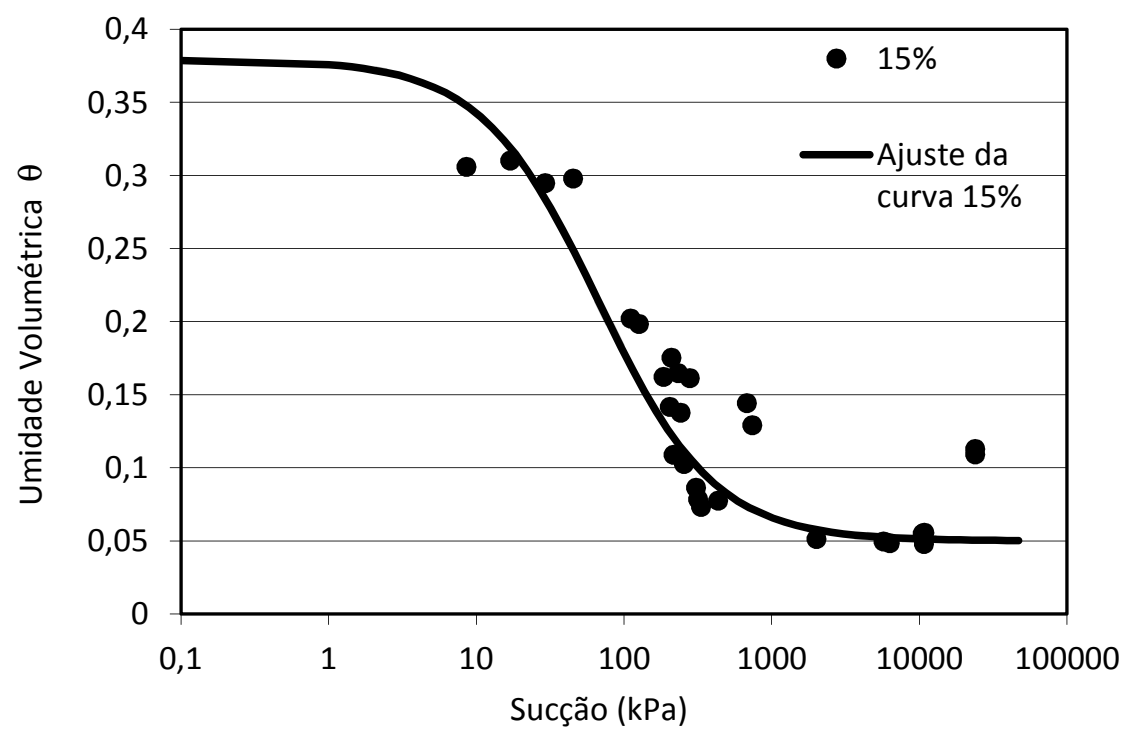

Figura 4.5 - Curva de retenção com 15\% de óleo.

Os parâmetros de ajuste das curvas de retenção estão apresentados na Tabela 4.2 a seguir:

Tabela 4.2 - Parâmetros das curvas de retenção com óleo

\begin{tabular}{c|c|c|c|c|c} 
& $\theta_{\text {sat }}$ & $\theta_{\mathrm{r}}$ & $\alpha$ & $\mathrm{n}$ & $\mathrm{m}$ \\
\hline $2 \%$ & 0,3789 & 0,01 & 0,025 & 1,9 & 0,47 \\
\hline $5 \%$ & 0,3789 & 0,02 & 0,022 & 1,7 & 0,41 \\
\hline $10 \%$ & 0,3789 & 0,03 & 0,02 & 1,9 & 0,47 \\
\hline $15 \%$ & 0,3789 & 0,05 & 0,015 & 2,1 & 0,52
\end{tabular}

O valor de umidade volumétrica de saturação foi calculado a partir índice de vazios $(e=0,61)$. 


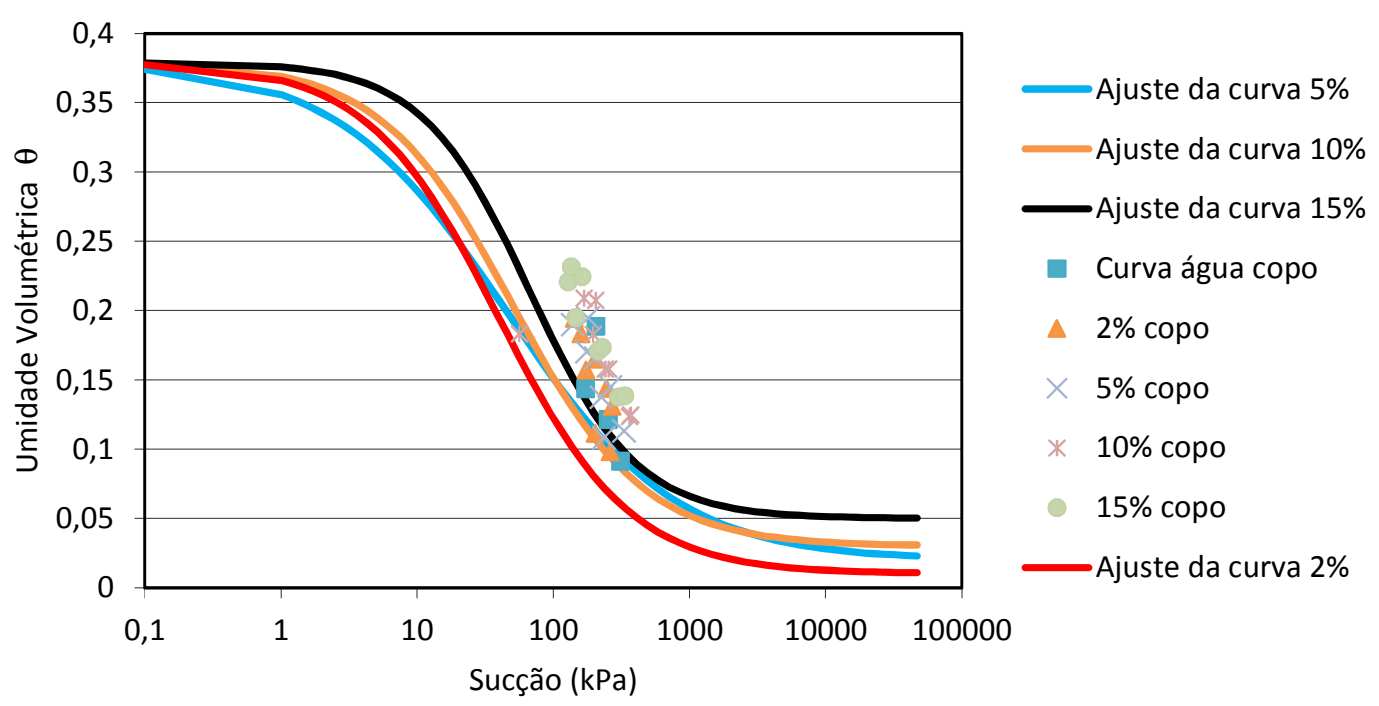

Figura 4.6 - Comparação entre as curvas do recipiente cerâmico com as de vidro

Comparando os gráficos da Figura 4.6 acima, percebe-se que a umidade volumétrica residual aumenta de acordo com a quantidade de óleo presente no solo nas amostras de 2\%, 5\%, 10\% e 15\%. Isso provavelmente ocorre porque, nas condições de ensaio, o óleo não evapora, permanecendo no solo.

Ainda na mesma figura, está a comparação entre os dados obtidos no ensaio com o recipiente cerâmico e com o de vidro. Nota-se que os pontos obtidos do recipiente de vidro não seguem a mesma tendência que as de cerâmica. Isso pode ter ocorrido devido à diferença na altura e diâmetro do corpo de prova, onde os copos de vidro possuem o diâmetro menor, deixando o corpo de prova com altura maior.

Comparando o comportamento dos pontos obtidos com o recipiente de vidro ainda na Figura 4.6, observamos que não é possível diferenciar os pontos de acordo com a concentração de óleo.

Foi observado que é muito difícil manter uma amostra com o grau de saturação perto do máximo, pois os corpos de prova que foram colocados para a estabilização do papel filtro com a umidade perto da saturação, que necessitam cerca de 40 dias de espera, foi notado que depois desse período a umidade já não estava mais perto da saturação. 
Depois do ensaio de curva de retenção, foram coletadas amostras dos corpos de prova para a análise no HATR-T2 com o objetivo de quantificar o óleo presente na amostra e verificar a uniformidade da concentração de óleo ao longo da amostra. Para isso, foram coletadas amostras dos corpos de prova CP 06, 07, 08 e 09, que as concentrações iniciais eram 10\%,15\%, 15\% e 2\%, respectivamente. A Tabela 4.3 apresenta os resultados:

Tabela 4.3 - Verificação da existência de gradiente de óleo no corpo de prova

\begin{tabular}{c|c|c|c|c} 
Amostra & $\begin{array}{c}\text { Profundidade } \\
(\mathrm{cm})\end{array}$ & $\begin{array}{c}\text { Leitura média } \\
(\mathrm{AbS})\end{array}$ & $\begin{array}{c}\text { Concentração } \\
(\mathrm{ppm})\end{array}$ & $\begin{array}{c}\text { Concentração } \\
(\%)\end{array}$ \\
\hline \multirow{2}{*}{$\begin{array}{c}\text { CP } 06 \\
10 \% \text { de oleo }\end{array}$} & 0 a 0,7 & 142 & 7459 & 0,74 \\
\cline { 2 - 5 } & 0,7 a 1,4 & 159 & 8282 & 0,83 \\
\cline { 2 - 5 } CP 07 & 1,4 até o fundo & 163 & 8575 & 0,86 \\
\cline { 2 - 5 } 15\% de oleo & 0,7 a 1,4 & 251 & 29404 & 2,94 \\
\cline { 2 - 5 } & 1,4 até o fundo & 244 & 29130 & 2,91 \\
\hline \multirow{2}{*}{ CP 08 } & 0 a 1,0 & 200 & 16490 & 2,79 \\
\cline { 2 - 5 } $15 \%$ de oleo & 1 a 1,7 & 241 & 27537 & 2,75 \\
\cline { 2 - 5 } & 1,7 até o fundo & 230 & 24666 & 2,46 \\
\hline \multirow{2}{*}{ CP 09 } & 0 a 0,7 & 20 & 848 & 0,08 \\
\cline { 2 - 5 } $2 \%$ de óleo & 0,7 a 1,4 & 23 & 938 & 0,09 \\
\cline { 2 - 5 } & 1,4 até o fundo & 21 & 909 & 0,09
\end{tabular}

A partir dos dados da Tabela 4.3, observa-se que, nas concentrações analisadas, não ocorre o deslocamento vertical de óleo.

Estes dados também destacam o fato citado por Nascimento et al. (2008), que o aparelho InfraCal não é uma ferramenta confiável para a quantificação de óleo presente no solo. 
4.2 Ensaio com o modelo físico

\subsubsection{Primeiro ensaio}

Posicionado o tubo guia, foi iniciado o primeiro derramamento de óleo. Foram despejados 15 litros de óleo. Foram 53 minutos até que todo o óleo contido no tubo infiltrasse no solo.

O Anexo II apresenta a sequência de fotos com horário e detalhe da profundidade do óleo no tubo guia.

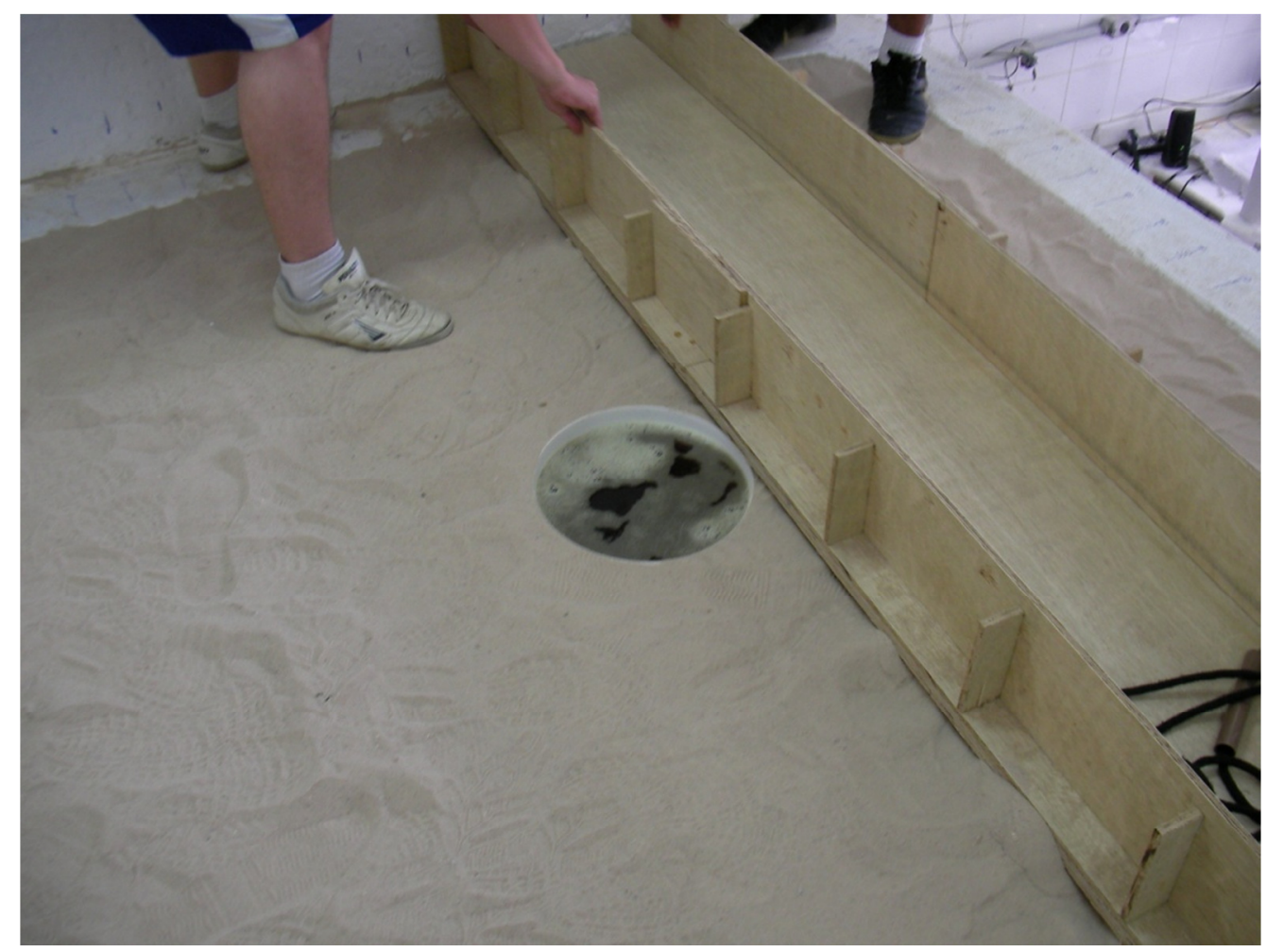

Figura 4.7 - Início do derramamento de óleo.

Depois de onze dias do derramamento, foi iniciada a coleta de amostras do solo contaminado. Para isto, o tanque foi dividido em camadas na vertical de $20 \mathrm{~cm}$ cada, totalizando sete camadas. Cada camada foi dividida em células de acordo com a Figura 4.8. A numeração das células foi ordenada de maneira a facilitar a organização das amostras coletadas. 


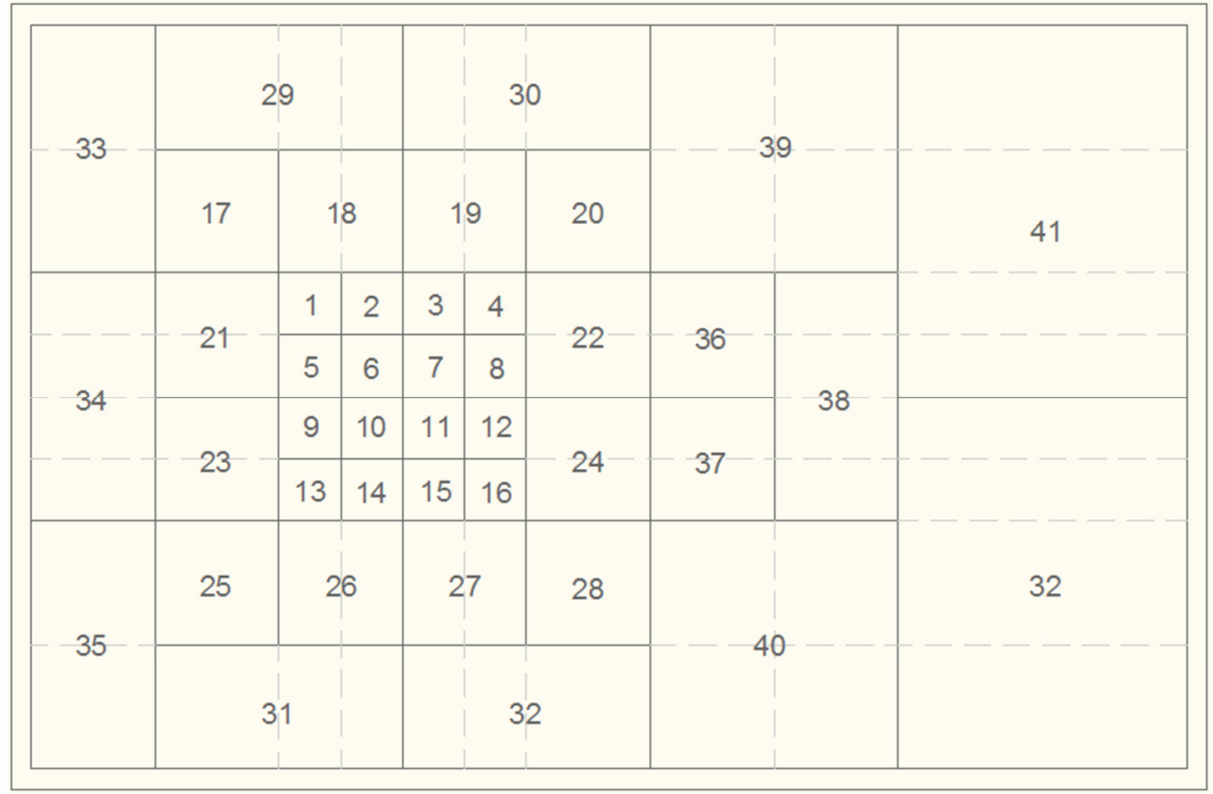

Figura 4.8 - Disposição das amostras retiradas.

Para cada camada de $20 \mathrm{~cm}$ foram retiradas amostras e armazenadas em recipientes de vidro e com tampa (Fig. 4.9). Estas amostras foram para o laboratório, onde foram analisadas com o espectrofotômetro de infravermelho, para saber a concentração de óleo contida na amostra.

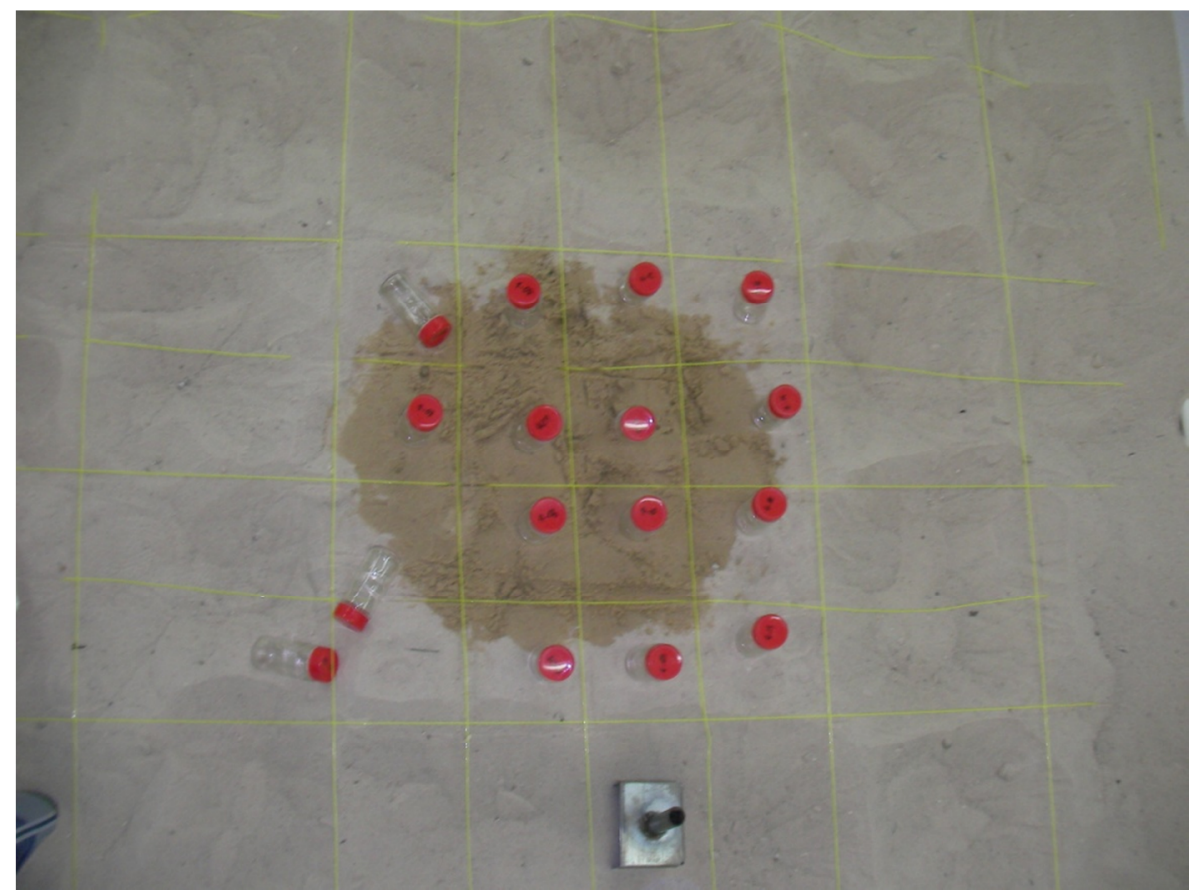

Figura 4.9 - Retirada de amostras e armazenamento em recipientes de vidro com tampa. 
Com a coleta de amostras, foi observado que a pluma tem formato cilíndrico, com o diâmetro aproximado de $50 \mathrm{~cm}$. A quantidade de óleo derramado não foi suficiente para atingir o fundo do tanque experimental, formando no fundo da pluma uma semiesfera (Fig. 4.10).

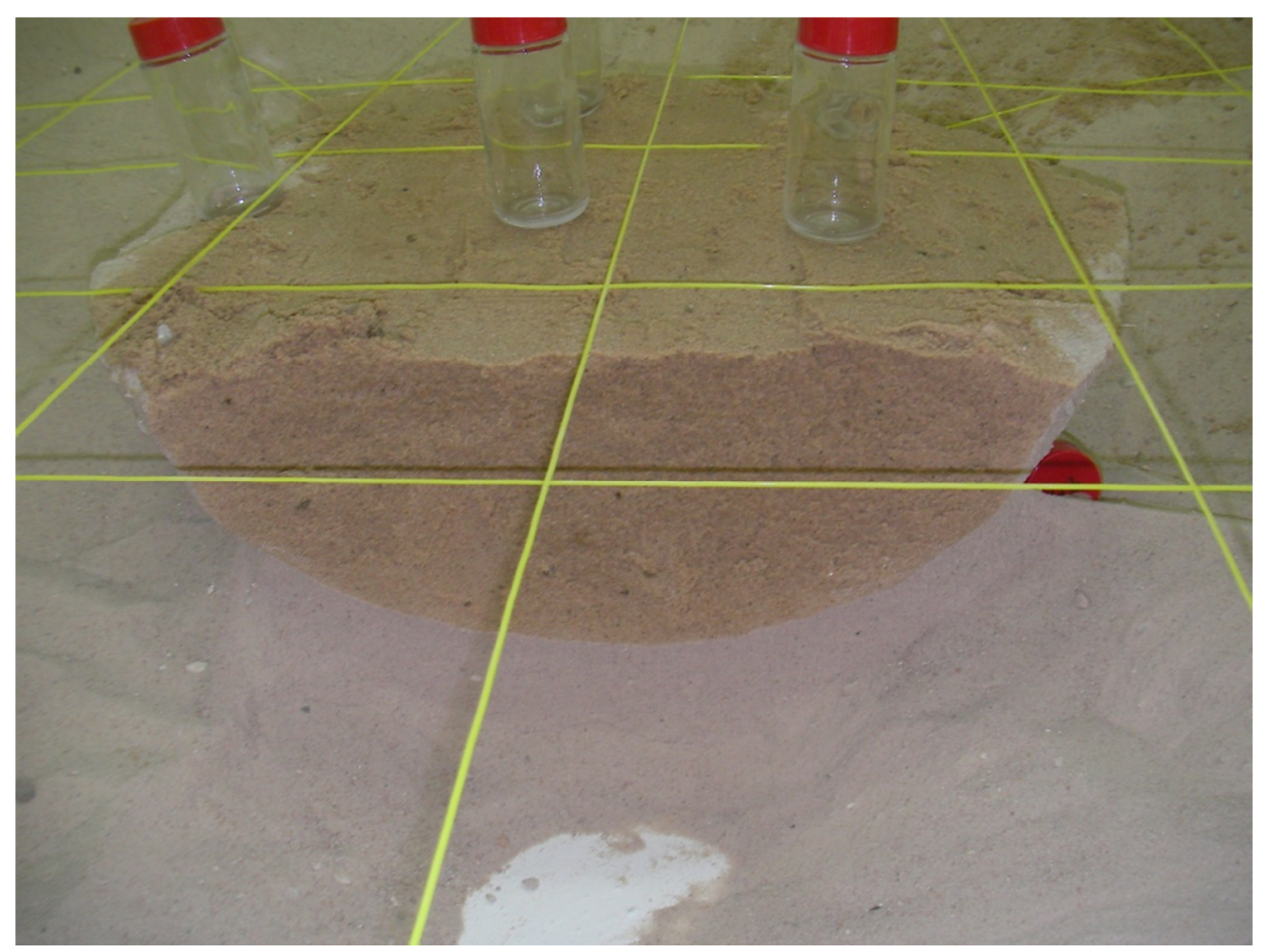

Figura 4.10 - Parte inferior da pluma de óleo.

\subsubsection{Segundo ensaio}

Com o sistema de nível d'água estabilizado, foi executado o segundo ensaio de derramamento de óleo. Pelo fato do solo estar úmido, o tempo para que o óleo presente no tubo infiltrasse no solo foi cerca de 1 hora e 50 minutos, mais que duas vezes o tempo necessário para a infiltração em solo seco.

Depois de trinta dias, as amostras de solo foram coletadas de modo semelhante ao primeiro ensaio. O nível d'água foi rebaixado aos poucos, de acordo com a profundidade de onde estava sendo coletada a amostra. Desta vez não foi possível observar claramente a pluma de contaminação, pois não era possível diferenciar onde estava molhado com água ou com óleo (Fig. 4.11). 


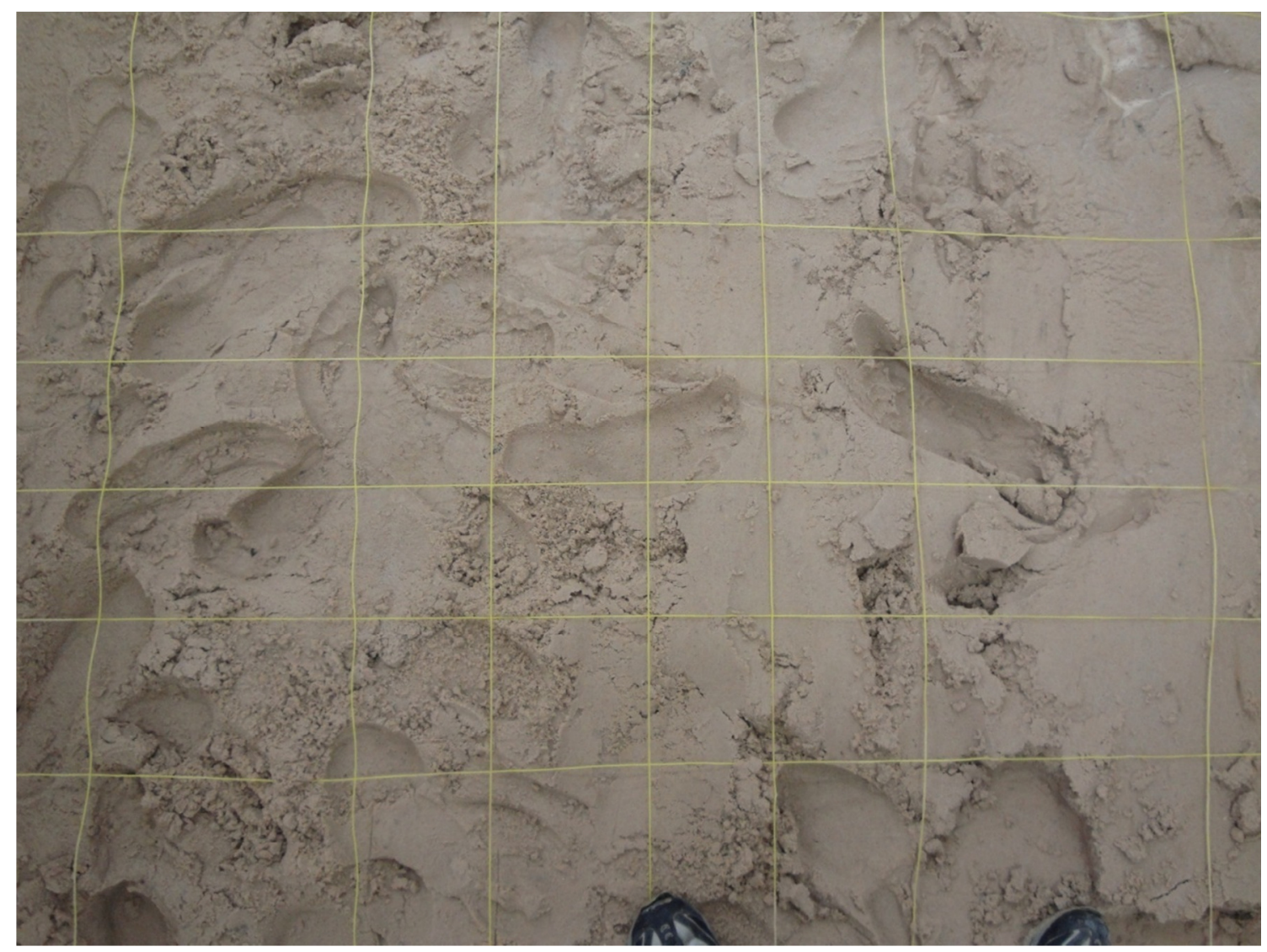

Figura 4.11 - Coleta de amostras no segundo ensaio

\subsubsection{Terceiro ensaio}

No terceiro ensaio, com o solo apenas úmido, mas sem nível de água, foi executado o terceiro derramamento. Com o comportamento semelhante ao segundo ensaio, o tempo necessário para que o óleo contido no tubo (15 litros) foi de 1 hora e 40 minutos.

Desta vez foram 42 dias para esperar a estabilização da pluma. No 42 으 dia foi iniciada a coleta de amostras de solo contaminado, mas desta vez o tanque foi divido em cinco camadas, sendo a primeira coletada na profundidade entre 25 a $30 \mathrm{~cm}$, e as quatro seguintes a cada 25 centímetros. Foi notado a existência de uma pequena camada de água no fundo do tanque, com cerca de $10 \mathrm{~cm}$ de espessura. 
As amostras de solo contaminado foram analisadas no Laboratório de Mecânica dos Solos da Escola Politécnica da Universidade de São Paulo. O solvente utilizado neste ensaio foi reciclado pelo Laboratório de Solventes do Instituto de Química da USP.

As amostras foram analisadas de acordo com o procedimento descrito no capítulo anterior. As Tabelas 4.4, 4.5 e 4.6 apresentam os resultados da análise das amostras do primeiro, segundo e terceiro ensaio no tanque experimental respectivamente.

Tabela 4.4 - Resultado da análise das amostras do primeiro ensaio

\begin{tabular}{|c|c|c|c|c|}
\hline Camada & Profundidade & Amostra & $\begin{array}{l}\text { ppm de Óleo } \\
\text { na Amostra }\end{array}$ & $\begin{array}{c}\text { \% de Óleo na } \\
\text { Amostra }\end{array}$ \\
\hline 1 & 0 a $20 \mathrm{~cm}$ & 22 & 0 & 0,0 \\
\hline \multirow{13}{*}{2} & \multirow{13}{*}{20 a $40 \mathrm{~cm}$} & 1 & 1590 & 0,2 \\
\hline & & 3 & 25356 & 2,5 \\
\hline & & 4 & 20000 & 2,0 \\
\hline & & 5 & 13134 & 1,3 \\
\hline & & 7 & 6819 & 0,7 \\
\hline & & 8 & 25800 & 2,6 \\
\hline & & 9 & 7455 & 0,7 \\
\hline & & 10 & 20000 & 2,0 \\
\hline & & 12 & 20000 & 2,0 \\
\hline & & 14 & 20000 & 2,0 \\
\hline & & 15 & 7888 & 0,8 \\
\hline & & 21 & 0 & 0,0 \\
\hline & & 24 & 0 & 0,0 \\
\hline \multirow{13}{*}{3} & \multirow{13}{*}{40 a $60 \mathrm{~cm}$} & 2 & 20000 & 2,0 \\
\hline & & 4 & 20000 & 2,0 \\
\hline & & 5 & 20000 & 2,0 \\
\hline & & 6 & 21765 & 2,2 \\
\hline & & 7 & 20000 & 2,0 \\
\hline & & 11 & 43668 & 4,4 \\
\hline & & 12 & 36520 & 3,7 \\
\hline & & 13 & 11440 & 1,1 \\
\hline & & 14 & 35509 & 3,6 \\
\hline & & 15 & 20000 & 2,0 \\
\hline & & 21 & 0 & 0,0 \\
\hline & & 24 & 0 & 0,0 \\
\hline & & 30 & 0 & 0,0 \\
\hline \multirow{6}{*}{4} & \multirow{6}{*}{60 a $80 \mathrm{~cm}$} & 2 & 5273 & 0,5 \\
\hline & & 8 & 31620 & 3,2 \\
\hline & & 4 & 8330 & 0,8 \\
\hline & & 5 & 8169 & 0,8 \\
\hline & & 7 & 20000 & 2,0 \\
\hline & & 10 & 13145 & 1,3 \\
\hline
\end{tabular}




\begin{tabular}{|c|c|c|c|c|}
\hline & & 11 & 46579 & 4,7 \\
\hline & & 12 & 20000 & 2,0 \\
\hline & & 13 & 0 & 0,0 \\
\hline & & 15 & 20000 & 2,0 \\
\hline & & 21 & 0 & 0,0 \\
\hline & & 24 & 0 & 0,0 \\
\hline & & 30 & 0 & 0,0 \\
\hline \multirow{8}{*}{5} & \multirow{8}{*}{80 a $100 \mathrm{~cm}$} & 1 & 0 & 0,0 \\
\hline & & 3 & 45925 & 4,6 \\
\hline & & 7 & 20000 & 2,0 \\
\hline & & 9 & 20000 & 2,0 \\
\hline & & 12 & 20000 & 2,0 \\
\hline & & 14 & 6083 & 0,6 \\
\hline & & 15 & 20000 & 2,0 \\
\hline & & 24 & 0 & 0,0 \\
\hline \multirow{9}{*}{6} & \multirow{9}{*}{100 a $120 \mathrm{~cm}$} & 3 & 29565 & 3,0 \\
\hline & & 2 & 20000 & 2,0 \\
\hline & & 5 & 20000 & 2,0 \\
\hline & & 6 & 52664 & 5,3 \\
\hline & & 7 & 20000 & 2,0 \\
\hline & & 13 & 0 & 0,0 \\
\hline & & 15 & 20000 & 2,0 \\
\hline & & 16 & 20000 & 2,0 \\
\hline & & 19 & 0 & 0,0 \\
\hline \multirow{11}{*}{7} & \multirow{11}{*}{$\begin{array}{l}120 \mathrm{~cm} \text { até o } \\
\text { fundo }\end{array}$} & 2 & 11703 & 1,2 \\
\hline & & 4 & 0 & 0,0 \\
\hline & & 6 & 31639 & 3,2 \\
\hline & & 8 & 17344 & 1,7 \\
\hline & & 9 & 0 & 0,0 \\
\hline & & 10 & 54746 & 5,5 \\
\hline & & 11 & 20000 & 2,0 \\
\hline & & 14 & 9506 & 1,0 \\
\hline & & 15 & 10865 & 1,1 \\
\hline & & 16 & 0 & $\overline{0,0}$ \\
\hline & & 26 & 0 & 0,0 \\
\hline
\end{tabular}

Tabela 4.5 - Resultado da análise das amostras do segundo ensaio $\begin{array}{ccc}\text { Camada Profundidade Amostra } & \begin{array}{c}\text { ppm de Óleo } \\ \text { na Amostra }\end{array} \quad \begin{array}{c}\% \text { de Óleo } \\ \text { na Amostra }\end{array}\end{array}$

\begin{tabular}{|c|c|c|c|c|}
\hline \multirow{3}{*}{1} & \multirow{3}{*}{0 a $20 \mathrm{~cm}$} & 1 & 0 & 0,0 \\
\hline & & 4 & 0 & 0,0 \\
\hline & & 8 & 0 & 0,0 \\
\hline \multirow{3}{*}{2} & \multirow{3}{*}{20 a $40 \mathrm{~cm}$} & 1 & 1591 & 0,2 \\
\hline & & 4 & 1567 & 0,2 \\
\hline & & 5 & 20000 & 2,0 \\
\hline
\end{tabular}




\begin{tabular}{|c|c|c|c|c|}
\hline & & 7 & 7218 & 0,7 \\
\hline & & 10 & 25175 & 2,5 \\
\hline & & 12 & 20000 & 2,0 \\
\hline & & 13 & 3669 & 0,4 \\
\hline & & 15 & 19120 & 1,9 \\
\hline & & 18 & 0 & 0,0 \\
\hline & & 27 & 0 & 0,0 \\
\hline & & 36 & 0 & 0,0 \\
\hline & & 39 & 0 & 0,0 \\
\hline & & 51 & 0 & 0,0 \\
\hline \multirow{13}{*}{3} & \multirow{13}{*}{40 a $60 \mathrm{~cm}$} & 1 & 20000 & 2,0 \\
\hline & & 3 & 20000 & 2,0 \\
\hline & & 6 & 20000 & 2,0 \\
\hline & & 11 & 20000 & 2,0 \\
\hline & & 5 & 22747 & 2,3 \\
\hline & & 7 & 21387 & 2,1 \\
\hline & & 10 & 37237 & 3,7 \\
\hline & & 15 & 24861 & 2,5 \\
\hline & & 16 & 9057 & 0,9 \\
\hline & & 20 & 0 & 0,0 \\
\hline & & 25 & 0 & 0,0 \\
\hline & & 32 & 0 & 0,0 \\
\hline & & 36 & 0 & 0,0 \\
\hline \multirow{14}{*}{4} & \multirow{14}{*}{60 a $80 \mathrm{~cm}$} & 2 & 10963 & 1,1 \\
\hline & & 3 & 20000 & 2,0 \\
\hline & & 6 & 20000 & 2,0 \\
\hline & & 7 & 19758 & 2,0 \\
\hline & & 8 & 20000 & 2,0 \\
\hline & & 9 & 20000 & 2,0 \\
\hline & & 10 & 26463 & 2,6 \\
\hline & & 11 & 20000 & 2,0 \\
\hline & & 12 & 19586 & 2,0 \\
\hline & & 13 & 4575 & 0,5 \\
\hline & & 14 & 20000 & 2,0 \\
\hline & & 17 & 81 & 0,0 \\
\hline & & 28 & 92 & 0,0 \\
\hline & & 31 & 0 & 0,0 \\
\hline \multirow{11}{*}{5} & \multirow{11}{*}{80 a $100 \mathrm{~cm}$} & 2 & 12566 & 1,3 \\
\hline & & 3 & 24777 & 2,5 \\
\hline & & 4 & 20000 & 2,0 \\
\hline & & 5 & 30240 & 3,0 \\
\hline & & 6 & 27791 & 2,8 \\
\hline & & 7 & 20000 & 2,0 \\
\hline & & 10 & 20000 & 2,0 \\
\hline & & 11 & 15332 & 1,5 \\
\hline & & 13 & 20000 & 2,0 \\
\hline & & 15 & 2469 & 0,2 \\
\hline & & 21 & 0 & 0,0 \\
\hline
\end{tabular}




\begin{tabular}{|c|c|c|c|c|}
\hline & & 24 & 17 & 0,0 \\
\hline & & 29 & 0 & 0,0 \\
\hline & & 32 & 0 & 0,0 \\
\hline \multirow{5}{*}{6} & \multirow{5}{*}{100 a $120 \mathrm{~cm}$} & 2 & 0 & 0,0 \\
\hline & & 3 & 9775 & 1,0 \\
\hline & & 6 & 0 & 0,0 \\
\hline & & 7 & 0 & 0,0 \\
\hline & & 11 & 0 & 0,0 \\
\hline \multirow{4}{*}{7} & \multirow{4}{*}{$\begin{array}{l}120 \mathrm{~cm} \text { até o } \\
\text { fundo }\end{array}$} & 1 & 0 & 0,0 \\
\hline & & 2 & 0 & 0,0 \\
\hline & & 7 & 0 & 0,0 \\
\hline & & 11 & 0 & 0,0 \\
\hline
\end{tabular}

Tabela 4.6 - Resultado da análise das amostras do terceiro ensaio

\begin{tabular}{|c|c|c|c|c|}
\hline Camada & Profundidade & Amostra & $\begin{array}{l}\text { ppm de Óleo } \\
\text { na Amostra }\end{array}$ & $\begin{array}{c}\text { \% de Óleo } \\
\text { na Amostra }\end{array}$ \\
\hline \multirow{15}{*}{1} & \multirow{15}{*}{0 a $30 \mathrm{~cm}$} & 1 & 20000 & 2,0 \\
\hline & & 2 & 3997 & 0,4 \\
\hline & & 3 & 20000 & 2,0 \\
\hline & & 6 & 20000 & 2,0 \\
\hline & & 7 & 26925 & 2,7 \\
\hline & & 10 & 38640 & 3,9 \\
\hline & & 11 & 20000 & 2,0 \\
\hline & & 12 & 28875 & 2,9 \\
\hline & & 14 & 20000 & 2,0 \\
\hline & & 15 & 10847 & 1,1 \\
\hline & & 16 & 12693 & 1,3 \\
\hline & & 22 & 0 & 0,0 \\
\hline & & 23 & 0 & 0,0 \\
\hline & & 31 & 0 & 0,0 \\
\hline & & 39 & 0 & 0,0 \\
\hline \multirow{15}{*}{2} & \multirow{15}{*}{30 a $55 \mathrm{~cm}$} & 1 & 15534 & 1,6 \\
\hline & & 2 & 20000 & 2,0 \\
\hline & & 4 & 20000 & 2,0 \\
\hline & & 6 & 5110 & 0,5 \\
\hline & & 7 & 20000 & 2,0 \\
\hline & & 8 & 26851 & 2,7 \\
\hline & & 10 & 20000 & 2,0 \\
\hline & & 11 & 21134 & 2,1 \\
\hline & & 13 & 1141 & 0,1 \\
\hline & & 14 & 16609 & 1,7 \\
\hline & & 15 & 20000 & 2,0 \\
\hline & & 17 & 0 & 0,0 \\
\hline & & 28 & 0 & 0,0 \\
\hline & & 34 & 0 & 0,0 \\
\hline & & 39 & 0 & 0,0 \\
\hline
\end{tabular}




\begin{tabular}{|c|c|c|c|c|}
\hline \multirow{14}{*}{3} & \multirow{14}{*}{55 a $80 \mathrm{~cm}$} & 2 & 20000 & 2,0 \\
\hline & & 3 & 3870 & 0,4 \\
\hline & & 5 & 1712 & 0,2 \\
\hline & & 6 & 38743 & 3,9 \\
\hline & & 7 & 20000 & 2,0 \\
\hline & & 9 & 1606 & 0,2 \\
\hline & & 10 & 20000 & 2,0 \\
\hline & & 11 & 3237 & 0,3 \\
\hline & & 12 & 20000 & 2,0 \\
\hline & & 15 & 11865 & 1,2 \\
\hline & & 16 & 87 & 0,0 \\
\hline & & 20 & 0 & 0,0 \\
\hline & & 25 & 0 & 0,0 \\
\hline & & 40 & 0 & 0,0 \\
\hline \multirow{17}{*}{4} & \multirow{17}{*}{80 a $105 \mathrm{~cm}$} & 1 & 10739 & 1,1 \\
\hline & & 2 & 17226 & 1,7 \\
\hline & & 3 & 20000 & 2,0 \\
\hline & & 6 & 20000 & 2,0 \\
\hline & & 7 & 62177 & 6,2 \\
\hline & & 8 & 20000 & 2,0 \\
\hline & & 9 & 1683 & 0,2 \\
\hline & & 11 & 20000 & 2,0 \\
\hline & & 12 & 23249 & 2,3 \\
\hline & & 14 & 671 & 0,1 \\
\hline & & 15 & 3423 & 0,3 \\
\hline & & 16 & 0 & 0,0 \\
\hline & & 17 & 0 & 0,0 \\
\hline & & 28 & 0 & 0,0 \\
\hline & & 31 & 0 & 0,0 \\
\hline & & 34 & 0 & 0,0 \\
\hline & & 39 & 0 & 0,0 \\
\hline \multirow{5}{*}{5} & \multirow{5}{*}{$105 \mathrm{~cm}$ até o fundo } & 2 & 0 & 0,0 \\
\hline & & 7 & 0 & 0,0 \\
\hline & & 9 & 0 & 0,0 \\
\hline & & 10 & 0 & 0,0 \\
\hline & & 12 & 0 & 0,0 \\
\hline
\end{tabular}

A partir dos dados acima, foram elaborados gráficos com a média da região contaminada pelo óleo, e a concentração máxima de cada camada (Fig. 4.12, 4.13 e 4.14).

Em todos os casos, a concentração média ficou em torno de $2 \%$ de óleo. Este dado foi utilizado no HSSM para a simulação da pluma de contaminação. 


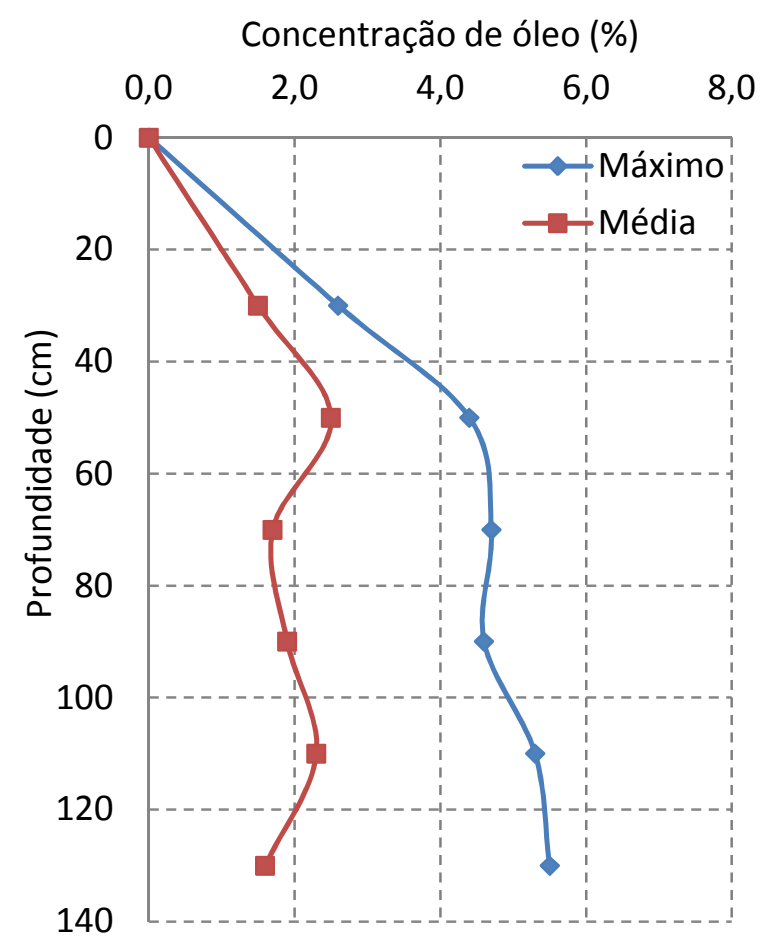

Figura 4.12 - Concentrações máxima e média de óleo em cada camada do primeiro ensaio

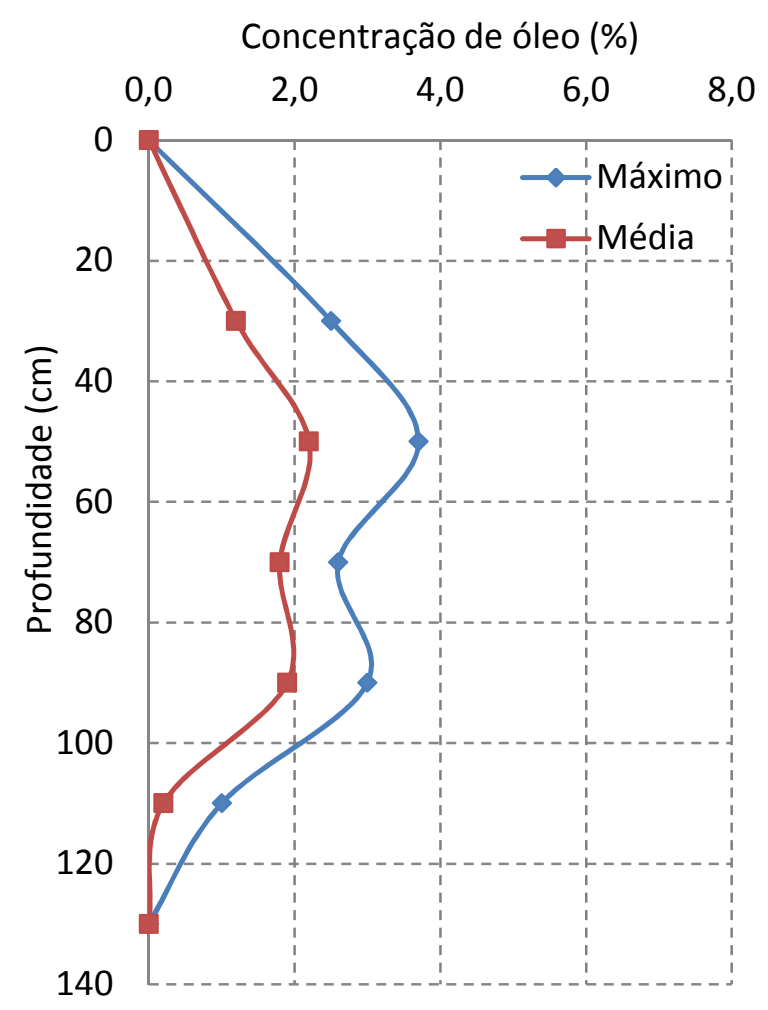

Figura 4.13 - Concentrações máxima e média de óleo em cada camada do segundo ensaio 
Na Figura 4.13 nota-se a diminuição da concentração de óleo na faixa de $100 \mathrm{~cm}$ de profundidade. É exatamente nesta faixa onde está o nível d'água, indicando que não passou óleo além do mesmo. A existência de um ponto com concentração de óleo na camada que estava submersa pode ser explicada por problemas encontrados no momento da extração das amostras devido a presença de água, podendo ter causado a contaminação do ponto 3 da camada 6 .

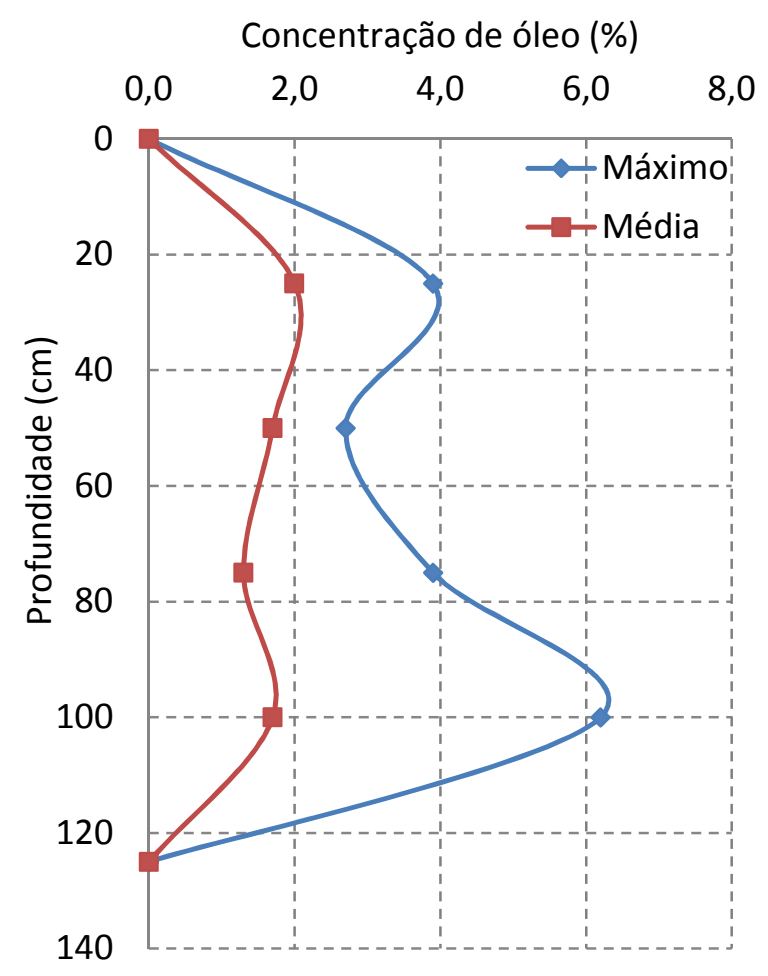

Figura 4.14 - Concentrações máxima e média de óleo em cada camada do terceiro ensaio

Esperava-se que o perfil de concentrações do terceiro ensaio fosse semelhante ao do primeiro, o que foi confirmado, exceto o último ponto. O que pode ter causado a inexistência de óleo na última camada é a presença de água no solo, causando o retardamento do avanço.

A partir dos dados do primeiro ensaio, e fotos das manchas da pluma retiradas no local, no momento da coleta, foram elaborados gráficos com as concentrações de cada camada para facilitar a visualização da pluma (Figuras 4.15, 4.16, 4.17, 4.18, 4.19 e 4.20). Observa-se que existem, em cada camada, pontos onde a concentração é maior, indicando que sempre existe um caminho preferencial seguido pelo NAPL. 

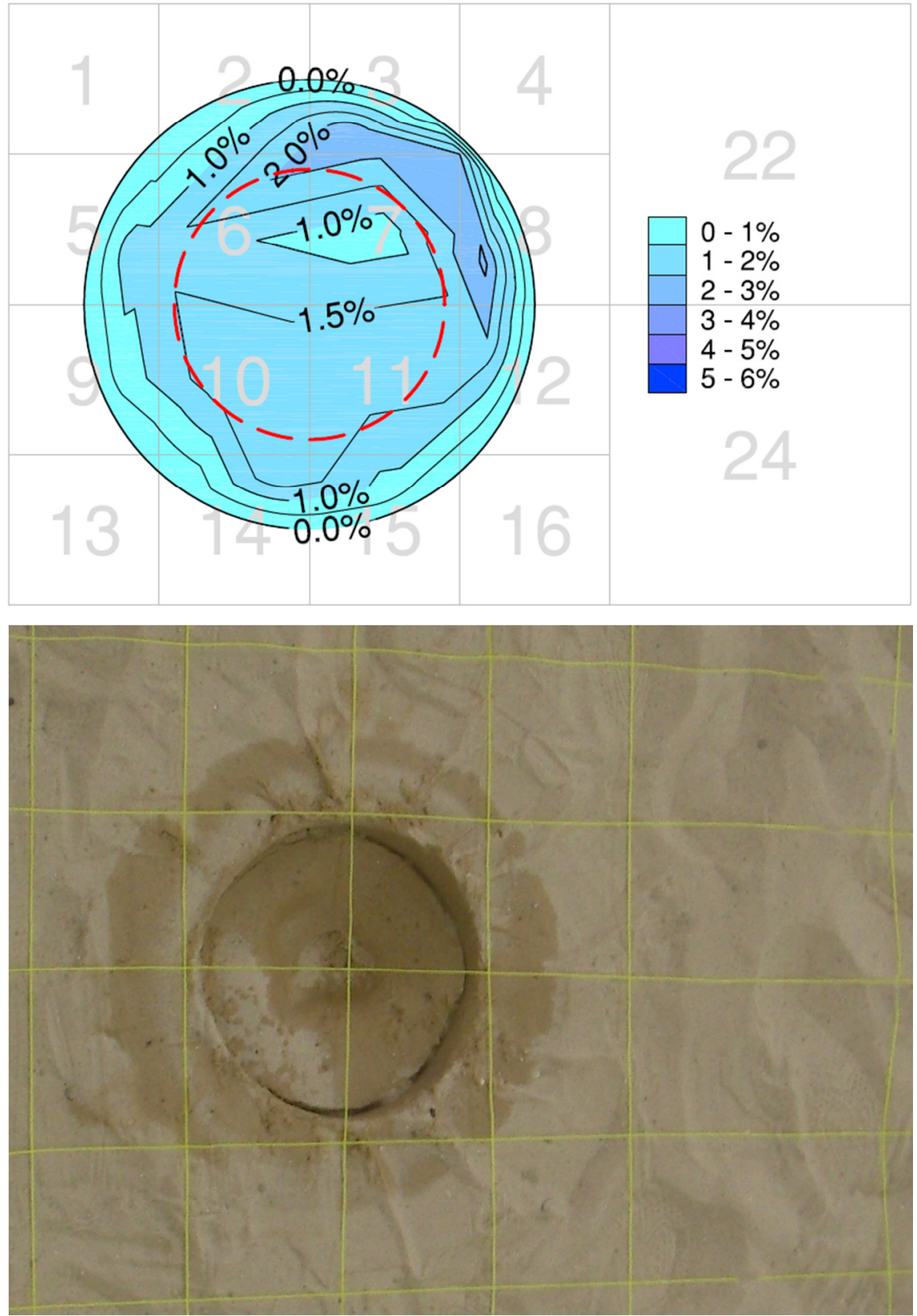

Figura 4.15 - Concentração de óleo e a foto da camada 2 

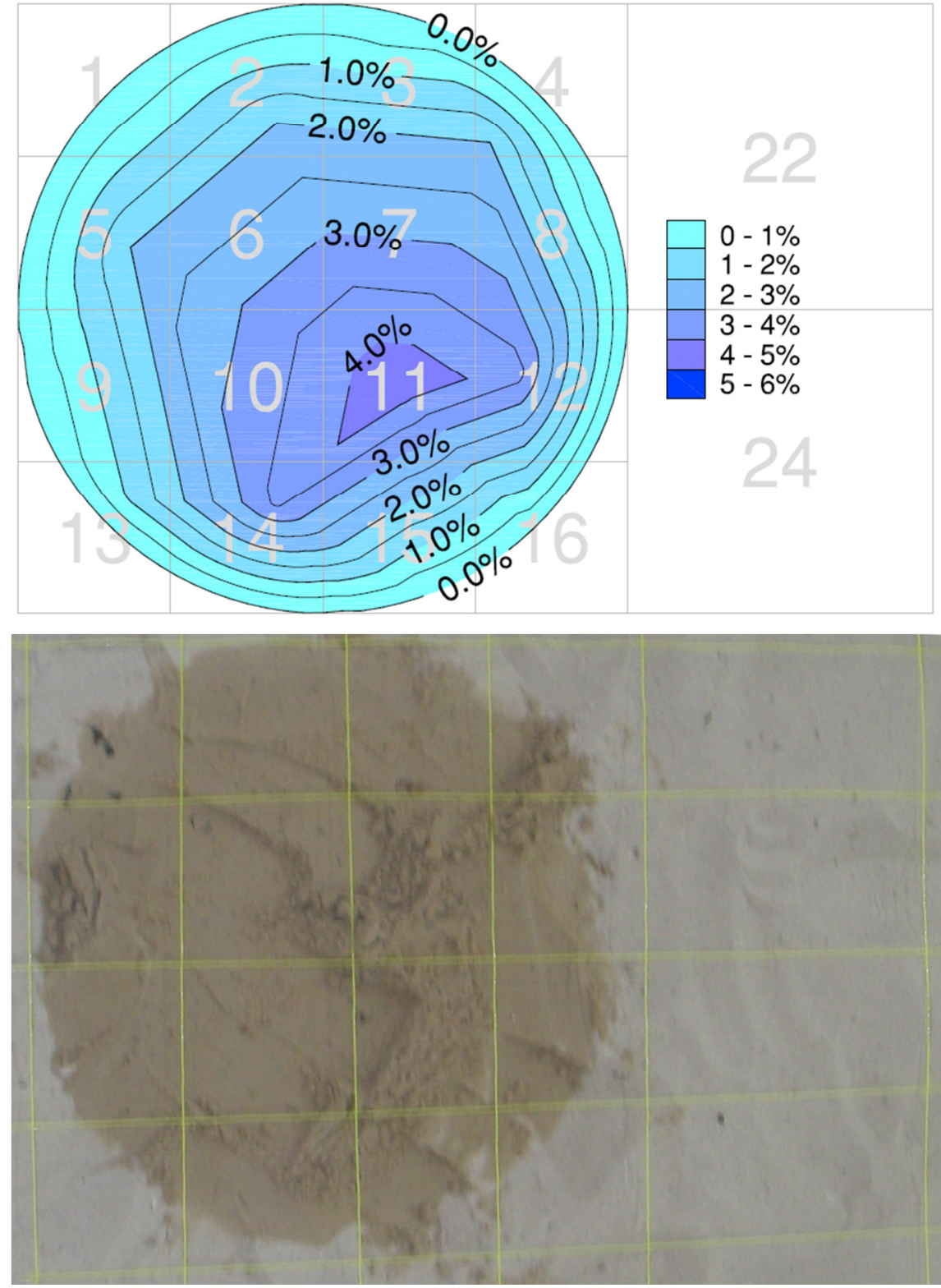

Figura 4.16 - Concentração de óleo e a foto da camada 3 

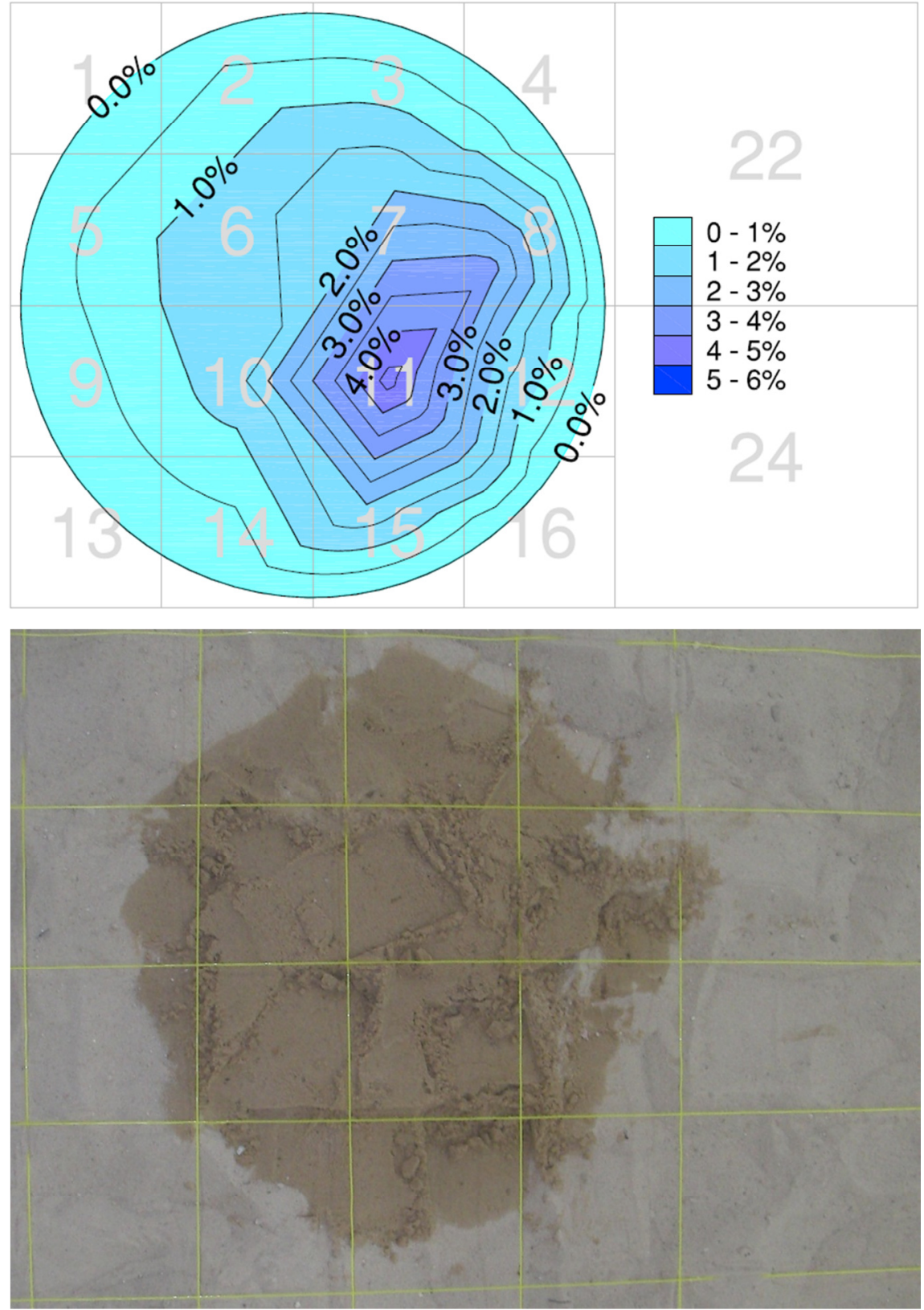

Figura 4.17 - Concentração de óleo e a foto da camada 4 

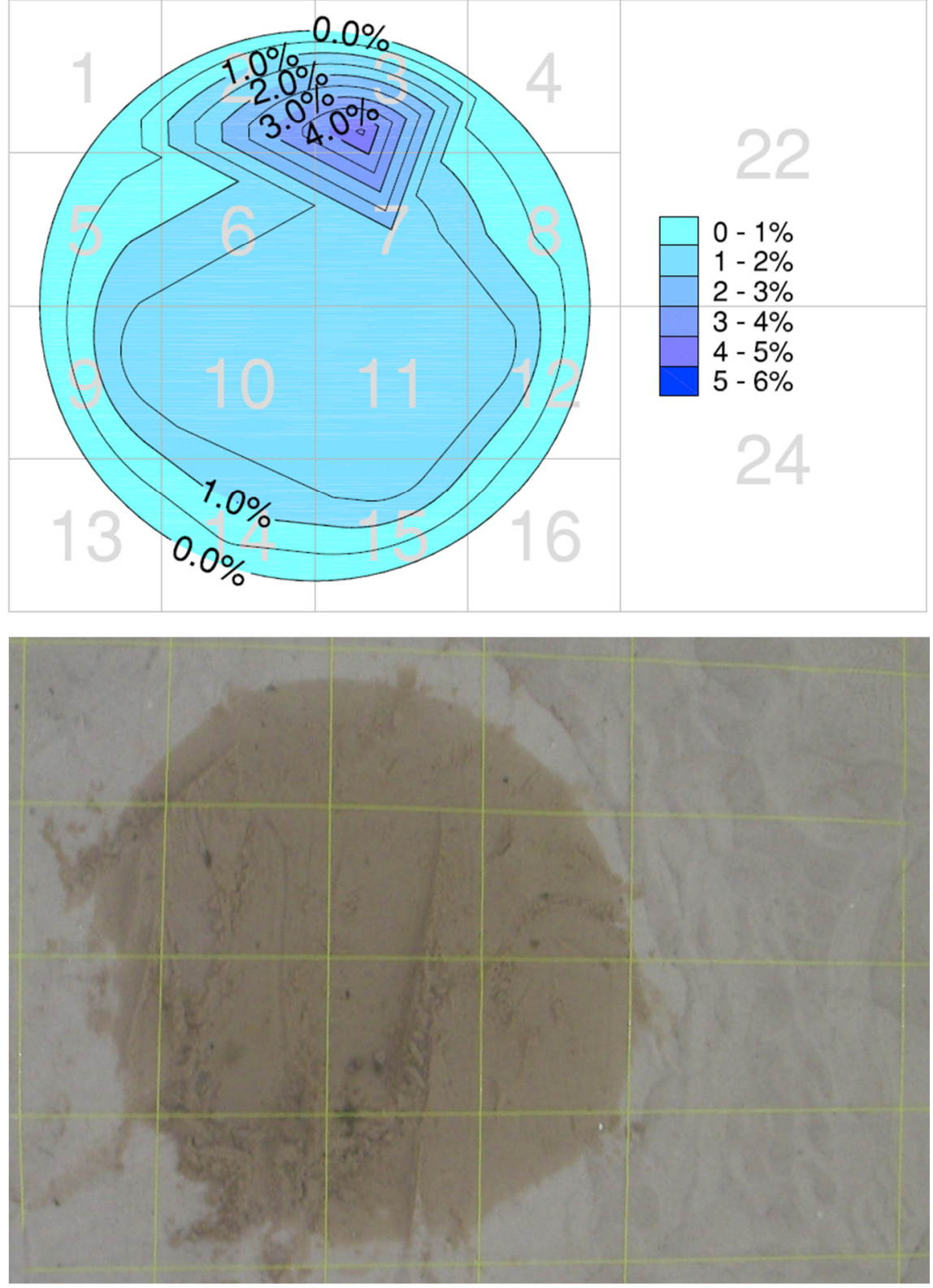

Figura 4.18 - Concentração de óleo e a foto da camada 5 

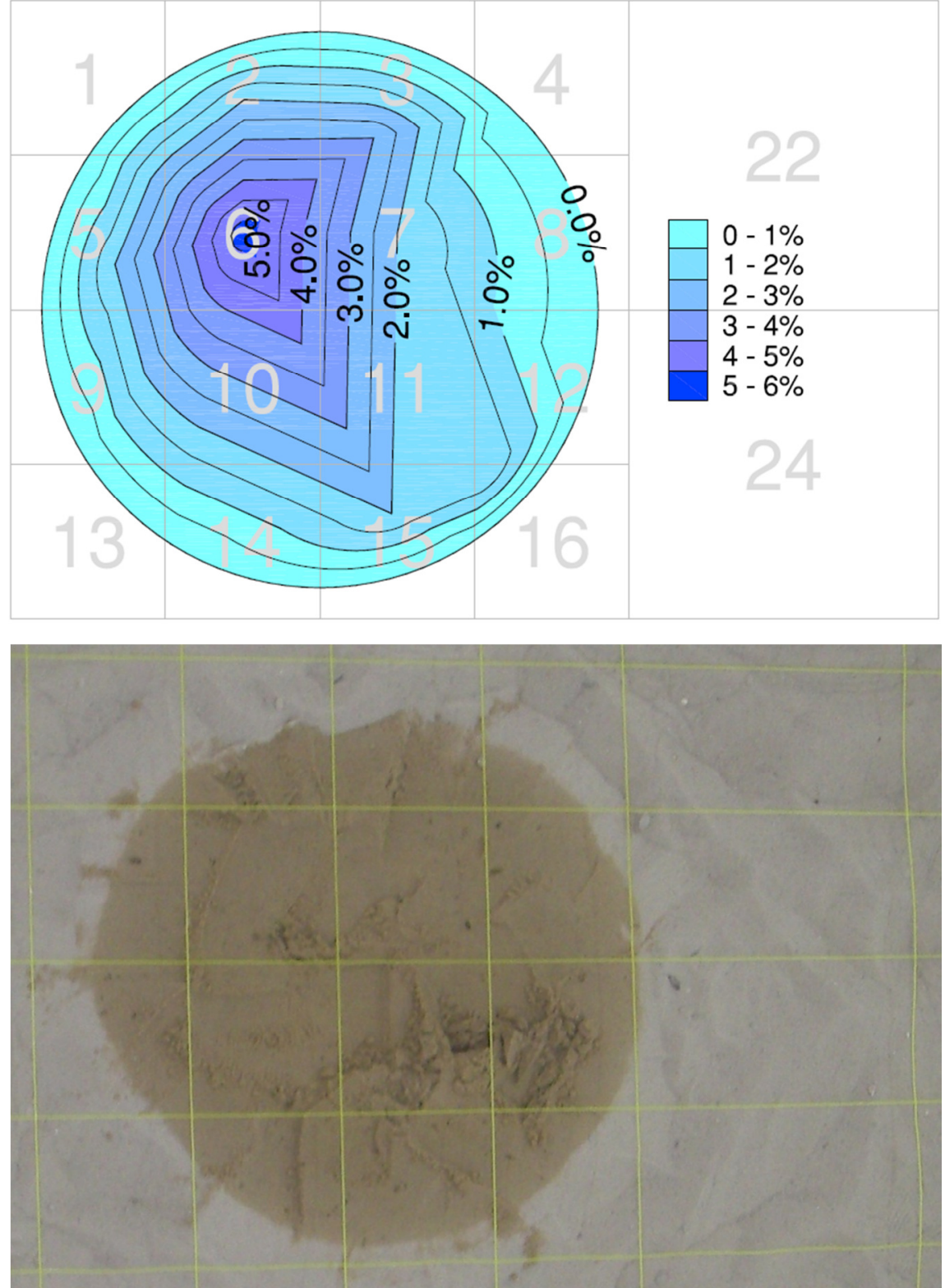

Figura 4.19 - Concentração de óleo e a foto da camada 6 

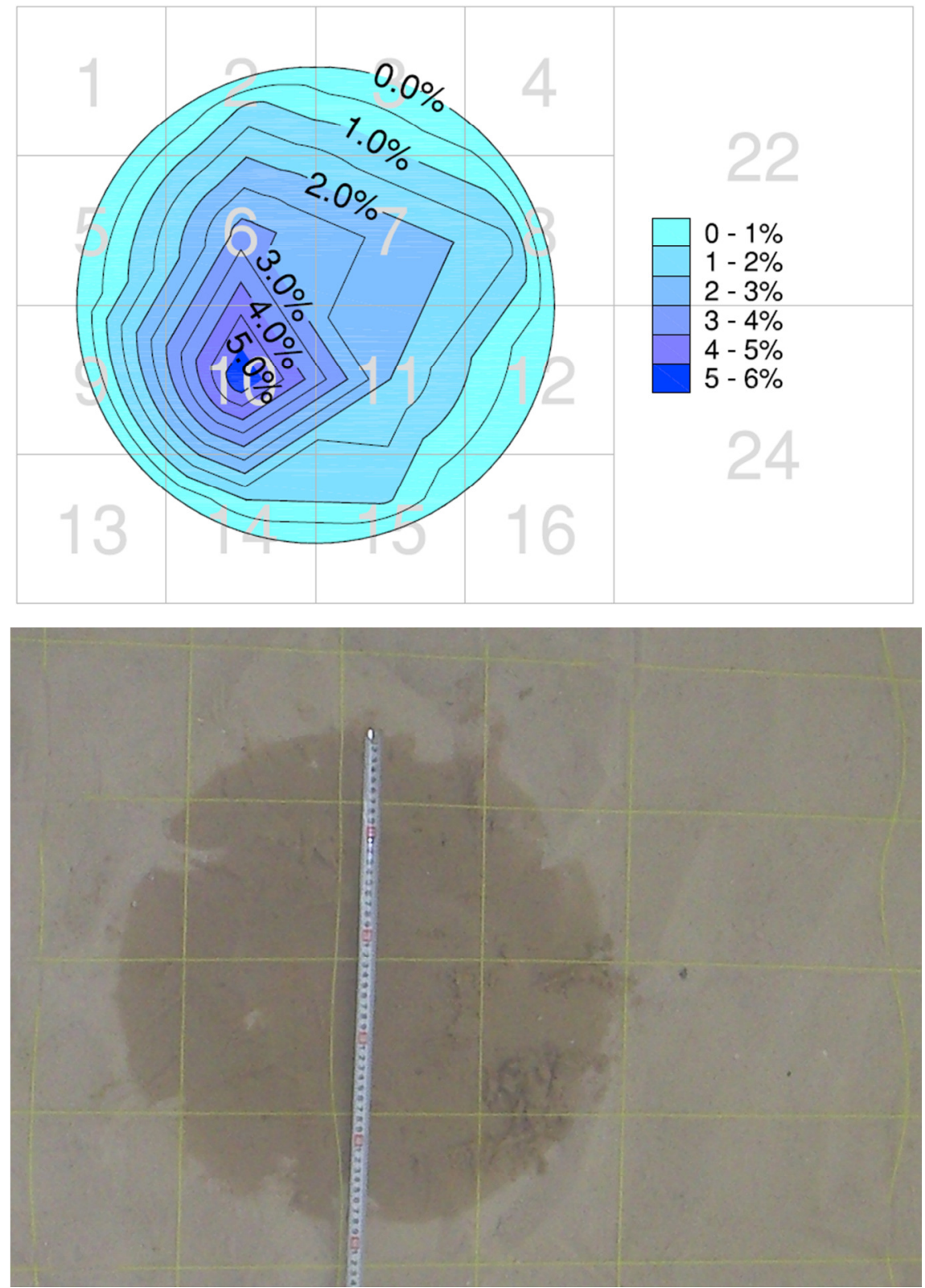

Figura 4.20 - Concentração de óleo e a foto da camada 7

Comparando as Figuras 4.15 a 4.20 com a Figura 4.12, nota-se que a concentração de óleo aumenta com a profundidade, enquanto o diâmetro da pluma diminui. Isso indica que a pluma ainda não ficou estável, com a tendência de se expandir mais.

Não foi possível elaborar figuras semelhantes para o segundo e terceiro ensaios, pois não era possível distinguir o limite da pluma de cada camada visualmente. 
4.4 Simulação com o HSSM

Dados importantes foram colhidos dos ensaios de laboratório e do modelo físico. A partir dos ensaios de laboratório foram utilizados os parâmetros de saturação residual de água (Swr), $\alpha$ e $\mathrm{n}$ de van Genuchten, a condutividade hidráulica saturada e as propriedades físicas do solo. Do modelo físico, foi obtida a saturação residual de NAPL na zona vadosa, um parâmetro que influencia muito na simulação numérica, mas de difícil determinação.

As três simulações foram executadas com os mesmos parâmetros nas propriedades da fase de hidrocarbonetos e nos parâmetros de simulação. As propriedades hidrológicas foram diferentes, com os parâmetros de acordo com a condição de cada ensaio, que estão descritos nos itens a seguir.

Para o segundo ensaio foi considerado a saturação de $30 \%$, que é a média da saturação da zona vadosa (determinada a partir das amostras coletadas no local). 0 terceiro ensaio também tem a saturação considerada como a média da saturação das camadas coletadas do local, que é de $20 \%$.

\subsubsection{Primeiro Ensaio}

No primeiro ensaio, foi considerado o valor mínimo de saturação residual de água, pois o solo foi seco à umidade higroscópica. Além disso, foi considerado que o nível d'água estivesse a 50 metros de profundidade para não influenciar a simulação (Figura 4.21). 


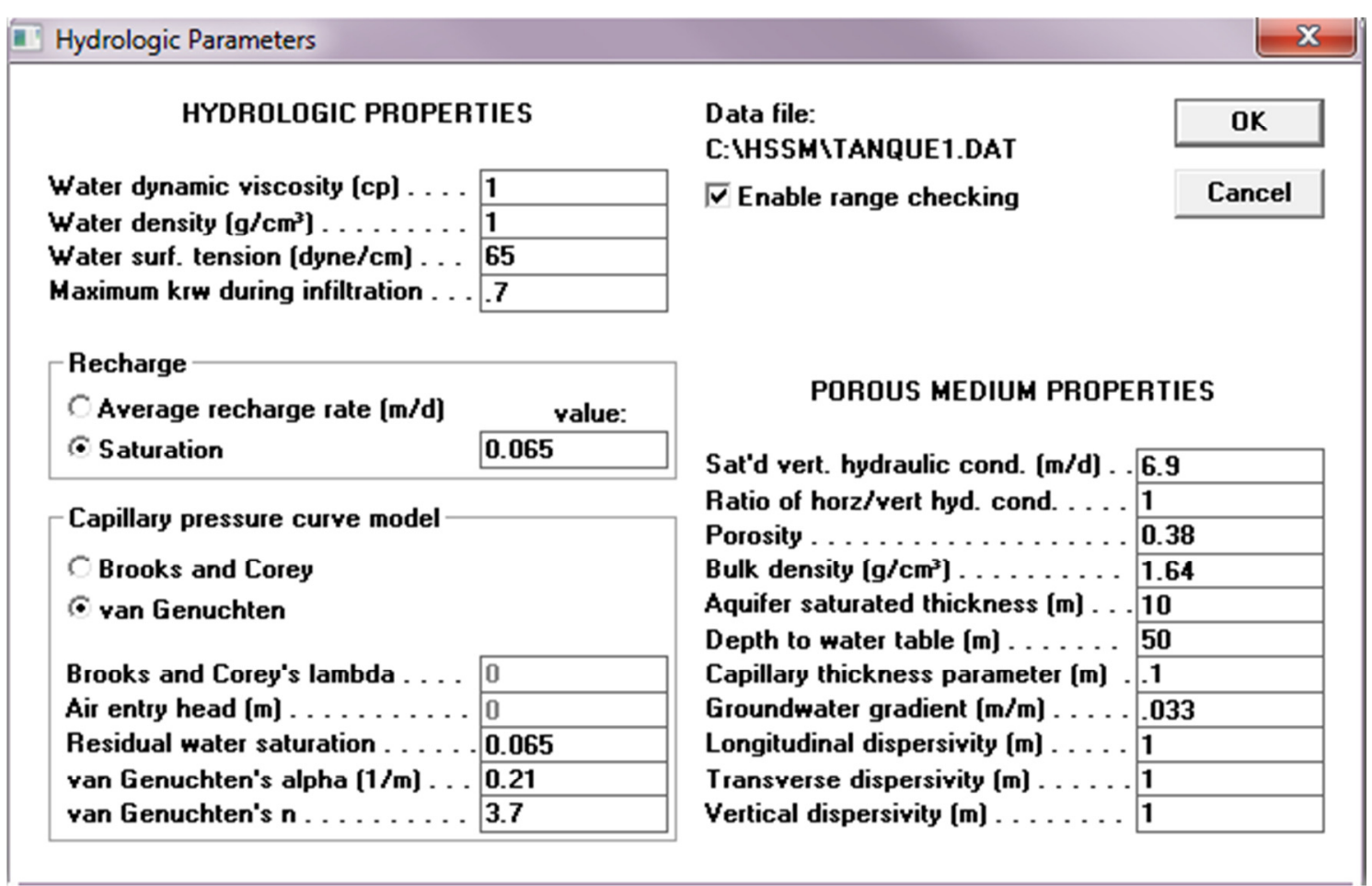

Figura 4.21 - Parâmetros Hidráulicos da simulação do primeiro ensaio

O resultado da simulação está na Figura 4.22.

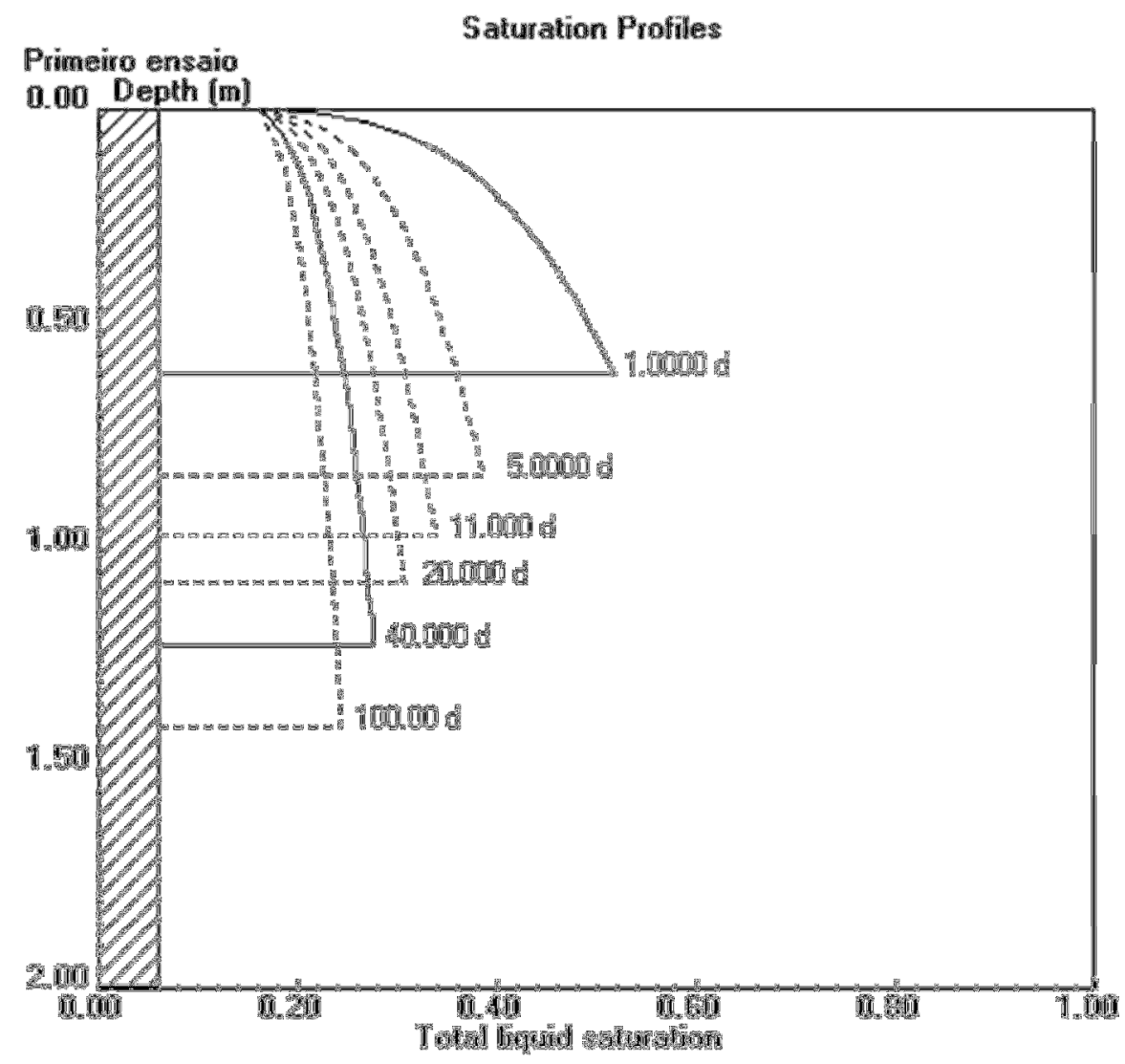

Figura 4.22 - Resultado da simulação do primeiro ensaio 
4.4.2 Segundo Ensaio

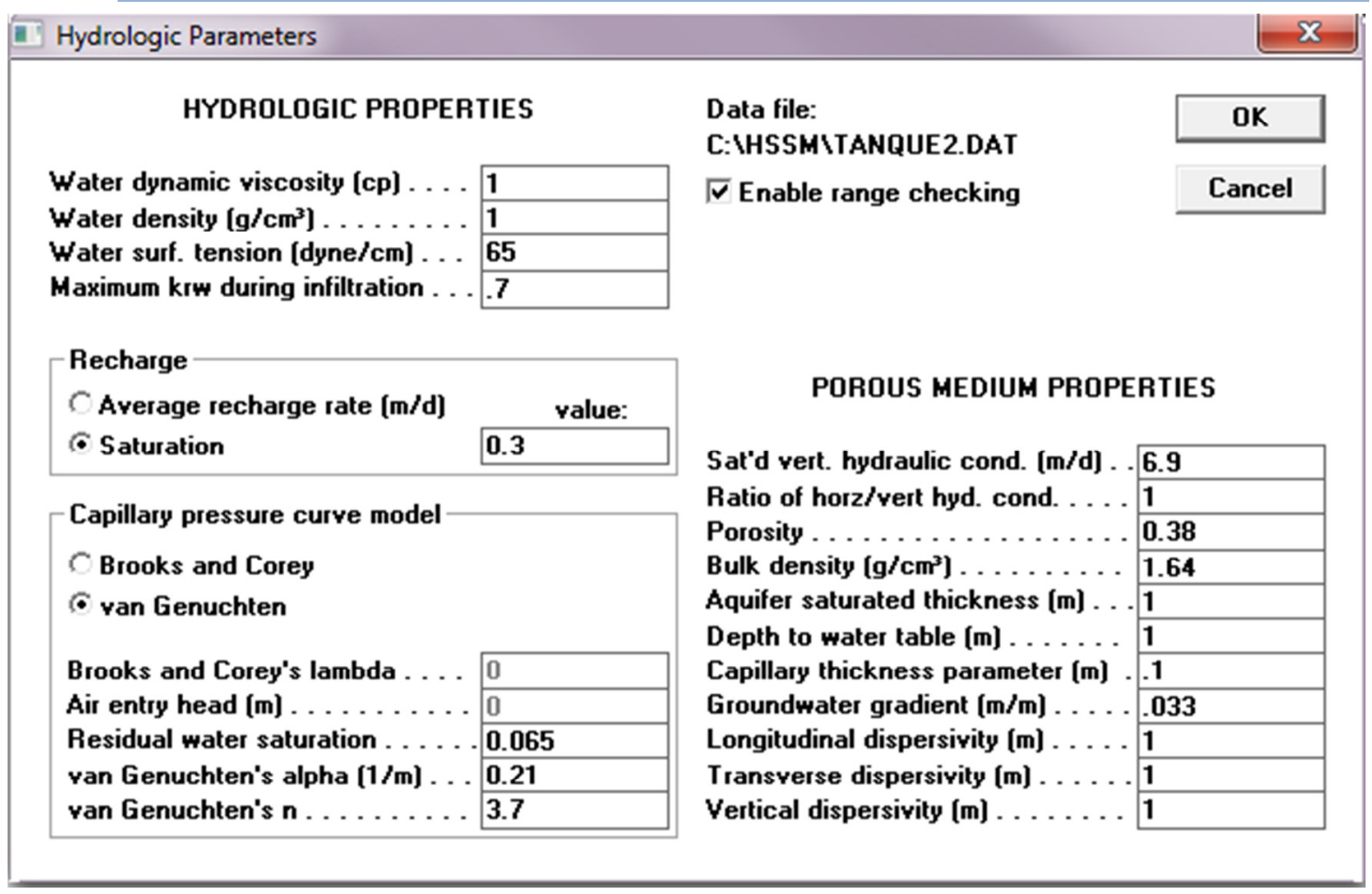

Figura 4.23 - Parâmetros Hidráulicos da simulação do segundo ensaio

A Figura 4.23 apresenta os parâmetros utilizados para a simulação do segundo ensaio. A saturação considerada foi obtida de amostras colhidas com o objetivo de verificar a umidade do solo. A profundidade do aquífero foi o mesmo que no ensaio com o modelo físico, com 1 metro de profundidade.

A simulação apresentou o resultado que está apresentado na Figura 4.24.

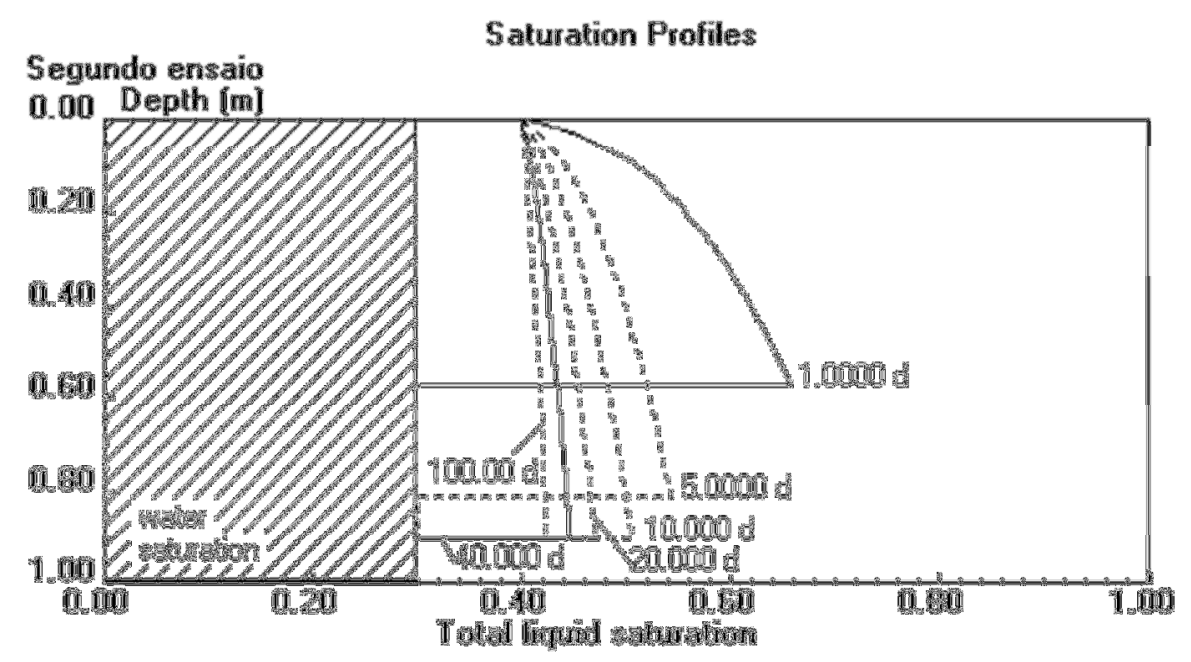

Figura 4.24 - Resultado da simulação do segundo ensaio 


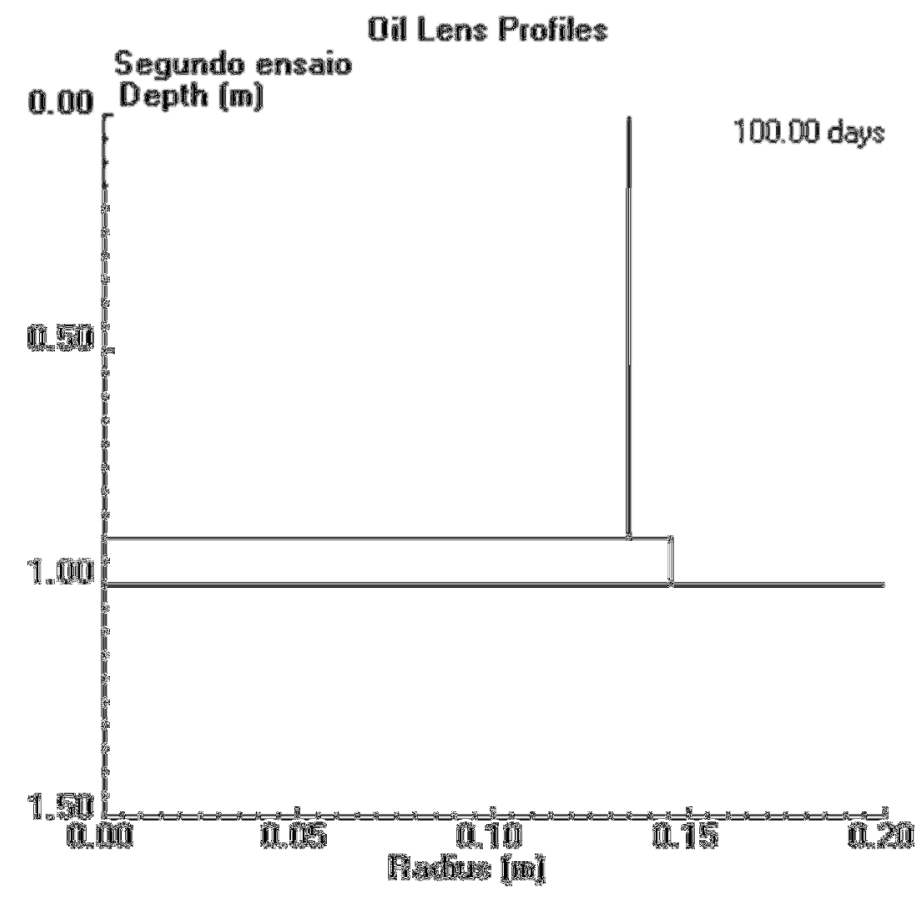

Figura 4.25 - Lente de NAPL formada sobre o aquífero

A Figura 4.25 apresenta o resultado de uma lente de cerca de $20 \mathrm{~cm}$ seria formada após 100 dias do início do ensaio. Aqui pode ser notada a simplificação do programa, onde o raio da pluma é constante na zona vadosa.

\subsubsection{Terceiro Ensaio}

A última simulação realizada foi do terceiro ensaio, onde o solo estava apenas úmido, sem nível de água. A Figura 4.26 apresenta os parâmetros utilizados para essa simulação, e a Figura 4.27 que está em seguida mostra o resultado da simulação.

Comparando os três resultados, observa-se que o tempo de expansão da pluma não é influenciado com a variação da saturação, pois o formato do perfil de saturação por NAPL nos três casos é muito semelhante. 


\begin{tabular}{|c|c|}
\hline Hydrologic Parameters & \\
\hline \multicolumn{2}{|c|}{ HYDROLOGIC PROPERTIES } \\
\hline Water dynamic viscosity [cp] . . . & 1 \\
\hline Water density $\left[\mathrm{g} / \mathrm{cm}^{3}\right] \ldots \ldots$ & 1 \\
\hline Water surf. tension [dyne/cm] . . . & 65 \\
\hline Maximum krw during infiltration ... & .7 \\
\hline \multicolumn{2}{|l|}{$\Gamma$ Recharge -} \\
\hline Average recharge rate $[\mathrm{m} / \mathrm{d}]$ & value: \\
\hline Saturation & 0.2 \\
\hline \multicolumn{2}{|l|}{ Capillary pressure curve model -} \\
\hline \multicolumn{2}{|l|}{ Brooks and Corey } \\
\hline \multicolumn{2}{|l|}{ C van Genuchten } \\
\hline Brooks and Corey's lambda . . . . . & 0 \\
\hline Air entry head $(\mathrm{m}) \ldots \ldots \ldots \ldots$ & $\mathbf{0}$ \\
\hline Residual water saturation . . . . . & 0.065 \\
\hline van Genuchten's alpha $[1 / \mathrm{m}] .$. & 0.21 \\
\hline van Genuchten's n . . . . . . . & 3.7 \\
\hline
\end{tabular}

\section{Data file: \\ C: VHSSMITANQUE3.DAT}

$\varpi$ Enable range checking

Cancel

\section{POROUS MEDIUM PROPERTIES}

Sat'd vert. hydraulic cond. $[\mathrm{m} / \mathrm{d}]$. . 6.9

Ratio of horz/vert hyd. cond. . . . 1

Porosity . . . . . . . . . . . 0.38

Bulk density $\left[\mathrm{g} / \mathrm{cm}^{3}\right]$. . . . . . . 1.64

Aquifer saturated thickness (m) . . 1

Depth to water table $(\mathrm{m})$. . . . . . 5

Capillary thickness parameter $(\mathrm{m}) .01$

Groundwater gradient $(\mathrm{m} / \mathrm{m}) \ldots . .033$

Longitudinal dispersivity (m) . . . . 10

Transverse dispersivity (m) . . . . . 1

Vertical dispersivity $(\mathrm{m}) \ldots . . . .1$

Figura 4.26 - Parâmetros Hidráulicos da simulação do terceiro ensaio

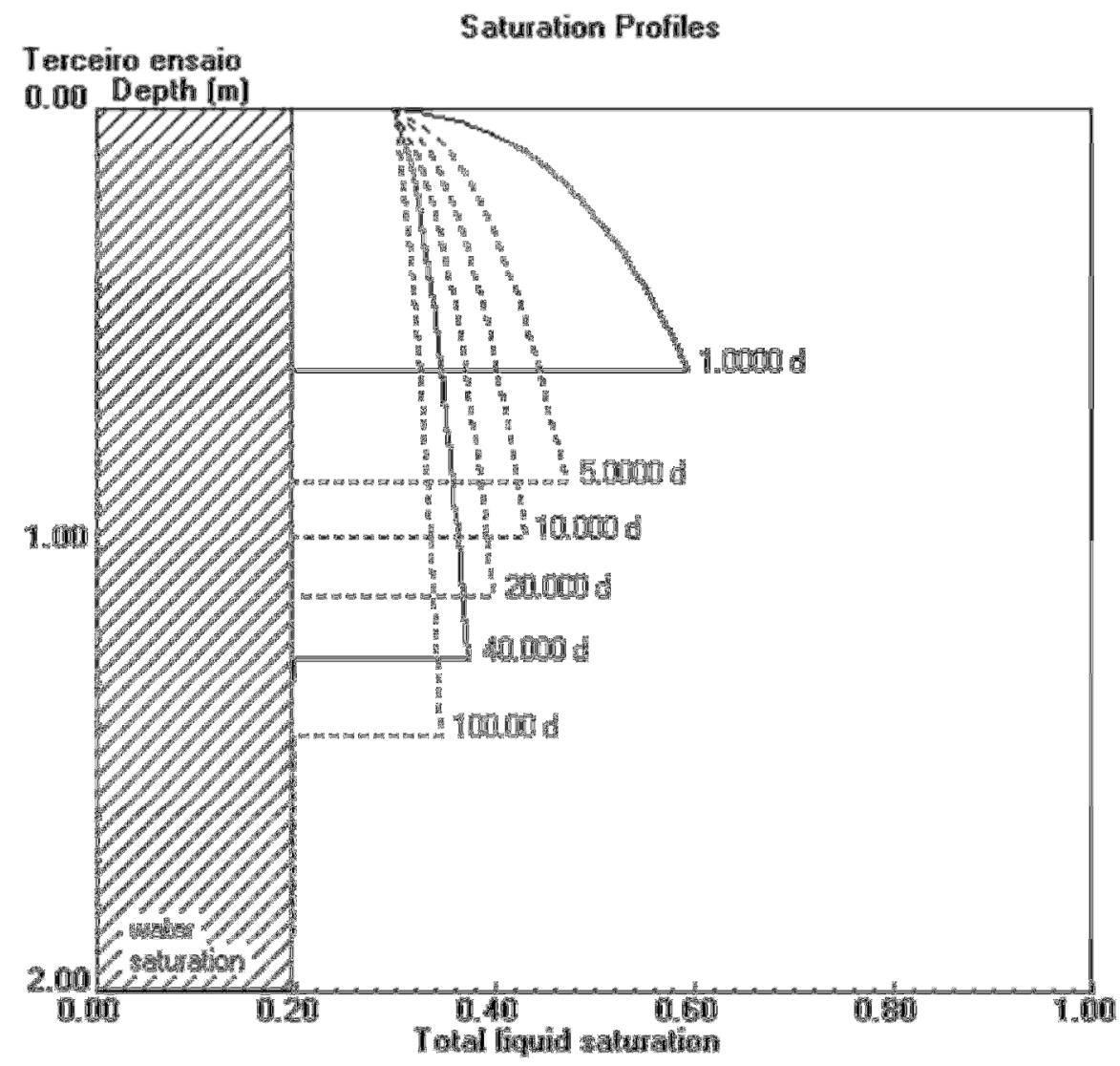

Figura 4.27 - Resultado da simulação do terceiro ensaio 
4.5 Comparação entre o modelo físico e o numérico

No primeiro ensaio, observa-se que o tempo de expansão da pluma de contaminação por NAPL é um pouco diferente. No caso do modelo físico, o tempo para que a pluma atinja a profundidade de $130 \mathrm{~cm}$ foi de 11 dias, quando foram coletadas as amostras. Na simulação numérica, observa-se que em 11 dias a pluma não atinge $100 \mathrm{~cm}$ de profundidade, atingindo a mesma profundidade do modelo físico apenas em 40 dias. Levando em conta que o modelo tem a simplificação de que o raio da pluma na zona vadosa não muda, nota-se que o modelo subestima a velocidade de expansão da pluma de contaminação para este caso, onde a umidade é atípica, pois dificilmente seria encontrado um local com a umidade perto da higroscópica.

Os resultados obtidos com as simulações físicas e numéricas do segundo ensaio podem ser considerados coerentes, pois as concentrações apresentadas na simulação estão semelhantes ao dos encontrados pelo analisador de óleo. E nos dois casos, foi observado que o NAPL ficou retido sobre o aquífero, não o ultrapassando.

Comparando o perfil gerado pelo modelo numérico e o perfil montado a partir dos dados do terceiro ensaio, observa-se grande semelhança. Na simulação numérica a pluma avançou até a profundidade de $120 \mathrm{~cm}$, a mesma faixa onde no experimento físico acaba a pluma de contaminação.

Com as observações acima, o programa HSSM pode ser considerado como uma boa ferramenta para estimar o avanço da pluma na zona vadosa em condições normais. Em casos extremos, como no primeiro ensaio que quase não há água no ambiente, a simulação numérica apresenta resultados muito diferentes. 


\section{Conclusões}

Dos ensaios realizados para a obtenção da curva de retenção do solo, foram observadas pequenas diferenças entre as curvas de 2, 5, 10 e 15\% de óleo. Por isso, a principal influência do óleo no solo será sobre as características do solo, como a porosidade.

A adição de óleo ao meio poroso proporciona o aumento da umidade residual, o que era esperado, pois o NAPL utilizado não era volátil à temperatura ambiente, não apresentando perdas significativas durante o ensaio.

A obtenção da curva de retenção não seria favorável para a utilização na prática comercial, pois o tempo gasto neste ensaio é no mínimo de seis meses, devido ao longo tempo para a estabilização da umidade.

No ensaio com o modelo físico com o solo seco e somente óleo, foi possível verificar o formato da pluma de contaminação por óleo já estável. Onde o diâmetro do cilindro formado pelo óleo tinha quase o dobro do diâmetro da fonte.

O fato de existir o nível d'água no segundo ensaio com o modelo físico confirmou o esperado, onde a pluma de contaminação permaneceu sobre o aquífero, não atravessando o mesmo.

No terceiro ensaio, foi observado que, com a presença da água de modo parcial no solo, retardou o avanço da pluma de NAPL devido à diminuição dos vazios.

Como observado por Nacimento et al. (2008), a utilização do InfraCal para a análise de amostras coletadas deve se restringir para a análise da existência de hidrocarbonetos no solo, e não tentar quantificar precisamente o poluente.

O programa HSSM pode ser considerado como uma boa ferramenta para estimar o avanço da pluma na zona vadosa em condições normais. Em casos extremos, como no primeiro ensaio que quase não há água no ambiente, a simulação numérica apresenta resultados muito diferentes. 


\section{Bibliografia}

CASTRO FILHO, G. B. Estudo do Fluxo e Transporte de Gasolina Pura e Misturada com Etanol em Meios Porosos Não Saturados. 2007. 155 p. Dissertação (Mestrado). Departamento de Engenharia Civil, Pontifícia Universidade Católica do Rio de Janeiro, Rio de Janeiro, 2007.

ESSINGTON, M. E. Soil and Water Chemistry: an integrative approach / by Michael E. Essington. 2004. 534 p. Boca Raton, CRC Press.

ESTADOS UNIDOS. Environmental Protection Agency. DNAPL Site Characterization. 1994. $12 \quad$ p. $\quad$ Disponível em: <http://www.epa.gov/superfund/health/conmedia/gwdocs/pdfs/dnapl.pdf>. Acesso de 30 de ago. 2007.

FETTER, C. W. Contaminant Hydrology. 1992. 458 p. New York, USA. Macmilan Publishing Company.

HILLEL, D. Environmental Soil Physics. 1998. 771 p. California, USA. Academic Press.

KECHAVARZI, C., SOGA, K., ILLANGASEKARE, T. H. Two-Dimensional Laboratory Simulation of LNAPL Infiltration and Redistribuition in the Vadose Zone. 2005. Journal of Contaminant Hydrology, V. 76, p. 211-233.

LENHARD, R. J., et al. Measurement of One-Dimensional Transient Three-Phase Flow for Monotonic Liquid Drainage. 1988. Water Resources Research, V. 24, No. 6, p. 853863.

LENHARD, R. J. Measurement and Modeling of Three-Phase Saturation-Pressure Hysteresis. 1992. Journal of Contaminant Hydrology, V. 9, p. 234-269.

LENHARD, R. J., JOHNSON, T. G., PARKER, J. C. Experimental Observations of Nonaqueous-Phase Liquid Subsurface Movement. 1993. Journal of Contaminant Hydrology, V. 12, p. 79-101.

MARINHO, F. A. M. Medição de Sucção em Solos. 1997. In: $3^{\circ}$ Simpósio Brasileiro de Solos Não Saturados - ÑSAT97, Rio de Janeiro, Anais.. p. 373-397. 
MITCHELL, J. K. Fundamentals of Soil Behavior. 1993. 437 p. New York, John Wiley \& Sons, Inc.

NASCIMENTO, A. R. Avaliação do Desempenho do Método de Determinação de TPH (Total Petroleum Hydrocarbon) em Areia por Detecção no Infravermelho. 2003. 100 p. Dissertação (Mestrado). Departamento de Metrologia para a Qualidade Industrial, Pontifícia Universidade do Rio de Janeiro, Rio de Janeiro, 2003.

NASCIMENTO, A. R. et al. Avaliação do Desempenho Analítico do Método de Determinação de TPH (Total Petroleum Hydrocarbon) por Detecção no Infravermelho. 2008. Eclética Química, v. 33, n. 1, p. $35-42$.

NEWELL, C. J. et. al. Ground Water Issue: Light Nonaqueous Phase Liquids. United States Environmental Protection Agency. 1995. 28 p. Disponível em: <http://www.epa.gov/tio/tsp/download/Inapl.pdf>. Acesso em 30 ago. 2007.

TELHADO, M. C. S. C. L. Avaliação as Biodisponibilidade de Contaminante Orgânico em Solo. 2009. 115 p. Dissertação (Mestrado). Escola de Química, Universidade Federal do Rio de Janeiro, Rio de Janeiro, 2009.

TROVÃO, R. S. Análise Ambiental de Solos e Águas Subterrâneas Contaminadas com Gasolina: estudo de caso no município de Guarulhos - SP. 2006. 157 p. Dissertação (Mestrado) - Escola Politécnica, Universidade de São Paulo, São Paulo, 2006.

VAN GENUCHTEN, M.T. (1980) A Closed From Equation for Predicting the Hydraulic Conductivity of Unsaturated Soils. Proc. Sci. Soc. Am. Vol 44 (5), 892-898.

VAN GELL, P. J., SYKES, J. F. Laboratory and Model Simulations of a LNAPL Spill in a Variably-Saturated Sand, 1. Laboratory Experiment and Image Analysis Techniques. 1994a. Journal of Contaminant Hydrology, V. 17, p. 1-25.

VAN GELL, P. J., SYKES, J. F. Laboratory and Model Simulations of a LNAPL Spill in a Variably-Saturated Sand, 2. Comparison of Laboratory and Model Results. 1994b. Journal of Contaminant Hydrology, V. 17, p. 27-53.

VIVIAN, J. B. Utilização do Método de Papel Filtro para a Determinação das Curvas Características de um Solo Coluvionar Não Saturado Contaminado com Óleo Diesel. 2008. 100 p. Dissertação (Mestrado). Escola de Engenharia, Universidade Federal do Rio Grande do Sul, Porto Alegre, 2008. 
The Hydrocarbon Spill Screening Model (HSSM) Volume 1: User's Guide. US-EPA e Universidade de Texas.

The Hydrocarbon Spill Screening Model (HSSM) Volume 2: Theoretical Background and Source Codes. US-EPA e Universidade de Texas. 


\section{Anexo I-Construção do Tanque Experimental}

O tanque experimental foi construído dentro de uma sala isolada, com ponto de água e energia elétrica. As dimensões do tanque foram limitadas pelas dimensões da sala.

O tanque experimental possui as medidas aproximadas de 2 metros de largura, 3 metros de comprimento e 1,4 metros de profundidade. A Figura I.1 apresenta o projeto do tanque experimental, e as Figuras I.2 e I.3, as fotos referentes às etapas de construção. Foi utilizado concreto armado para a fundação do tanque, onde foi colocada uma tela de aço por toda a sua extensão. As paredes são de bloco de concreto, como pode ser observado na Figura I.3.

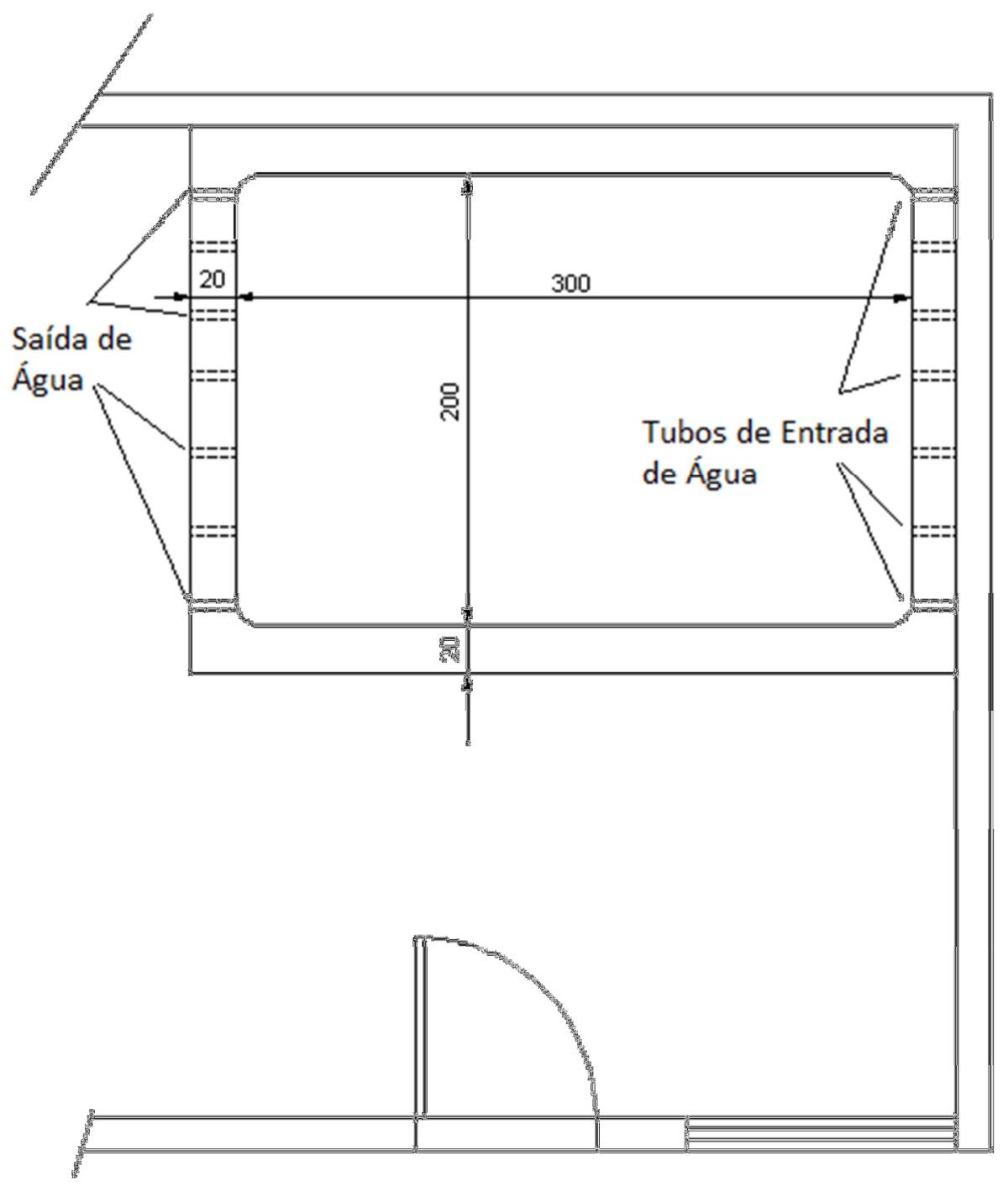

Figura I.1 - Planta do tanque experimental. 


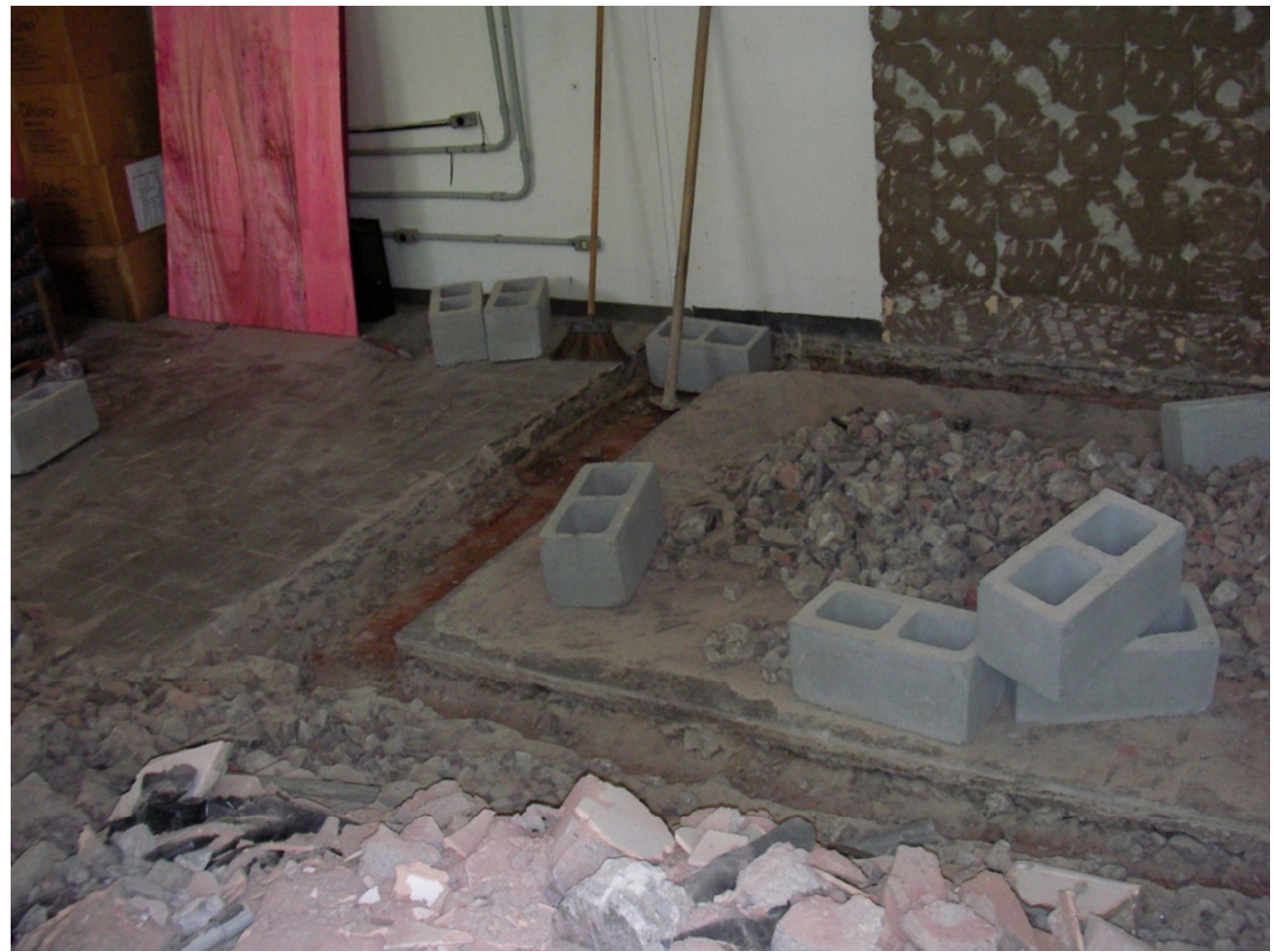

Figura I.2 - Início das obras - escavação da fundação.

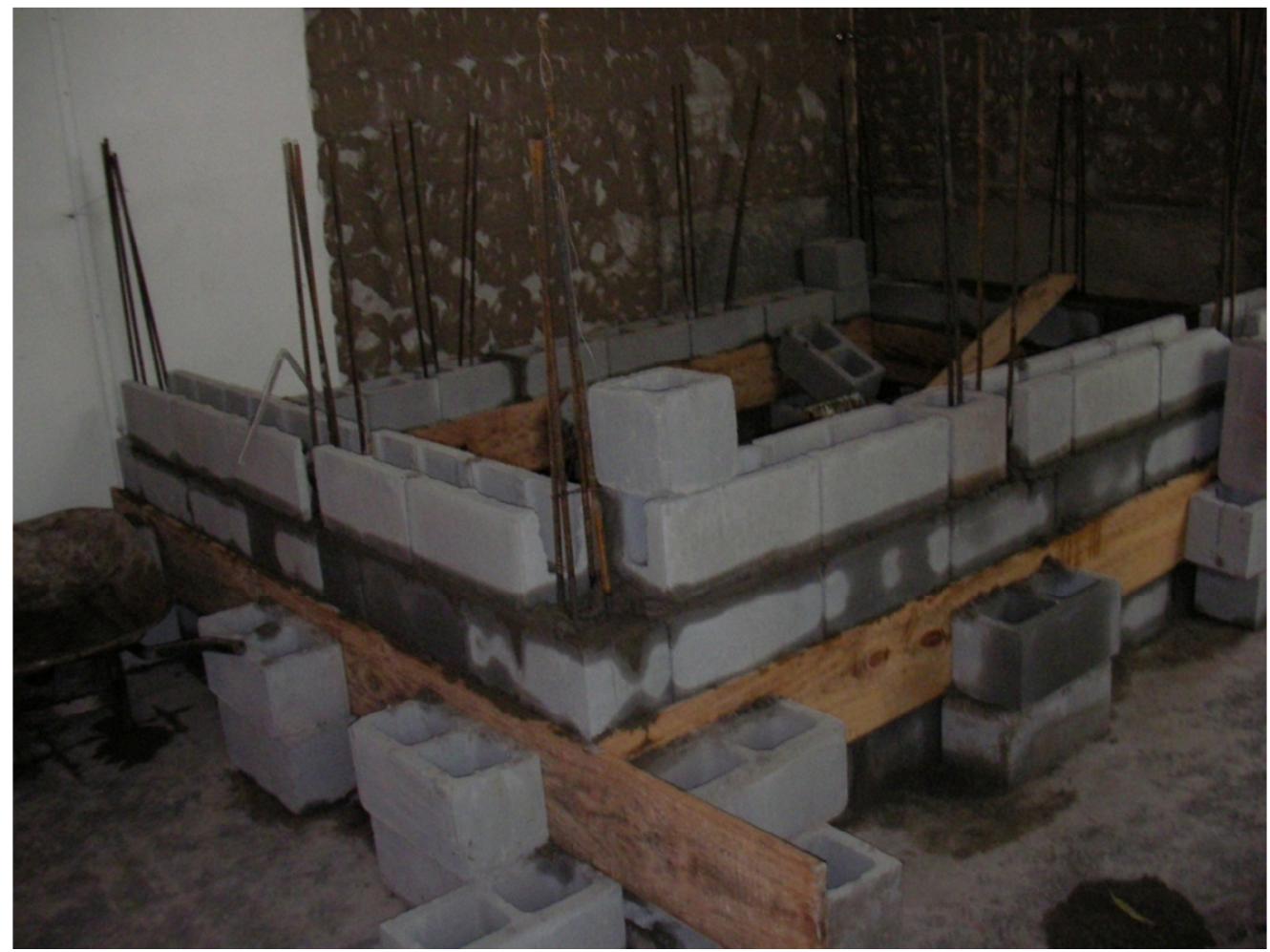

Figura I.3 - Levantamento das fiadas de bloco de concreto.

A cada duas fiada de blocos foi inserida uma vigota com armação, para que o tanque resista à compactação do solo a ser executada no seu interior. 
A Figura I.4 apresenta a parte interna do tanque, onde foi aplicado o impermeabilizante. No fundo do tanque, estão instaladas as entradas e saídas de água.

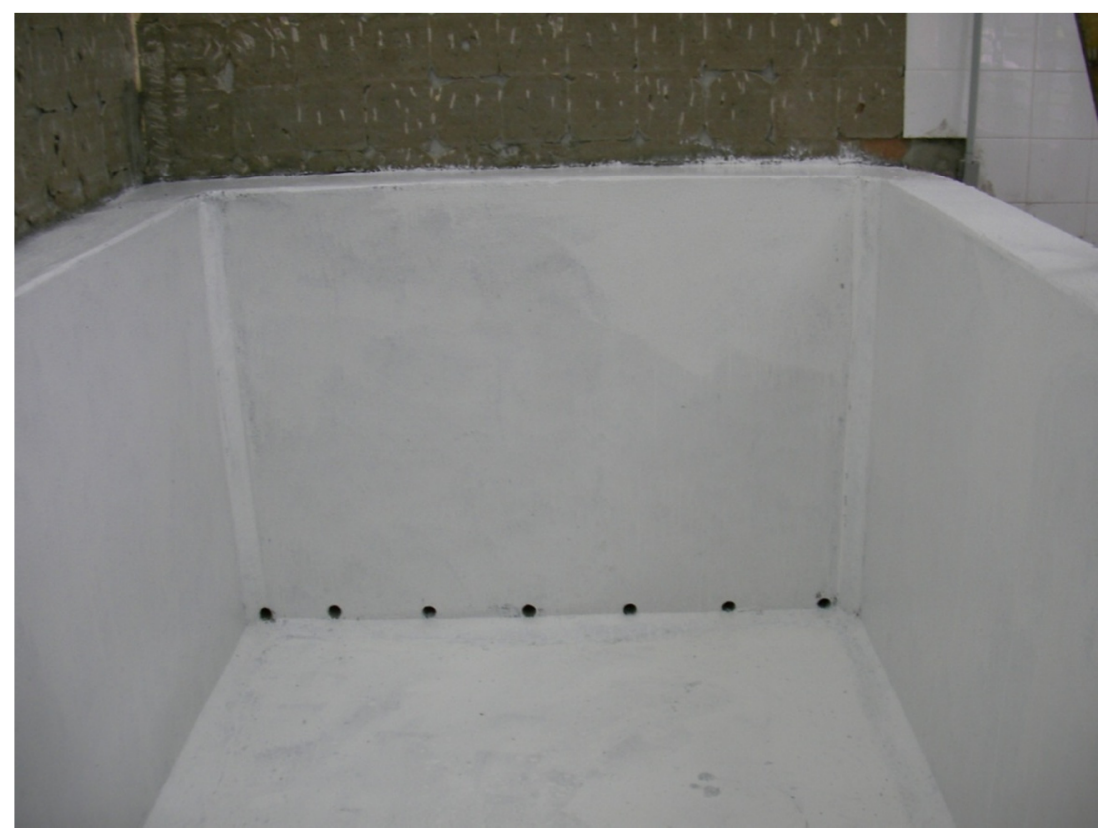

Figura I.4 - Revestimento da parte interna do tanque com material impermeabilizante.

As entradas de água estão localizadas no lado menor. O detalhe da saída de água está mostrada na Figura I.5. Onde foi colocada uma tela para evitar a saída de material pela tubulação. Para controlar o nível da água no tanque experimental, foi instalado um sistema composto por dois reservatórios ligados por tubos, como mostra a Figura I.6. Com os controles do nível d’água de entrada e saída foi possível impor o gradiente desejado para gerar o fluxo de água. 


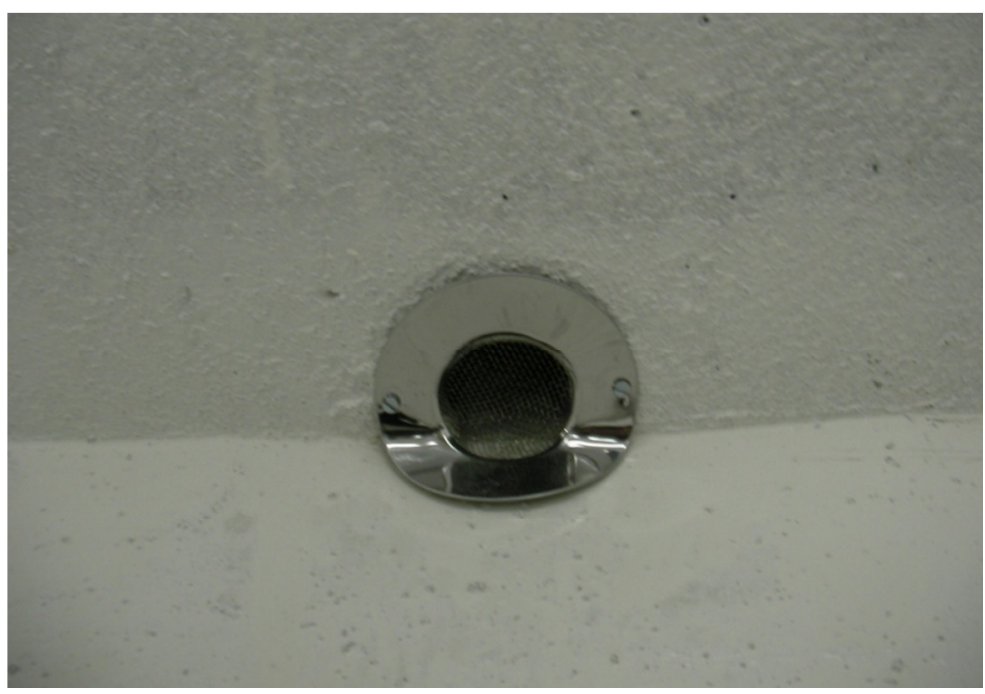

Figura I.5 - Detalhe da saída de água.

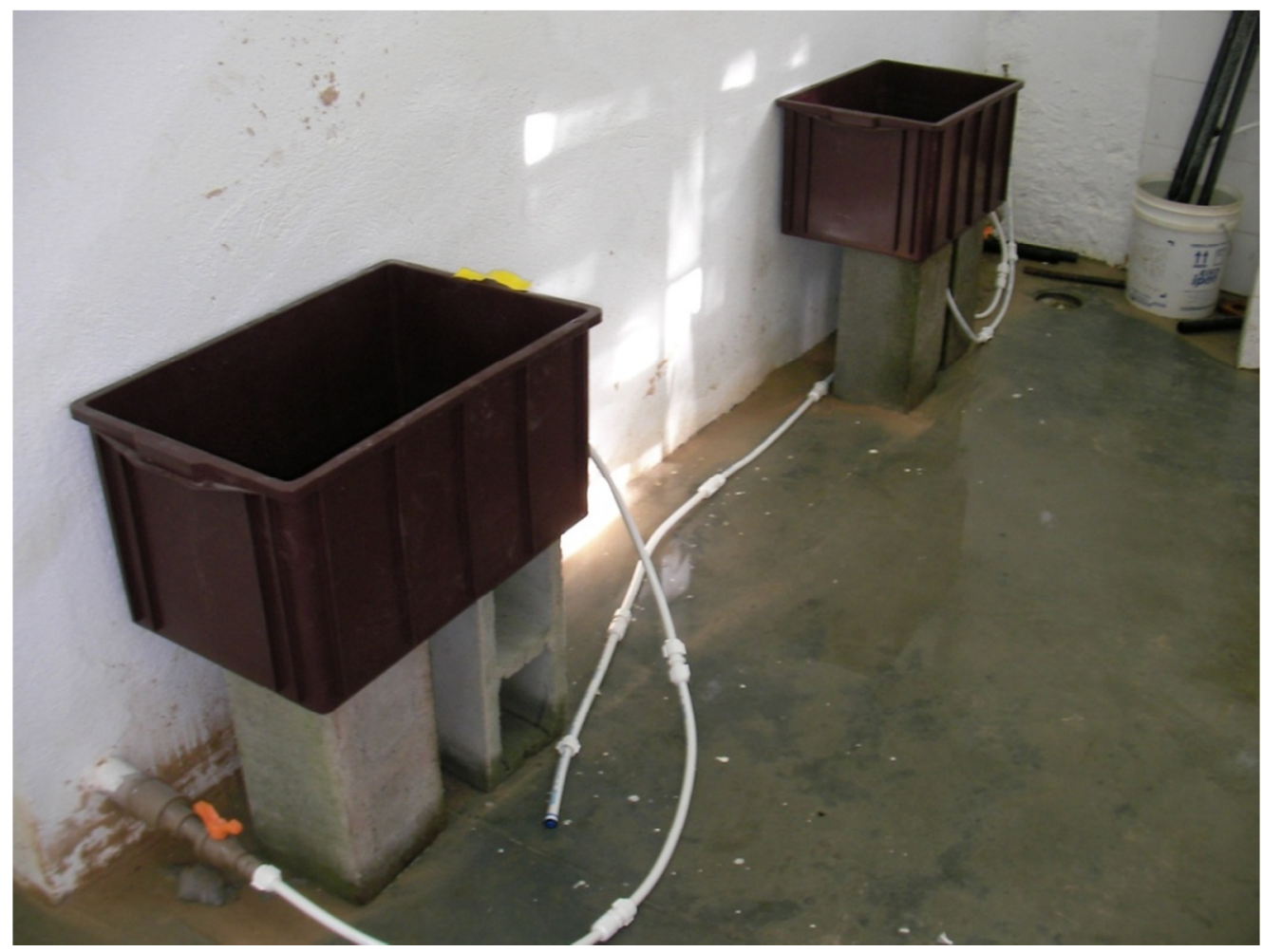

Figura I.6 - Sistema para regular o nível da água.

Para a impermeabilização do tanque, foi utilizada uma camada de reboco com a argamassa misturada com Vedacit e posteriormente revestida com o produto denominado Coberit, provendo impermeabilidade e resistência química ao interior do tanque. 
Anexo II - Sequência de fotos com o horário e profundidade do óleo no tubo guia no primeiro ensaio com o modelo físico.
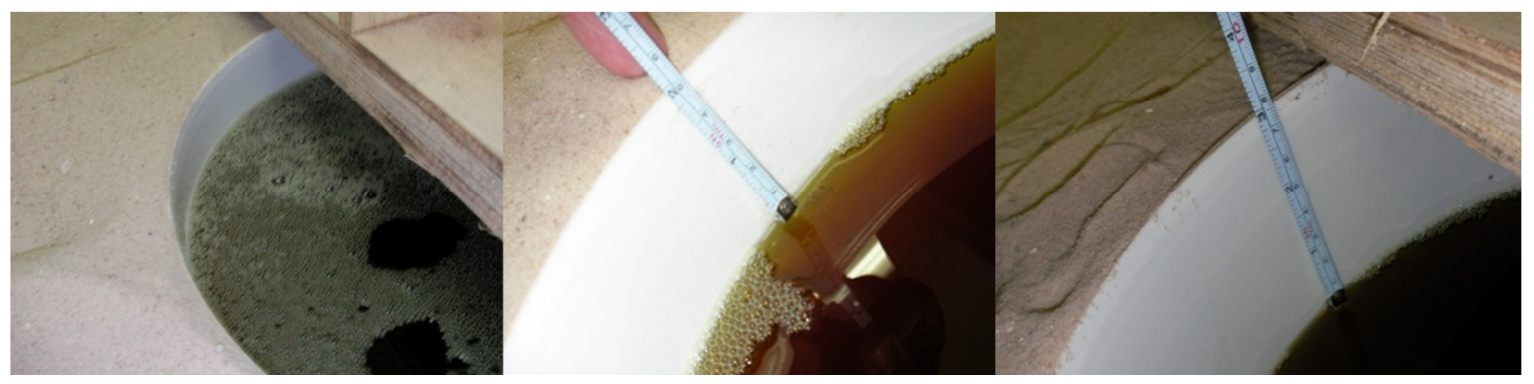

$$
1 \text { minuto }-3 \mathrm{~cm}
$$

4 minutos $-5 \mathrm{~cm}$

6 minutos $-7,6 \mathrm{~cm}$

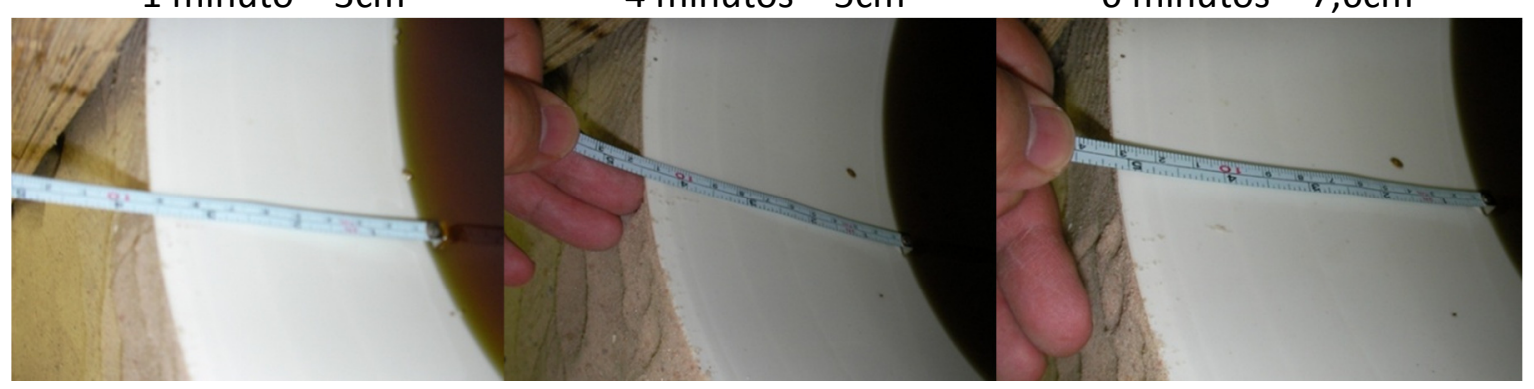

9 minutos $-9,1 \mathrm{~cm}$ 13 minutos $-11,4 \mathrm{~cm}$

17 minutos $-13 \mathrm{~cm}$

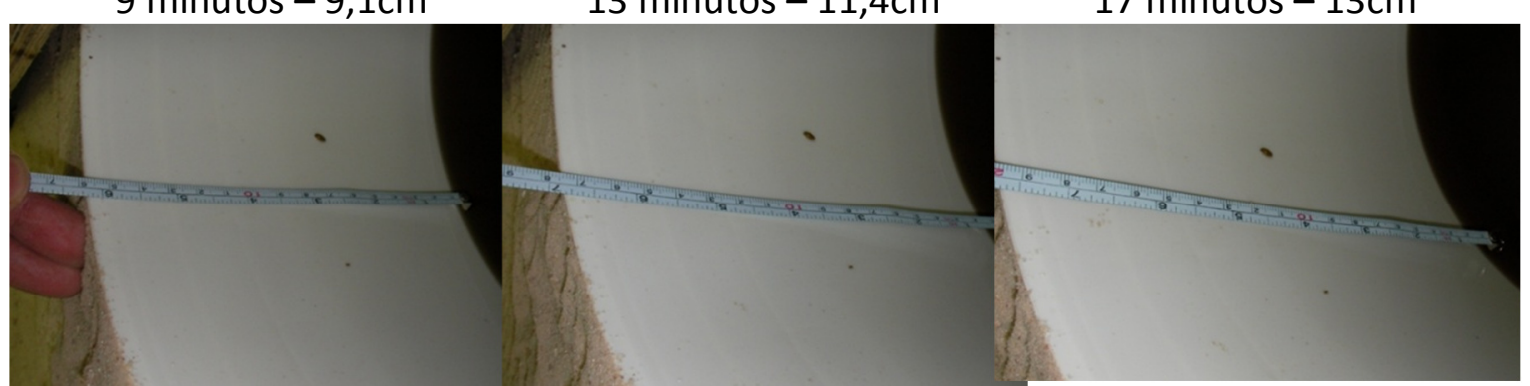

24 minutos $-15,8 \mathrm{~cm}$

28 minutos $-17,4 \mathrm{~cm}$

34 minutos $-20,1 \mathrm{~cm}$

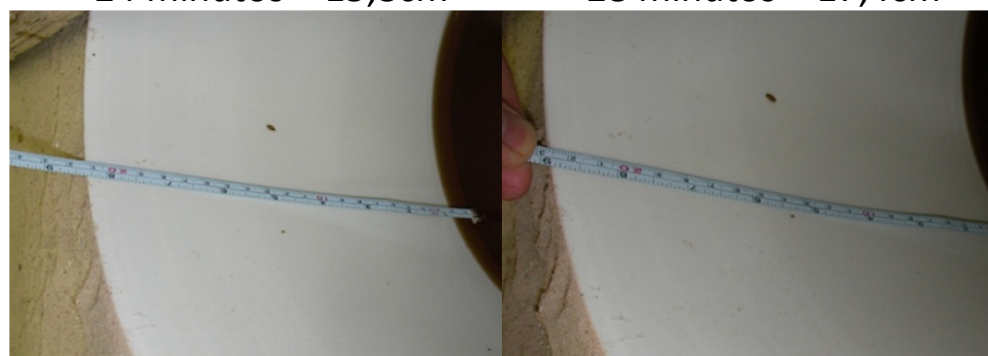

39 minutos $-21,2 \mathrm{~cm}$

44 minutos $-22,5 \mathrm{~cm}$

49 minutos $-23,7 \mathrm{~cm}$
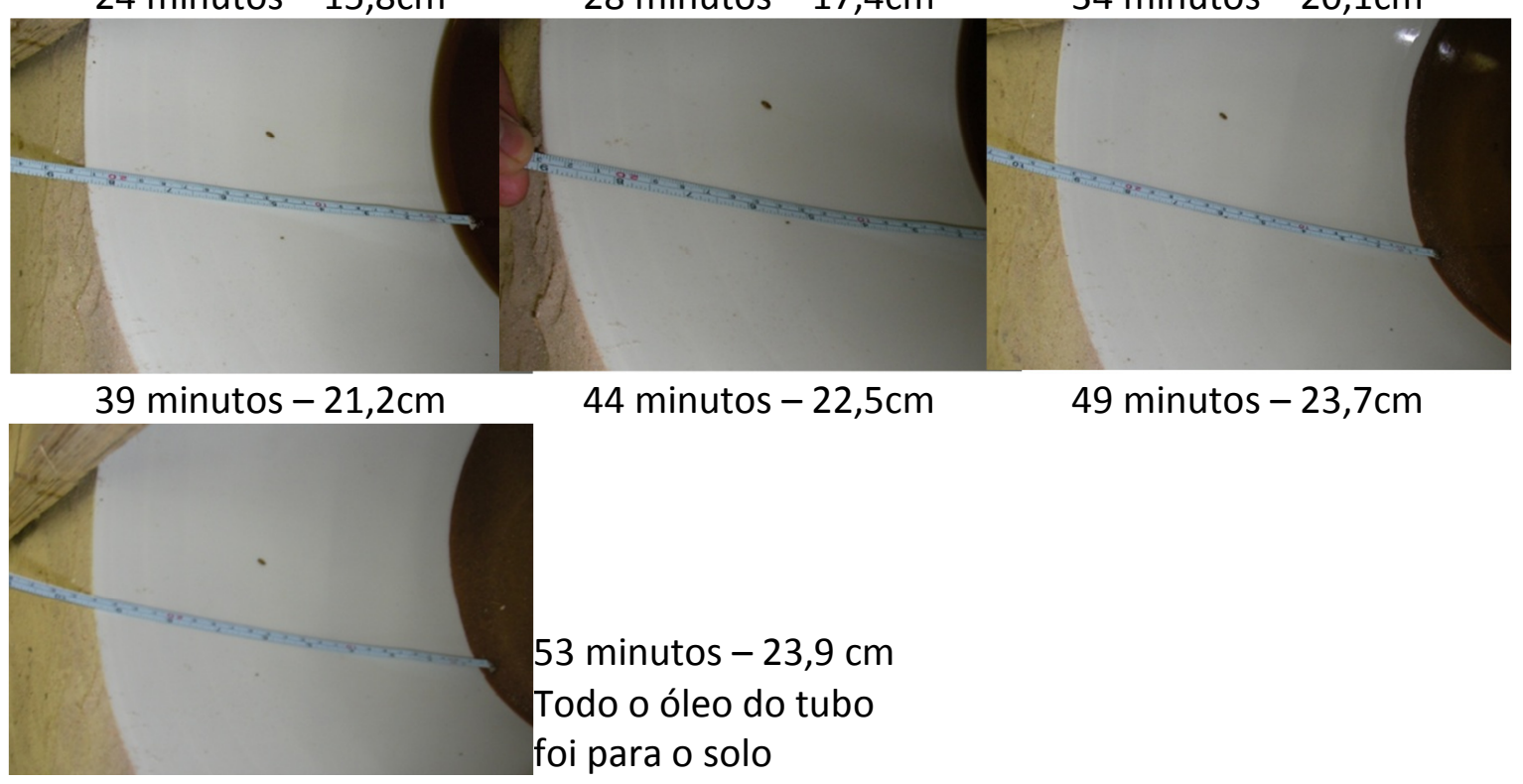